US Army Corps

of Engineers ${ }_{\circledast}$

Engineer Research and

Development Center

\title{
Deconstruction Feasibility Assessment of Warehouse District Facilities at Fort Leonard Wood, Missouri
}

Samuel J. Vance, Thomas A. Carlson, Juan L. Davila-Perez, January 2022 and Dominique S. Gilbert

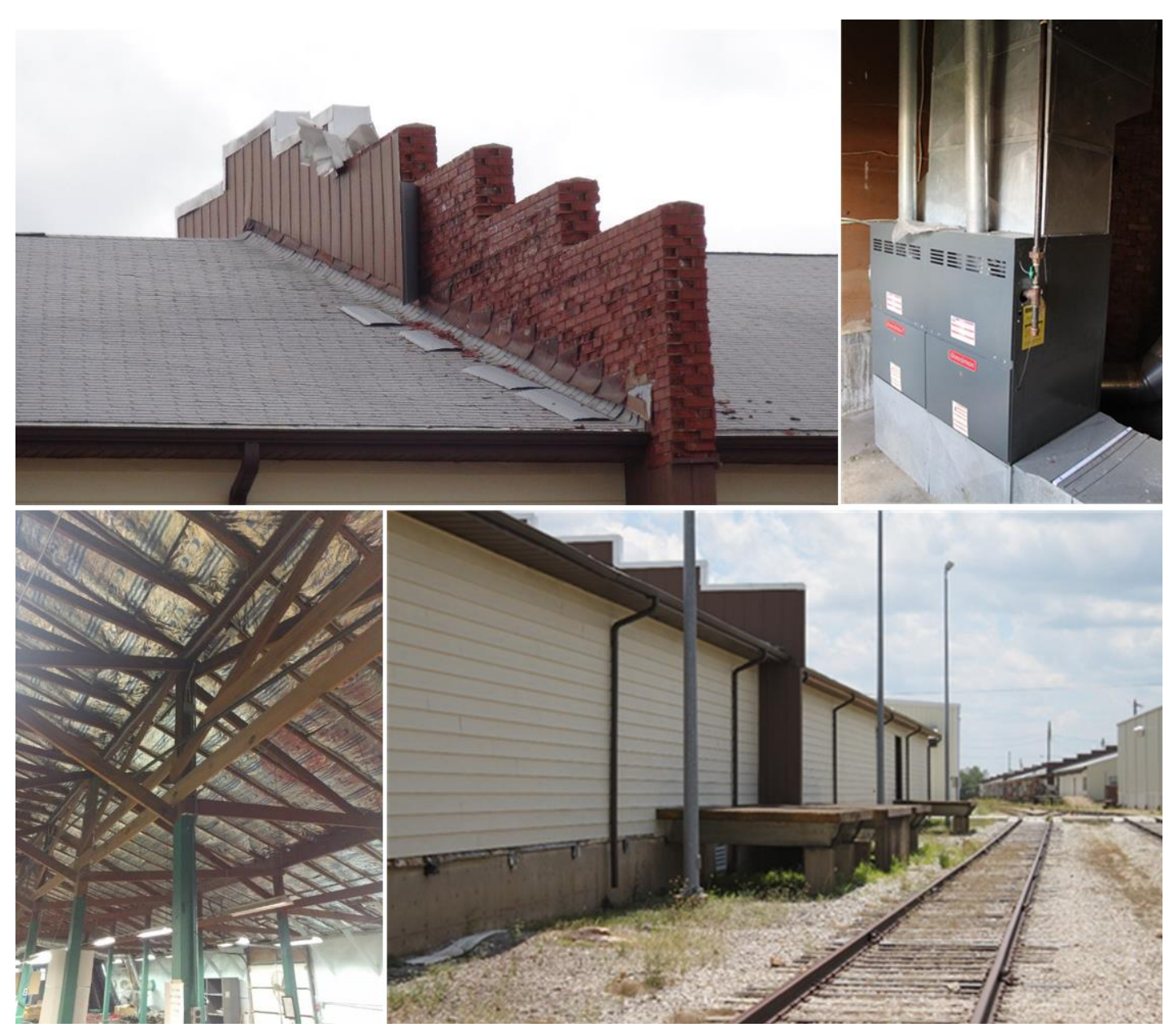


The U.S. Army Engineer Research and Development Center (ERDC) solves the nation's toughest engineering and environmental challenges. ERDC develops innovative solutions in civil and military engineering, geospatial sciences, water resources, and environmental sciences for the Army, the Department of Defense, civilian agencies, and our nation's public good. Find out more at www.erdc.usace.army.mil.

To search for other technical reports published by ERDC, visit the ERDC online library at http://acwc.sdp.sirsi.net/client/default. 


\section{Deconstruction Feasibility Assessment of Warehouse District Facilities at Fort Leonard Wood, Missouri}

Samuel J. Vance, Thomas A. Carlson, Juan L. Davila-Perez, and Dominique S. Gilbert U.S. Army Engineer Research and Development Center (ERDC)

Construction Engineering Research Laboratory (CERL)

2902 Newmark Dr.

Champaign, IL 61822

Final Report

Approved for public release; distribution is unlimited.

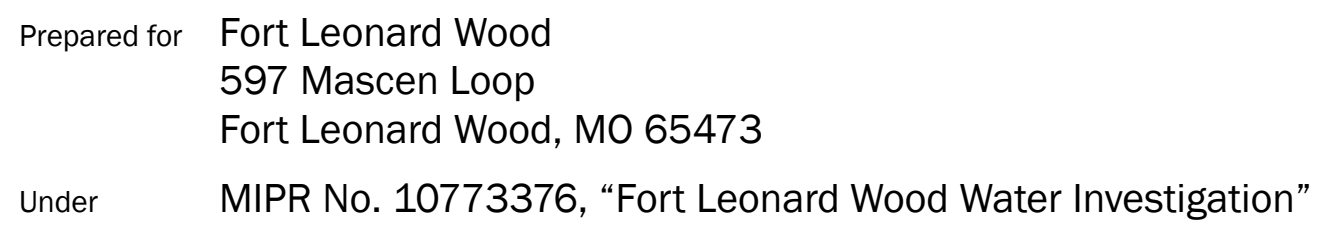




\section{Abstract}

The U.S. Army Engineer Research and Development Center, Construction Engineering Research Laboratory (ERDC-CERL) and Fort Leonard Wood, $\mathrm{MO}$, are in the sixth year of efforts to plan and implement a program in support of installation sustainability. As part of this effort, ERDC-CERL personnel supported the Fort Leonard Wood Directorate of Public Works (DPW) by conducting a deconstruction assessment of multiple buildings in the warehouse district. The project delivery team visited Fort Leonard Wood in April 2017 to conduct quantity take-offs of the buildings. An abbreviated interim report that focused exclusively on Bldgs. 2338 and 2339 was provided to the Chief, Master Planning Branch, at that time. These two buildings were representative of the majority of the buildings in the assessment and thus became the model that we describe in detail in the sections below. Differences between the other warehouses and the model are discussed. Several buildings that had configurations different from that of the model were evaluated independently.

DISCLAIMER: The contents of this report are not to be used for advertising, publication, or promotional purposes. Citation of trade names does not constitute an official endorsement or approval of the use of such commercial products. All product names and trademarks cited are the property of their respective owners. The findings of this report are not to be construed as an official Department of the Army position unless so designated by other authorized documents. 


\section{Contents}

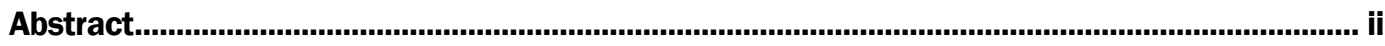

Figures and Tables.....................................................................................................................................

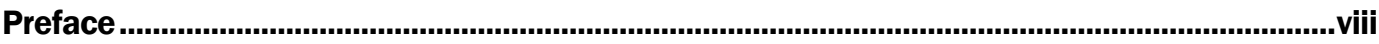

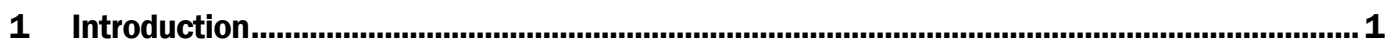

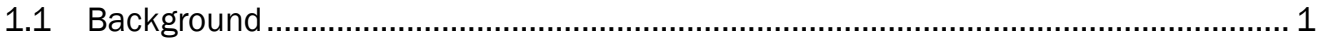

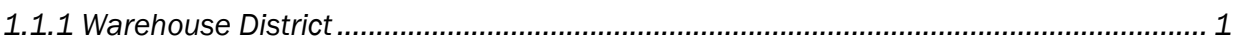

1.1.2 General warehouse construction ............................................................................ 1

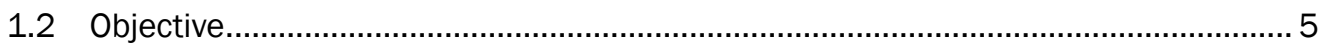

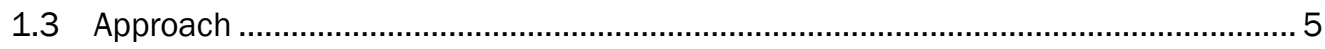

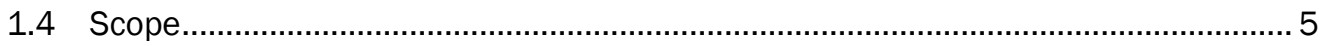

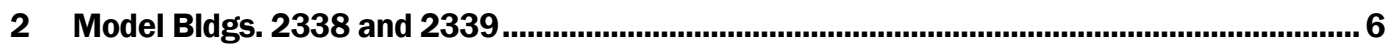

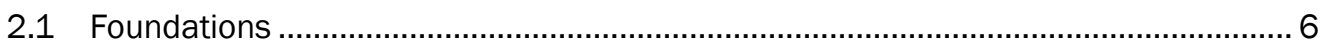

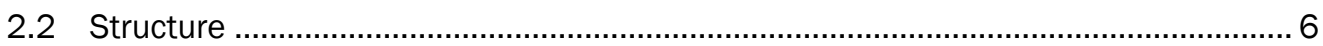

2.3 Exterior enclosure ................................................................................................. 8

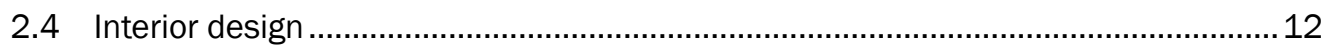

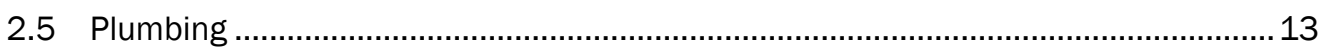

2.6 Mechanical ..................................................................................................... 13

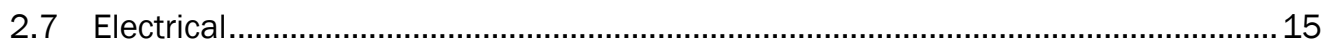

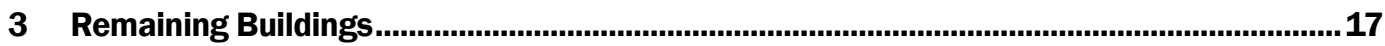

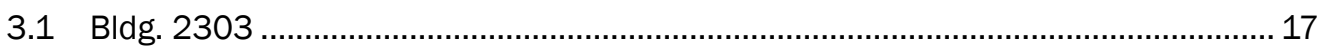

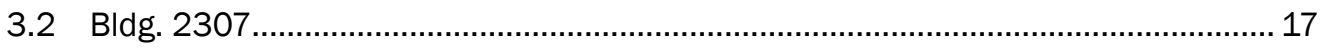

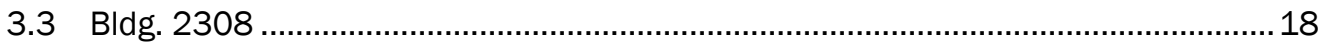

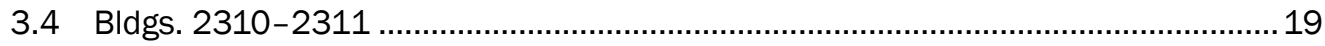

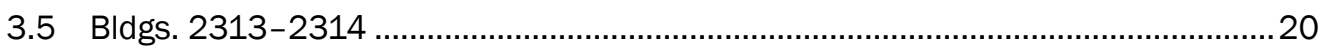

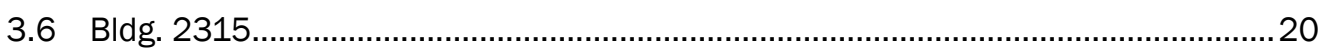

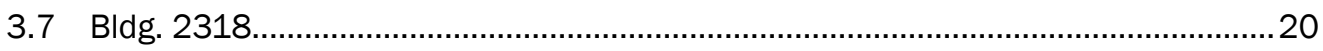

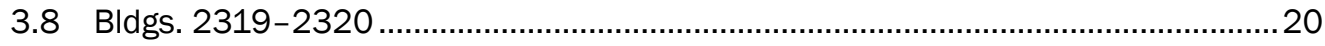

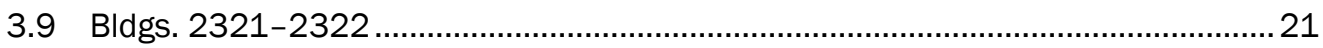

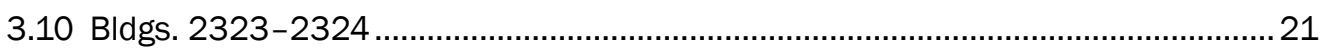

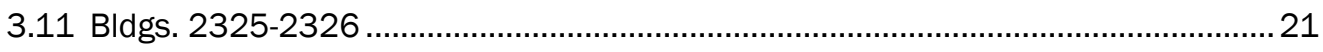

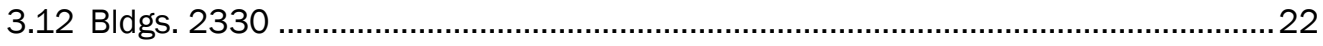

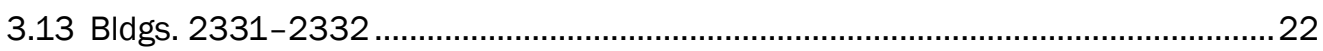

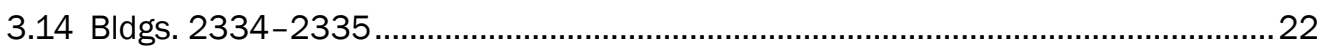

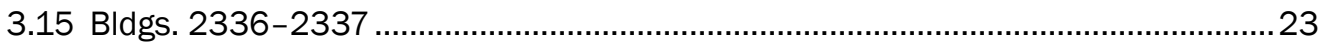

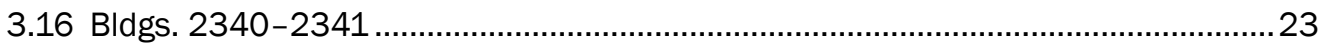

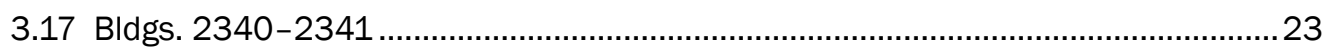

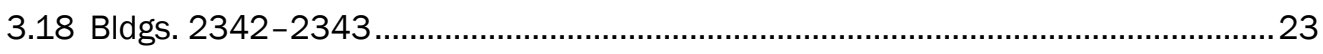

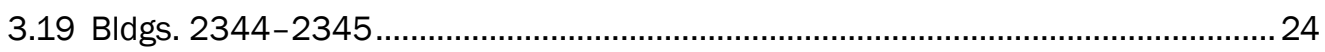




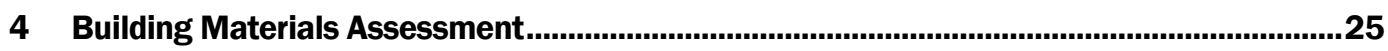

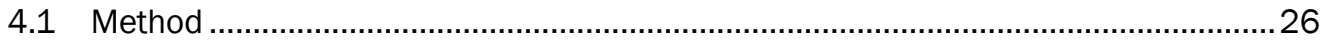

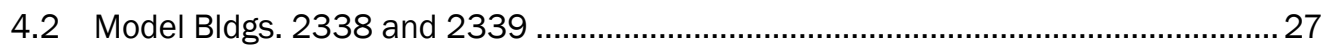

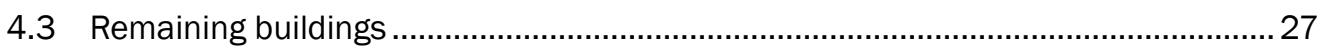

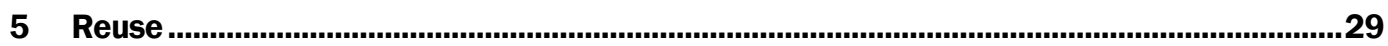

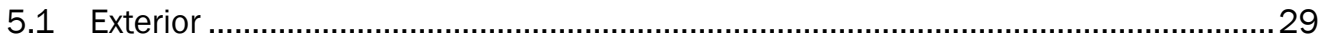

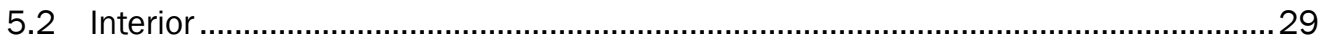

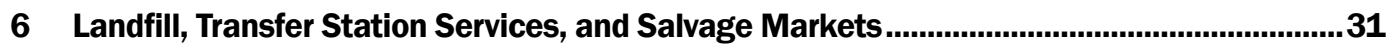

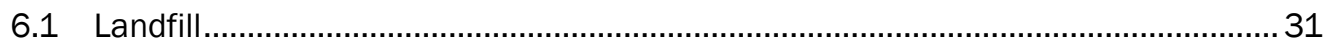

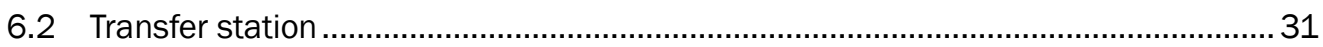

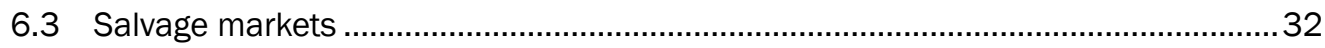

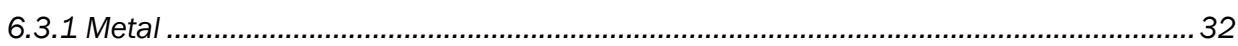

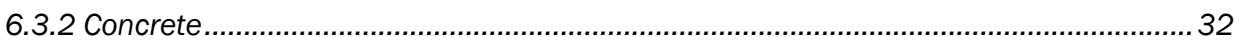

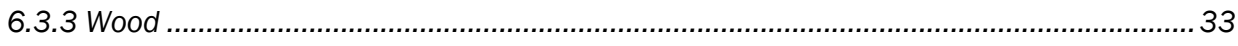

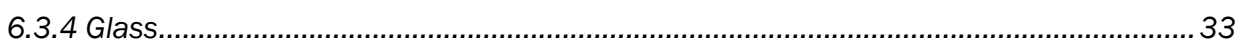

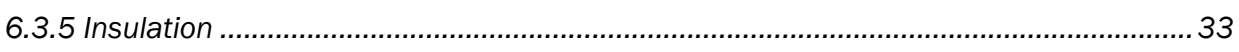

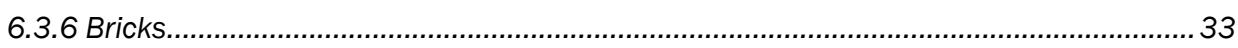

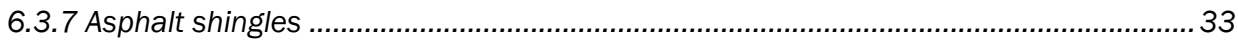

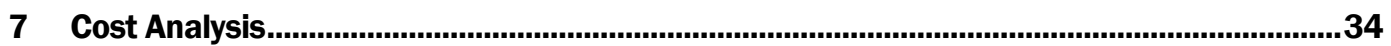

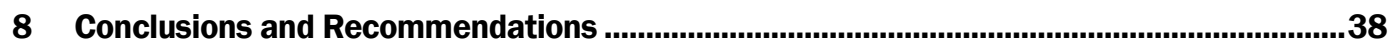

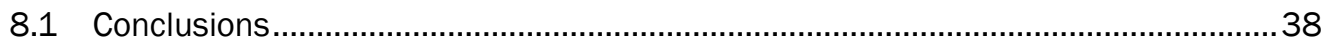

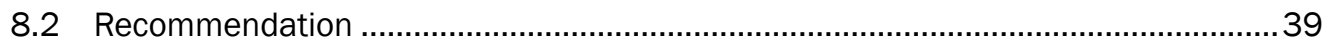

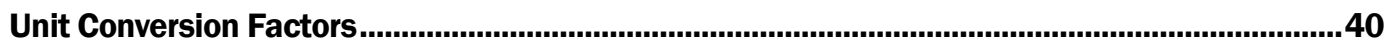

Appendix A: Detailed Assessment of Bldgs. 2310-2311...........................................................

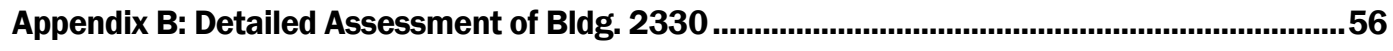

Appendix C: Detailed Assessment of Bldg. $2332 \ldots$

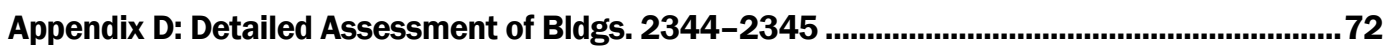

Report Documentation Page (Standard Form 298)....................................................................85 


\section{Figures and Tables}

\section{Figures}

1 Fort Leonard Wood Warehouse District: Selected buildings for the deconstruction assessment are outlined in red. (Map data: Google,

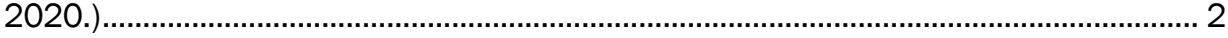

2 Fort Leonard Wood Warehouse District showing building numbers ............................... 3

3 Warehouse showing typical windows, doors, air-conditioning $(\mathrm{A} / \mathrm{C})$ units, and concrete ramps ................................................................................................ 4

$4 \quad$ Railroad tracks adjacent to many of the warehouses ....................................................... 4

$5 \quad$ Covered walkways between adjacent warehouses......................................................... 5

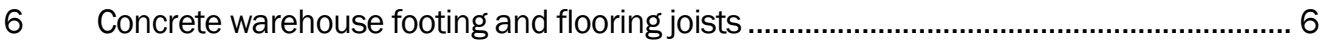

$7 \quad$ Sign indicating warehouse floor load limit .................................................................. 7

8 Typical wooden warehouse ceiling truss structure .............................................................. 7

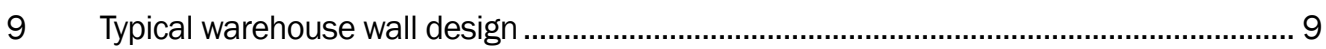

10 Wall between the warehouse and office space............................................................. 9

11 Brick firewall above the roof was covered with siding until damaged from

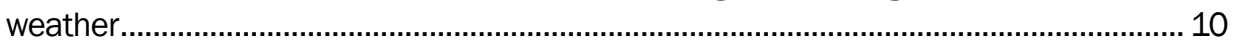

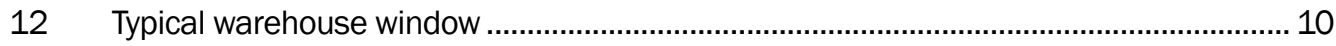

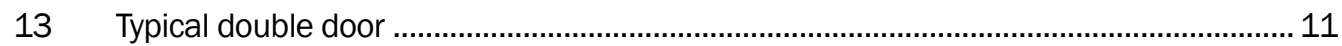

14 Large sliding corrugated door separating two adjacent warehouse

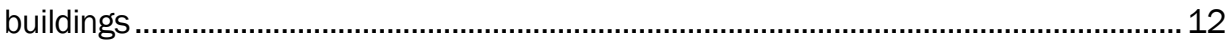

15 Typical warehouse floor, finished hardwood slats ....................................................... 13

16 Typical warehouse restroom facility: toilet, urinal, and sink .......................................... 14

17 Typical drinking fountain ...................................................................................... 14

18 Typical furnace for office spaces and restroom facilities ........................................... 14

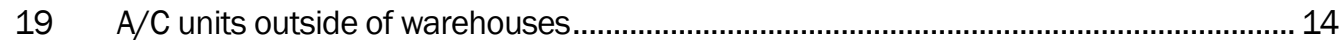

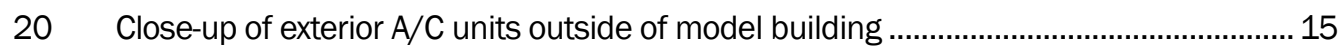

21 Ceiling-mounted fan coil unit in main warehouse area ................................................. 15

22 Typical fluorescent lighting in warehouse area.............................................................. 16

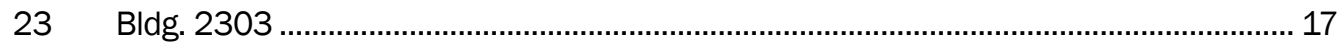

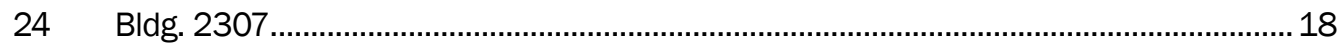

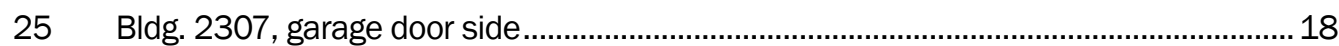

26 Bldg. 2308, lengthwise view ......................................................................................... 19

27 Bldg. 2308, view of wall and ceiling …………........................................................... 19

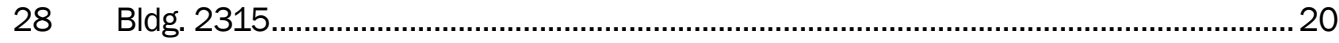

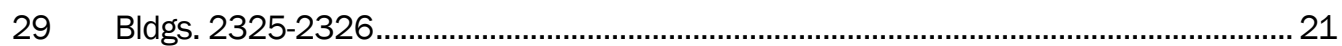

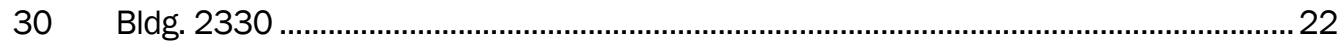

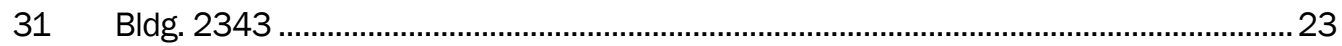

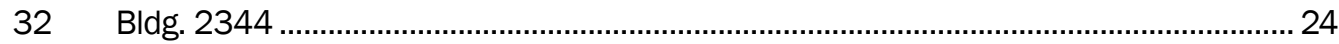

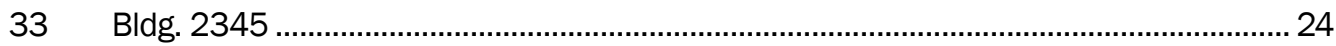




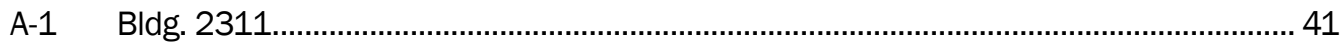

A-2 Bldg. 2311, showing proximity to railroad tracks ........................................................ 42

A-3 Wooden deck on the front side of (warehouse) Bldgs. 2310 and 2311......................... 42

A-4 Labeled load limit of Bldgs. 2310 and 2311 floor ......................................................... 43

A-5 Structural wood available for recovery .................................................................... 44

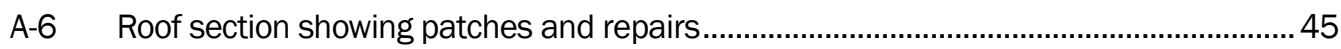

A-7 Single exterior door, in good condition ............................................................................ 46

A-8 Corrugated metal doors on either side of the fire wall ...................................................... 47

A-9 Flooring with sporadic gouges in high traffic areas ..................................................... 48

A-10 Flooring in serviceable condition that can be reclaimed................................................. 48

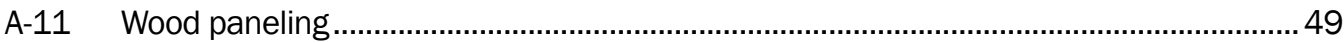

A-12 Bathroom sink console ............................................................................................. 49

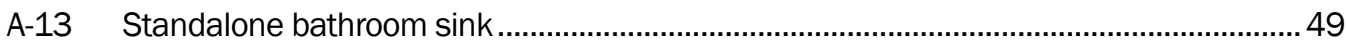

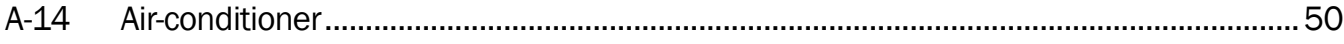

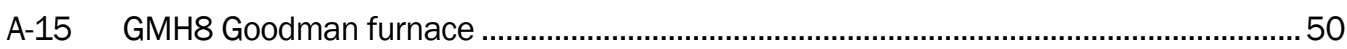

A-16 Ck24-18 Goodman furnace......................................................................................... 51

A-17 Industrial ceiling-hung 4 ft, 2-tube fixtures ............................................................... 52

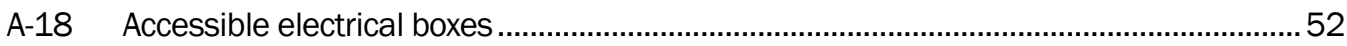

A-19 Pipe network for the sprinklers …….................................................................. 53

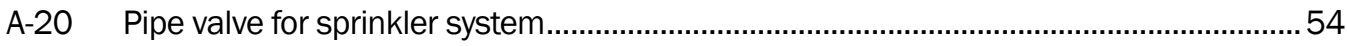

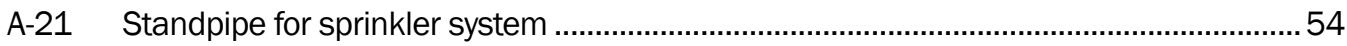

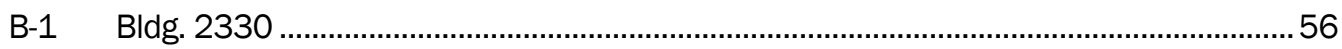

B-2 Loading docks on the back side of the warehouse that are no longer in

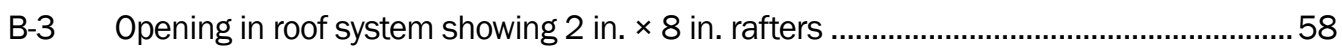

B-4 Opening in roof system showing braced rafters ........................................................... 59

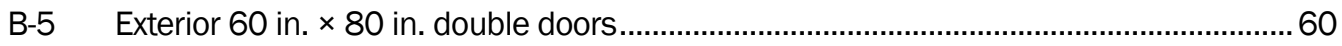

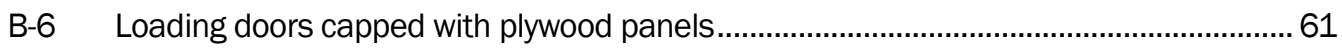

B-7 Heavily worn flooring in Bldg. 2330 .................................................................... 62

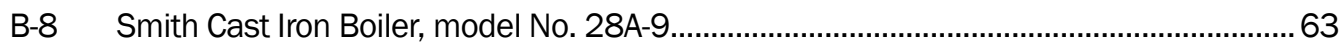

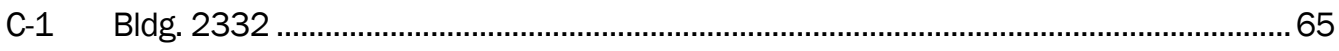

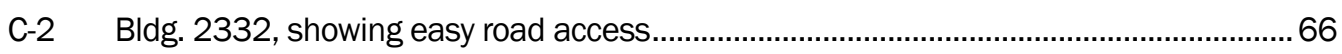

C-3 Bldg. 2332 roof system, rafters spanning the ridge to the exterior walls .........................67

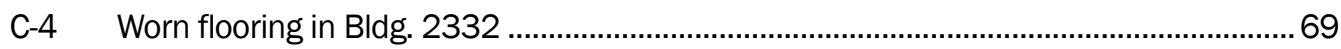

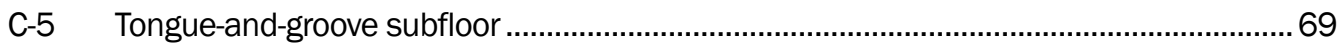

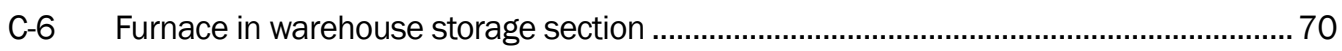

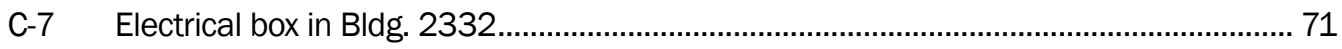

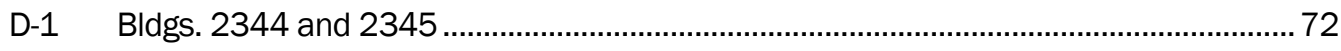

D-2 Bldgs. 2344 and 2345, showing proximity to railroad tracks...................................... 73

D-3 Disused loading docks on the back side of the Bldgs. 2344 and 2345 (warehouse). 
D-4 Bldgs. 2344 and 2345 wooden roofing system..................................................... 75

D-5 Bldgs. 2344 and 2345 roofing system, lengthwise view ............................................. 75

D-6 Overhead metal door in Bldg. 2345 ………....................................................... 77

D-7 Large corrugated metal doors on either side of the fire wall in Bldg. 2345 .................... 78

D-8 Flooring in Bldg. 2345 showing diagonal maple boards .................................................... 78

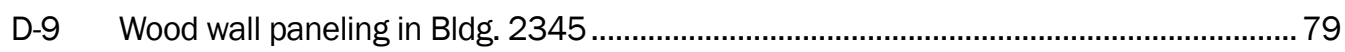

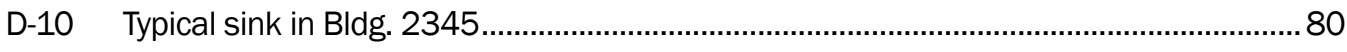

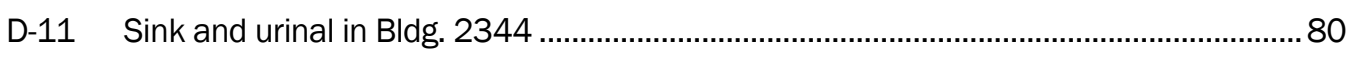

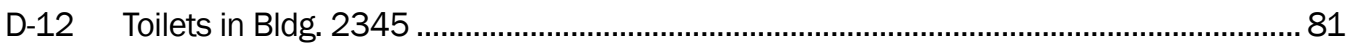

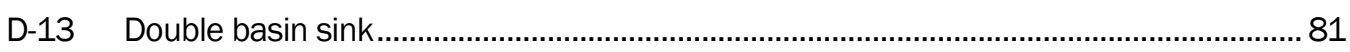

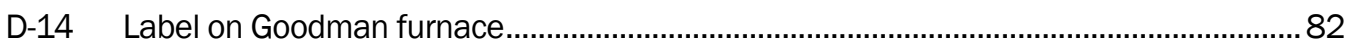

D-15 Furnace in Bldg. 2344 mechanical room ................................................................... 82

D-16 Water heater for sinks in Bldg. 2344 .................................................................. 82

D-17 Electrical paneling and boxes in Bldg. 2310

\section{Tables}

$1 \quad$ Estimated material quantities for the model Bldgs. 2338 and 2339............................ 25

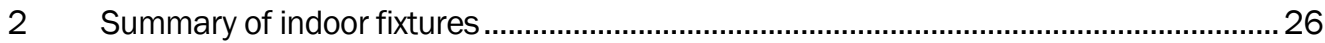

3 Summary of exterior building elements for all warehouses.......................................... 27

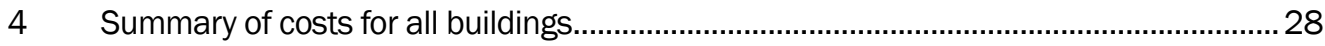

5 Contacts for various entities accepting the materials generated during deconstruction ......................................................................................................... 32

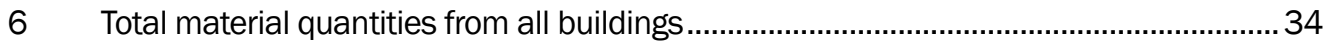

$7 \quad$ Revenue from salvageable materials ....................................................................... 35

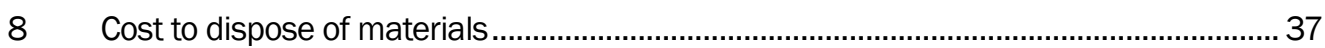

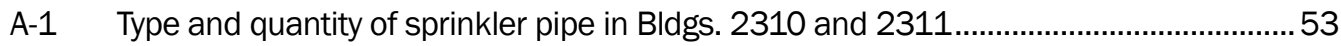




\section{Preface}

This study was conducted for Fort Leonard Wood, MO, under Military Interdepartmental Purchase Request (MIPR) No. 10773376, "Fort Leonard Wood Water Investigation," Project A1090, "Net Zero Water." The technical monitor was Mark Premont, Plans Administration and Integration Office, Fort Leonard Wood, MO.

The work was managed and executed by the Engineering Process Branch and the Energy Branch, of the Facilities Division, Construction Engineering Research Laboratory, Engineer Research and Development Center (ERDC-CERL). At the time of publication, the Chief of the Engineering Processes Branch was Mr. Charles G. Schroeder, the Chief of the Energy Branch was Mr. Jedediah B. Alvey, the Chief of the Facilities Division was Ms. Gisselle Rodriguez, and the Technical Director for Installations was Mr. James P. Allen. The Deputy Director of ERDC-CERL was Ms. Michelle J. Hanson, and the Director was Dr. Andrew J. Nelson.

COL Teresa A. Schlosser was Commander of ERDC, and Dr. David W. Pittman was the Director. 


\section{Introduction}

\subsection{Background}

Engineer Research and Development Center, Construction Engineering Research Laboratory (ERDC-CERL) personnel are supporting the Fort Leonard Wood Directorate of Public Works (DPW) by conducting a deconstruction assessment of multiple buildings in the warehouse district. Members of the project delivery team visited Fort Leonard Wood in April 2017 to conduct quantity take-offs of the respective buildings. An abbreviated interim report that focused exclusively on Bldgs. 2338 and 2339 was provided to the Chief, Master Planning Branch, at that time. Because these two buildings are representative of the majority of the buildings in the assessment, they became the model described in detail in the following sections. The following sections also discuss differences between some of the other warehouses and the model. Bldgs. 2303, 2307, and 2308 had configurations different from that of the model and were evaluated independently. Figure 1 shows the entire scope of buildings assessed in the project.

\subsubsection{Warehouse District}

Figure 2 shows the building number designations for all units in the Warehouse District. The elevation of this area is constant (flat ground), and all buildings are located near adjacent roads, which would provide ease of deconstruction. However, because of the close proximity of neighboring buildings, care will need be taken by the contractor to protect adjacent facilities that are not to be deconstructed/demolished at that time.

\subsubsection{General warehouse construction}

The assessment area includes several general purpose warehouses used for troop material distribution. The wood constructed buildings are contiguous and are divided by brick veneered fire walls. Each building is $152 \mathrm{ft}$ long and $60 \mathrm{ft}$ wide, resulting in an area of 9,240 $\mathrm{ft}^{2}$. The dimensions and configuration of these buildings is common to the majority of buildings in the warehouse district (Figure 3). 
Figure 1. Fort Leonard Wood Warehouse District: Selected buildings for the deconstruction assessment are outlined in red. (Map data: Google, 2020.)

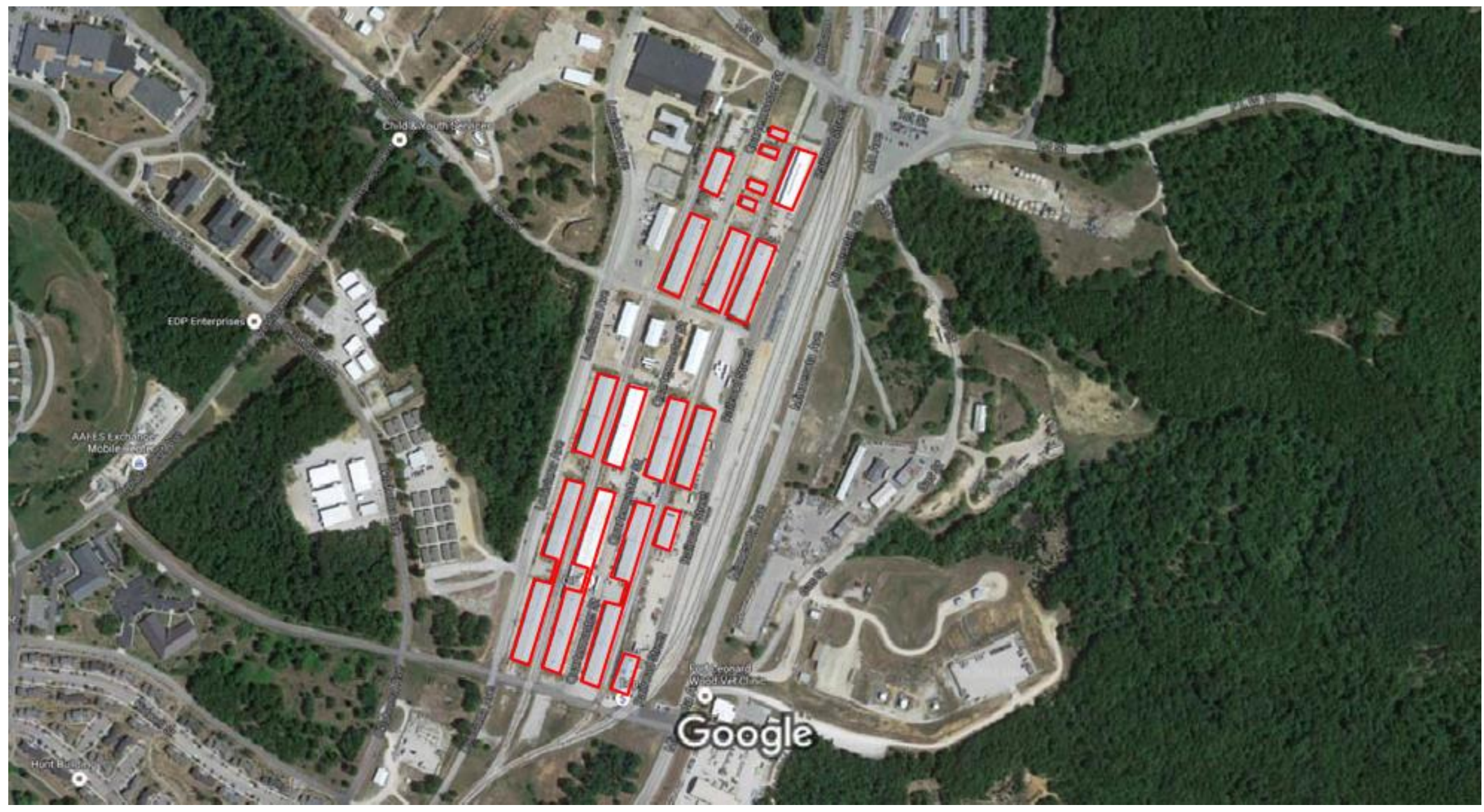


Figure 2. Fort Leonard Wood Warehouse District showing building numbers.

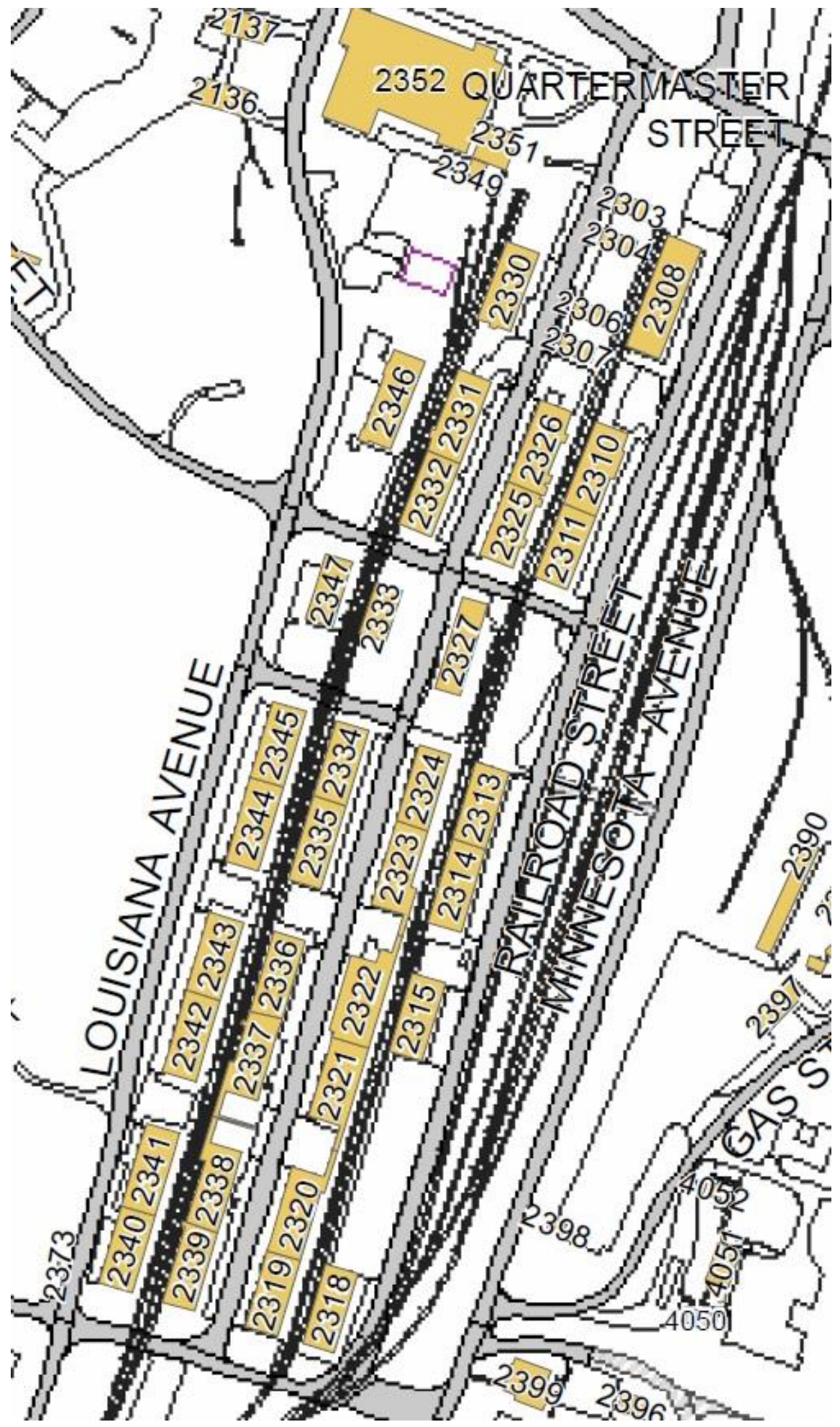


Figure 3. Warehouse showing typical windows, doors, air-conditioning $(A / C)$ units, and concrete ramps.

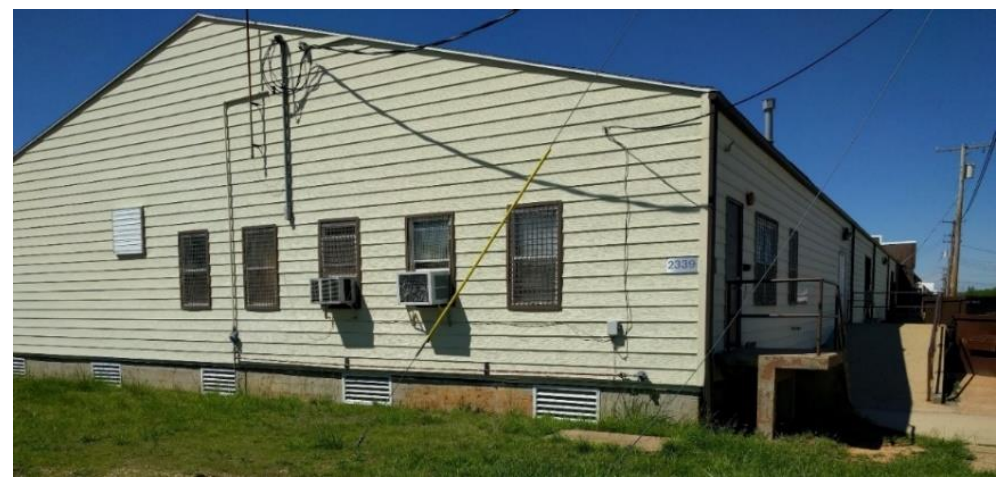

The warehouse buildings generally all have the same interior layout. Small areas of office space having been constructed at the north and south ends of the building, which include adjacent restroom facilities. Each warehouse has a different number of doors, windows, and heating, ventilating, and air-conditioning (HVAC) units. On the exterior, both window and ground air-conditioning $(\mathrm{A} / \mathrm{C})$ units were seen. On the inside, ceilingmounted heating fan coil units were seen.

Some warehouse facilities have elevated walkways adjacent to railroad tracks (Figure 4), some of which also have pitched pedestrian walkway coverings (Figure 5). The walkways are composed of recyclable materials (concrete and steel). These elevated walkways generally connect two adjacent buildings that are not otherwise already joined. Their length and width are consistent for all these structures.

Figure 4. Railroad tracks adjacent to many of the warehouses.

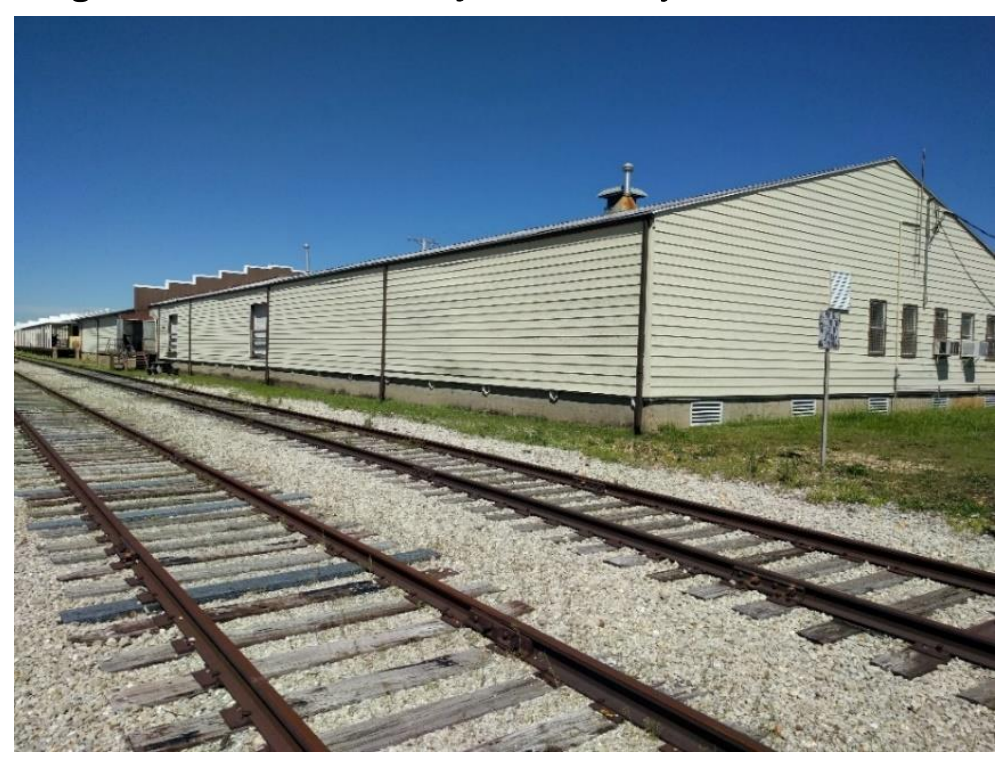


Figure 5. Covered walkways between adjacent warehouses.

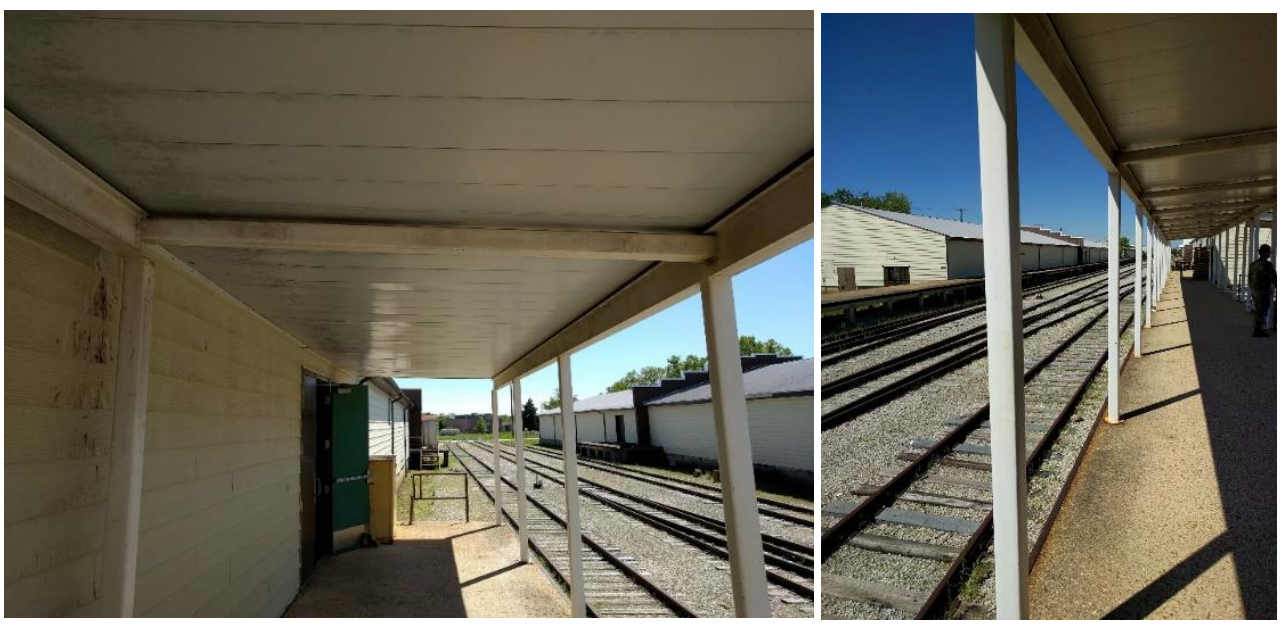

\subsection{Objective}

The objective of this work was to assess representative buildings in the Warehouse District at Fort Leonard Wood, Missouri to determine the feasibility of deconstruction as an alternative to demolition.

\subsection{Approach}

ERDC-CERL personnel conducted a deconstruction assessment of multiple buildings in the Warehouse District by

1. Visiting Fort Leonard Wood in April 2017 to conduct quantity take-offs of the buildings,

2. Providing an interim report that focused exclusively on Bldgs. 2338 and 2339 to the Chief, Master Planning Branch,

3. Using these buildings as a model to evaluating other buildings in the Warehouse District, and

4. Accommodating differences between other warehouses and the model by evaluating those facilities independently.

\subsection{Scope}

Although this project focused on the Warehouse District at Fort Leonard Wood, Missouri, this work could be replicated elsewhere by considering unique aspects of each installation's building facilities. 


\section{Model Bldgs. 2338 and 2339}

\subsection{Foundations}

The foundations of Bldgs. 2338 and 2339 consist of five continuous footings running along the length of the facilities and a continuous footing at each end. The footings are $12 \mathrm{in}$. thick by $16 \mathrm{in}$. wide and the width of the walls of the footings is $8 \mathrm{in}$. The foundation walls are relatively tall to allow for finished floor elevation at railroad train car elevation. The footing depth is assumed to be at the frost depth (24-36 in.).

\subsection{Structure}

The floor systems of Bldgs. 2338 and 2339 consist of $2 \mathrm{ft} \times 12 \mathrm{ft}$ joists spaced $12 \mathrm{in}$. on center spanning the foundation walls (Figure 6). The joists bear on 2 in. $\times 6$ in. sill plates, and 2 in. $\times 12$ in. band joists run the length of the building at the exterior walls. The floor deck was observable from the crawlspace. The construction of the floor system is conducive to equipment operation during deconstruction; construction details reported on a placard in an identical building indicate that the floor is designed to support $150 \mathrm{lb} / \mathrm{ft}^{2}$ (Figure 7 ).

Figure 6. Concrete warehouse footing and flooring joists.

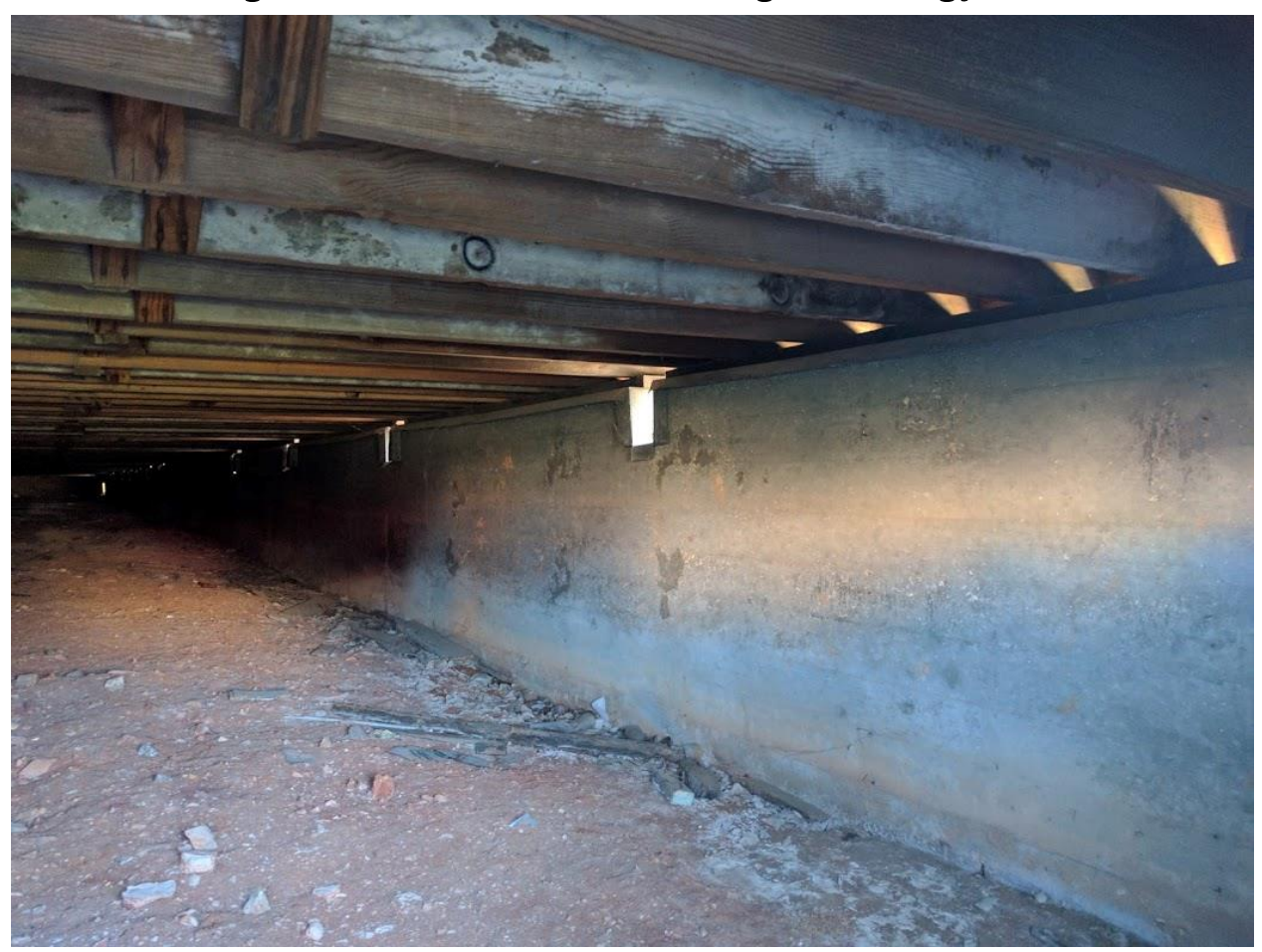


Figure 7. Sign indicating warehouse floor load limit.

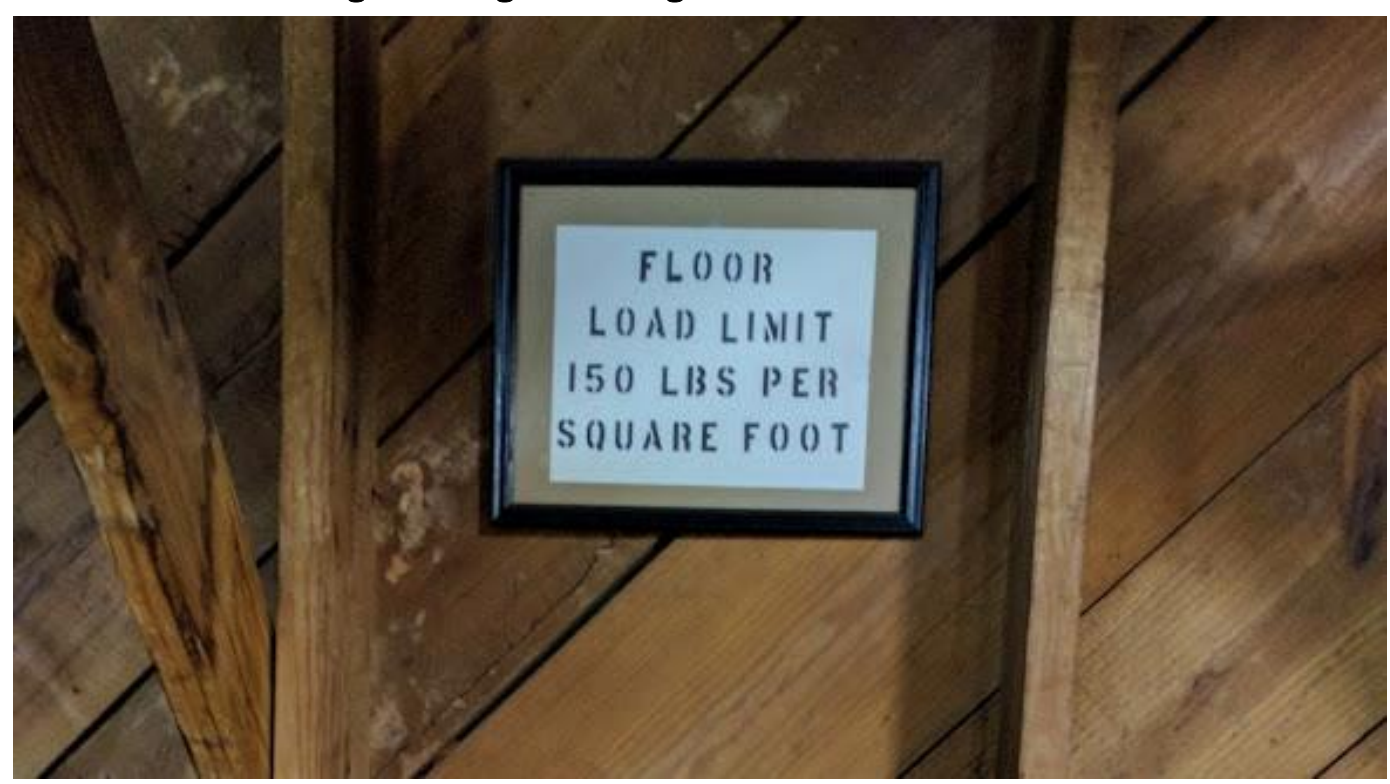

Figure 8. Typical wooden warehouse ceiling truss structure.

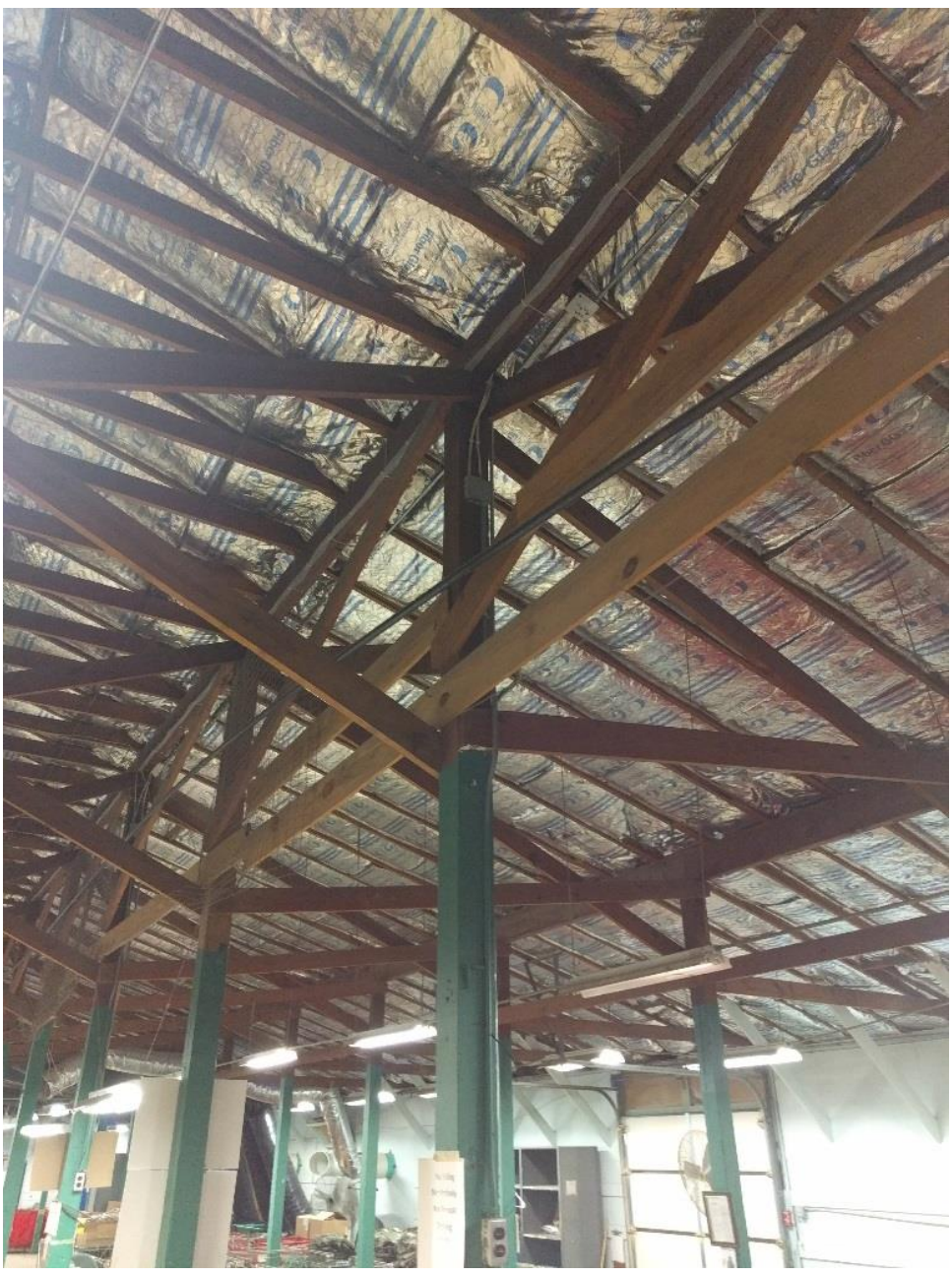


Vertical loads are supported by 6 in. $\times 6$ in. columns on a $9 \mathrm{ft} \times 12 \mathrm{ft}$ grid. Columns are braced both laterally and longitudinally by 2 in. $\times 6$ in. braces of varying lengths. Columns carry two $2 \times 12 \mathrm{~s}$ at each row that run the length of the building. Figure 8 shows the general configuration. Connections are nailed, not bolted.

The roof system is comprised of 2 in. $\times 8$ in. rafters on 24 in. spacing spanning the ridge to the exterior walls. Chicken wire appears to have been installed after initial construction, possibly to contain sloughing insulation or other debris. Roof decking consists of 8 in. wide boards installed perpendicular to the rafters.

The interior of the walls consists of wood studs, sometimes faced with insulation and wallboard (Figure 9). The wall dividing the warehouse space from the office space contains windows and doors, and horizontal pine boards (Figure 10).

\subsection{Exterior enclosure}

The roof is a simple gable roof at 4:12 pitch. The roof wear surface is composed of asphalt three-tab shingles. A few of the warehouses have metal roofs; those that do are noted.

Exterior walls are $9 \mathrm{ft}$ high and are framed of 2 in. $\times 6$ in. studs, 24 in. on center. There are two top plates at the top and bottom of the walls. A 2 in. $\times 6$ in. toe plate is installed at the bottom of the exterior walls.

Walls are sheathed with 6 in. board applied horizontally. The walls are insulated by foil-faced, $5^{1 / 2}$ in. fiberglass insulation that appears to have been installed after initial construction of the facility. Aluminum siding creates the exterior façade. Gutters and downspouts are also of aluminum.

The eaves and rakes of the gable ends are finished with aluminum soffit and fascia. In some cases, the top of the brick firewall that extends above the roof is covered with aluminum siding (Figure 11).

The exterior windows are each 30 in. wide by 54 in. high. The windows are mostly located near the ends of the building adjacent to the office areas. The windows are aluminum double-hung replacement-style, and some are covered with a metal grill (Figure 12). 
Figure 9. Typical warehouse wall design.

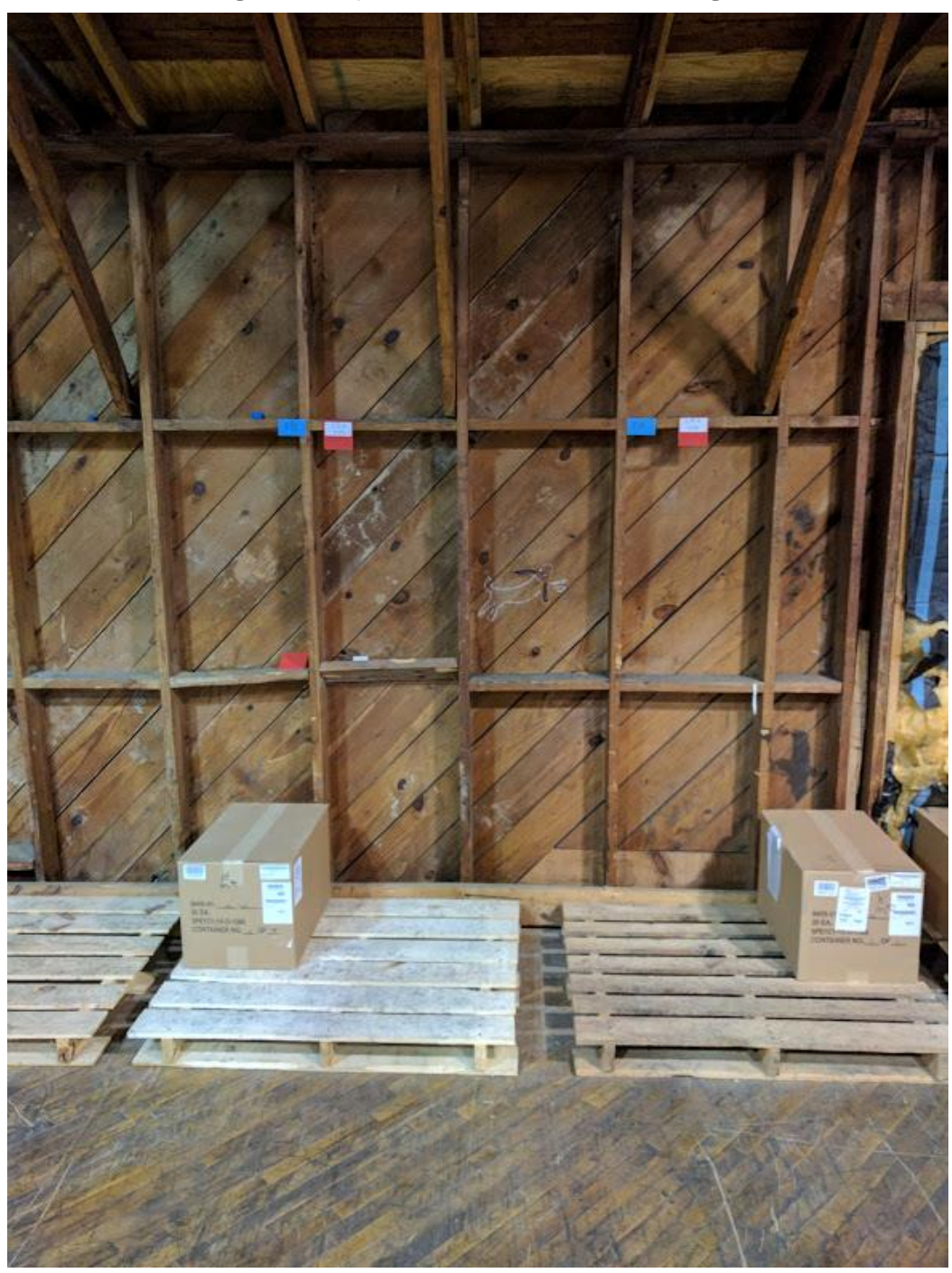

Figure 10. Wall between the warehouse and office space.

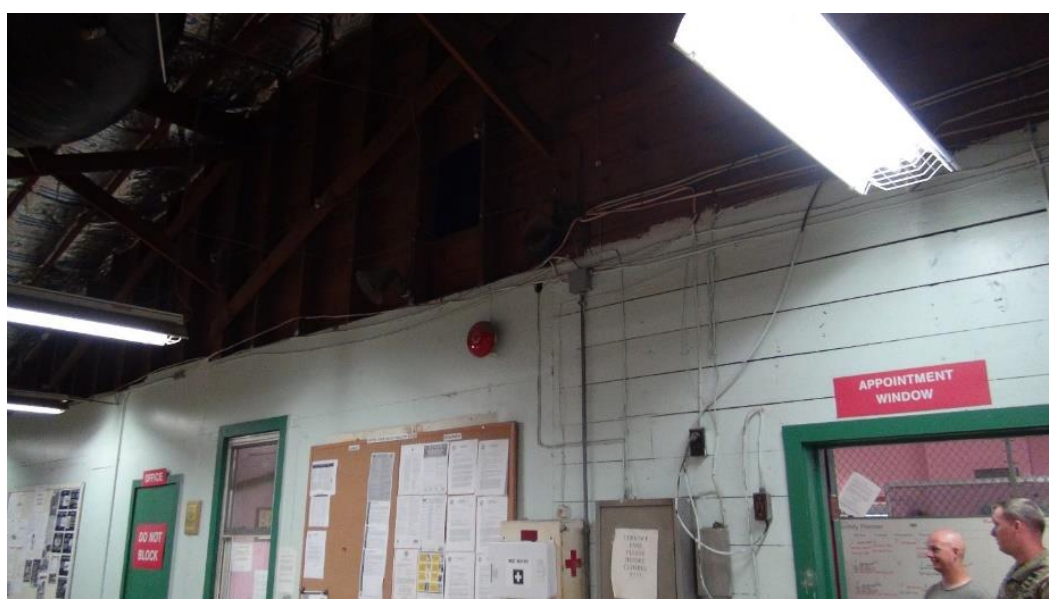


Figure 11. Brick firewall above the roof was covered with siding until damaged from weather.

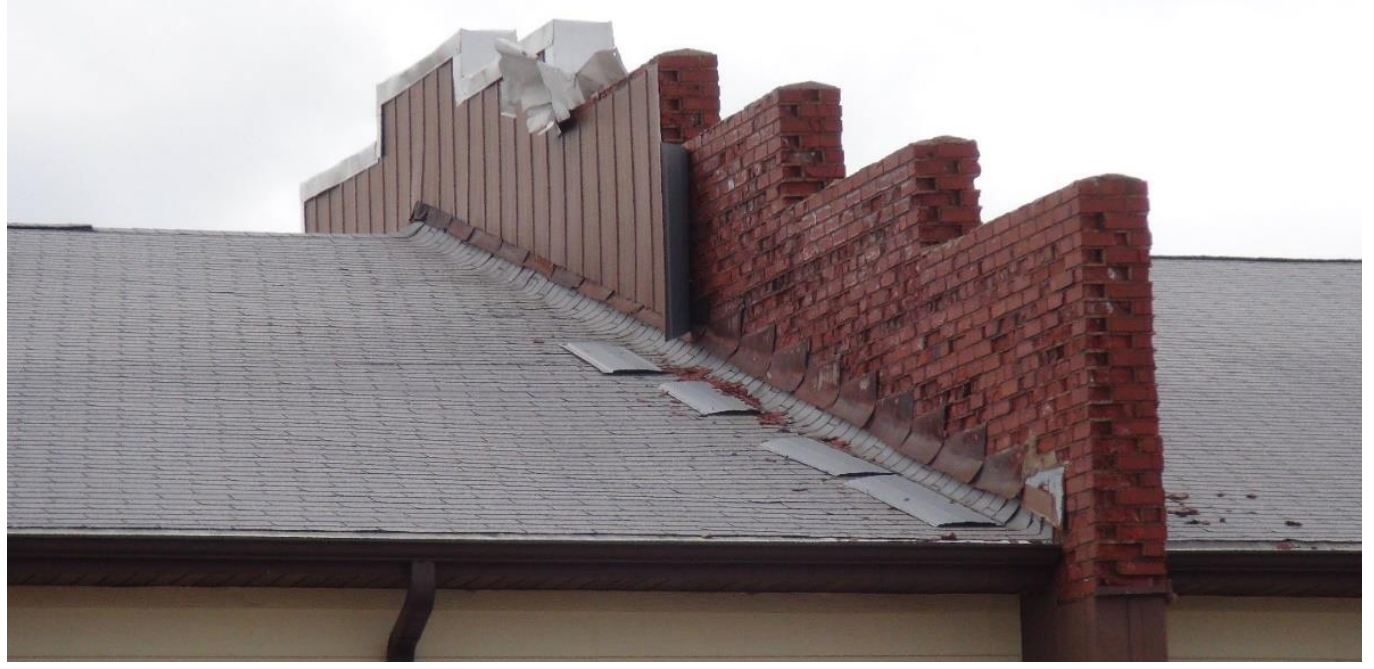

Figure 12. Typical warehouse window.

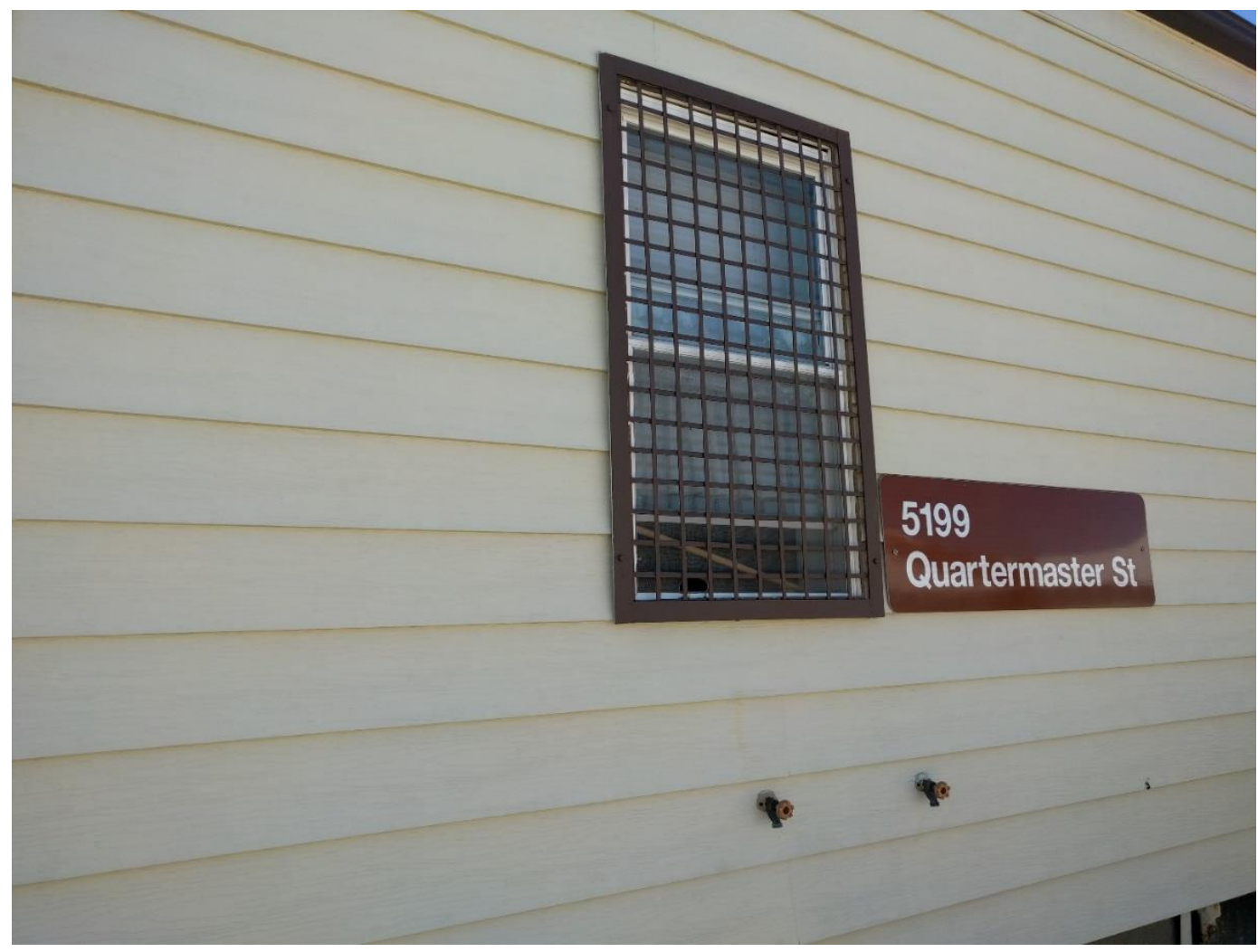

The overhead $8 \mathrm{ft} \times 8 \mathrm{ft}$ metal rollup doors are all in serviceable (reusable) condition. The 60 in. $\times 80$ in. double doors (Figure 13) and the 30 in. $\times 80$ in. single doors are also metal. 
Figure 13. Typical double door.

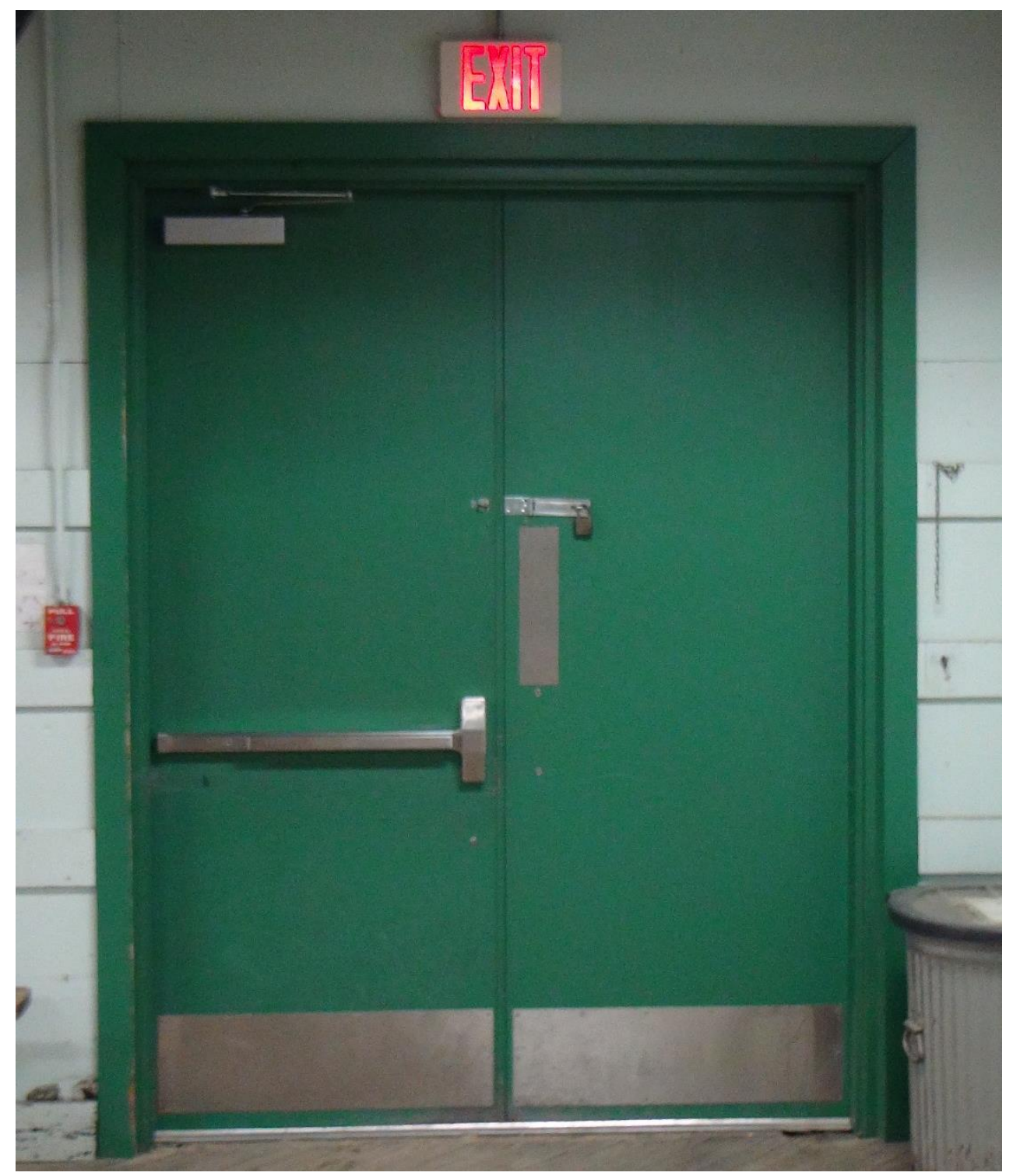

There are a number of standard size windows on each end of the building. These aluminum windows are wood framed. Along the length of the building are steel personnel doors, either single or double, and steel overhead doors for unloading trucks. The dimensions of each are:

- Windows: 30 in. $\times 54$ in.

- Single door: 30 in. $\times 80$ in.

- Double door: 60 in. $\times 80$ in.

- Overhead door: $8 \mathrm{ft} \times 8 \mathrm{ft}$ 


\subsection{Interior design}

The building's interior exemplifies typical warehouse design: wood floor, vertical support beams, and exposed framing. The entire building is insulated between the wall studs and rafters with fiberglass batt insulation. The bathrooms and office spaces have been partitioned off with pine board walls. The main warehouse areas have some panels on the walls that cover the insulation.

A thick firewall separates the two halves of the warehouse. The firewall's brick construction includes a large sliding corrugated metal door, which has potential for sale to an architectural salvage entity. Figure 14 shows the corrugated metal door separating the two adjacent warehouse buildings.

The support beams are 6 in. square beams spaced $9 \mathrm{ft}$ apart. The truss structure between the beams are $2 \times 6 \mathrm{~s}$ in the short direction and $2 \times 10 \mathrm{~s}$ in the long direction. All the lumber is dry and shows no signs of decay.

The warehouse floor is a diagonal maple flooring resting on the 2 in. $\times 12$ in. floor joists (Figure 15). The office areas in the model building are finished with insulation, wall paneling, acoustical ceiling tiles, carpeting, and extra lighting.

Figure 14. Large sliding corrugated door separating two adjacent warehouse buildings.

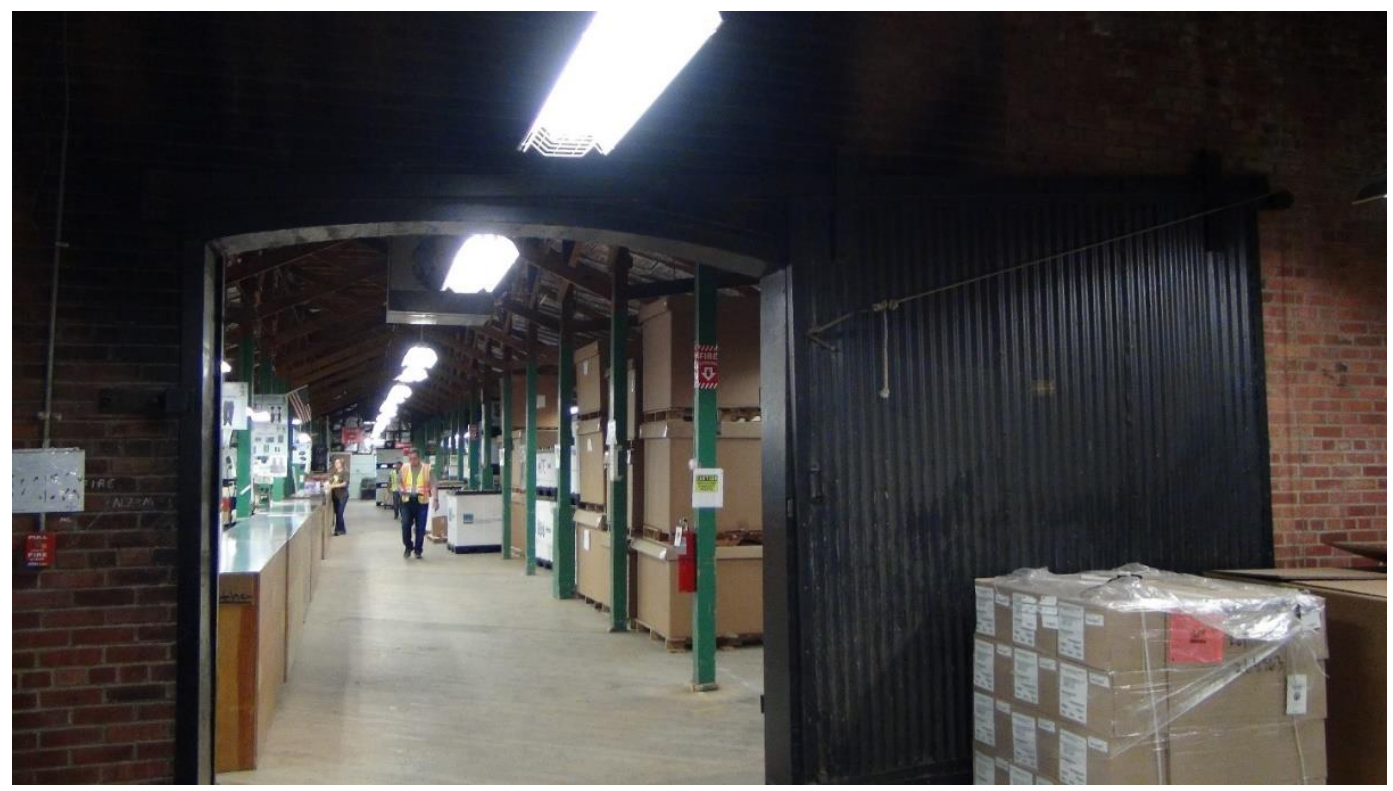


Figure 15. Typical warehouse floor, finished hardwood slats.

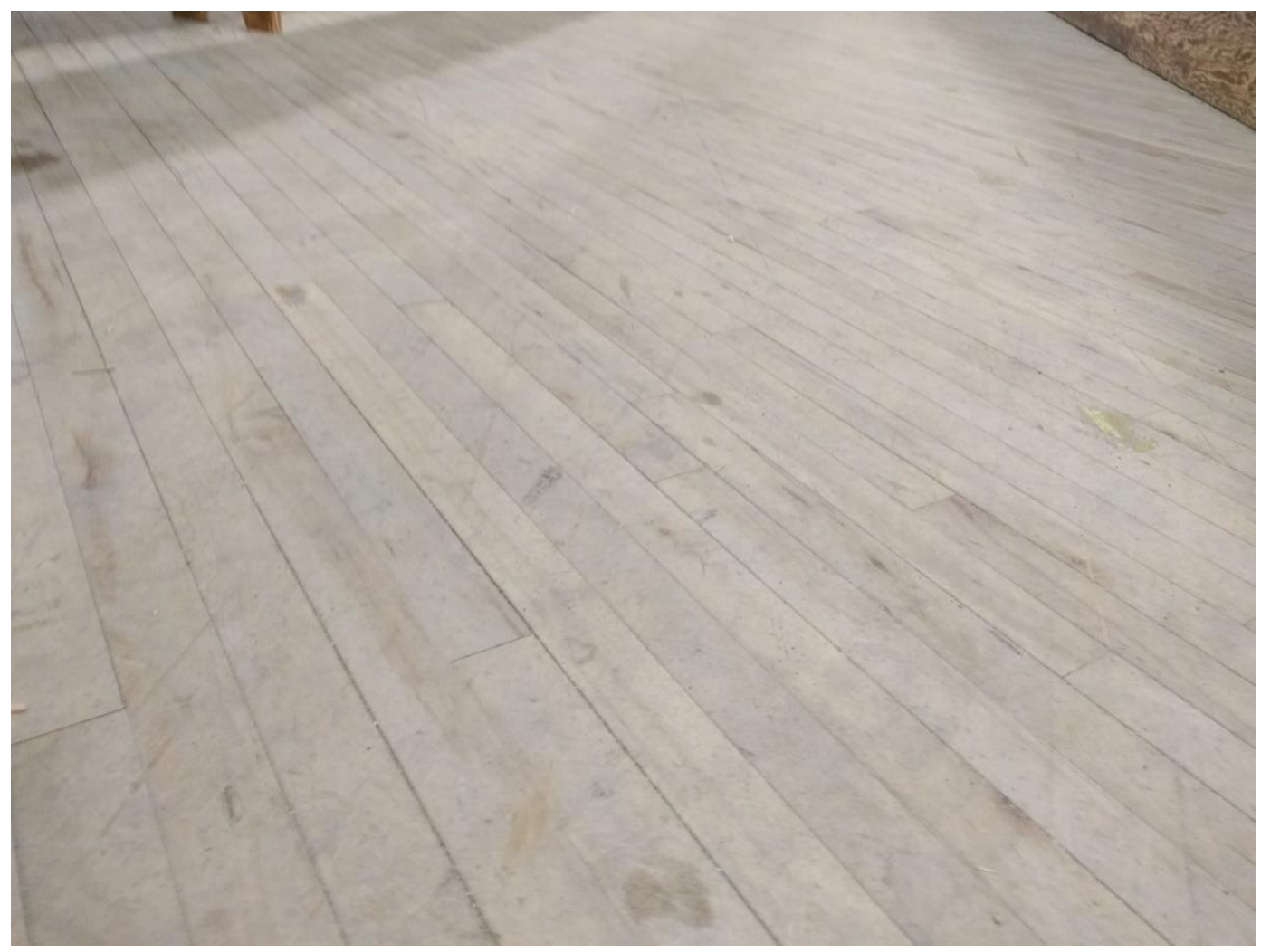

\subsection{Plumbing}

The model Bldgs. 2338 and 2339 contain one bathroom each with the following ceramic fixtures: two toilets, one urinal, and one sink (Figure 16). The units were originally plumbed with cast iron pipe, but sections have been replaced with PVC. There is also a small amount of brass piping/valves for each fixture.

There is one drinking water fountain in each warehouse building (Figure 17). It is an upright unit with self-contained refrigeration.

\subsection{Mechanical}

The bathrooms each contain a modern furnace unit (Figure 18) with sheet metal ducting to the adjacent office spaces. The units are small and in good condition. Outside the building, six A/C units are connected to the building by large diameter flexible ducting (Figures 19 and 20). There is one ceilingmounted fan coil unit in each main warehouse area (Figure 21). 
Figure 16. Typical warehouse restroom facility: toilet, urinal, and sink.

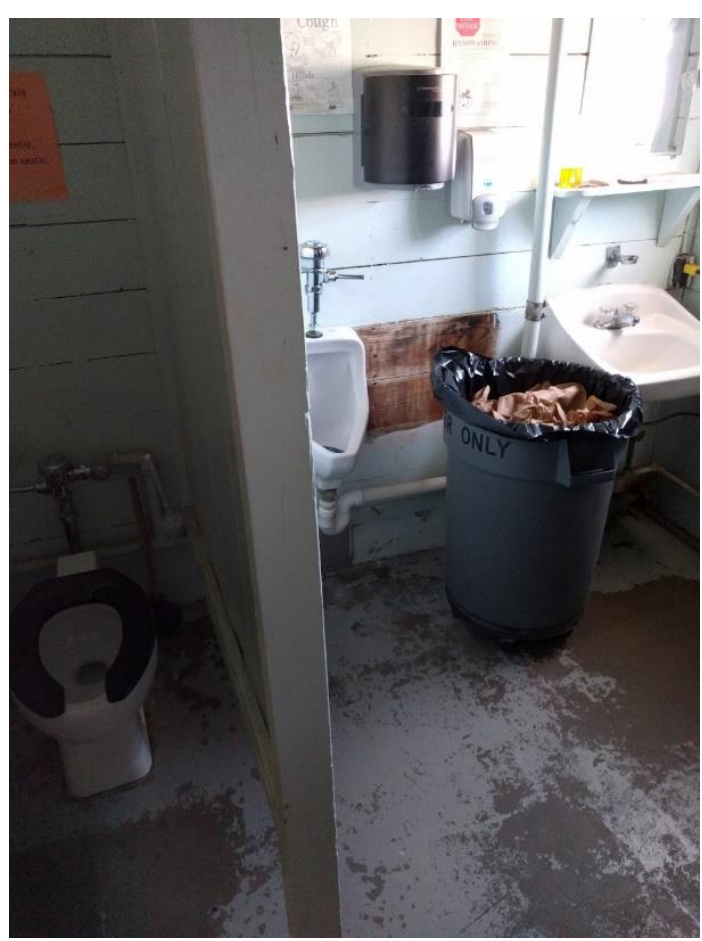

Figure 17. Typical drinking fountain.

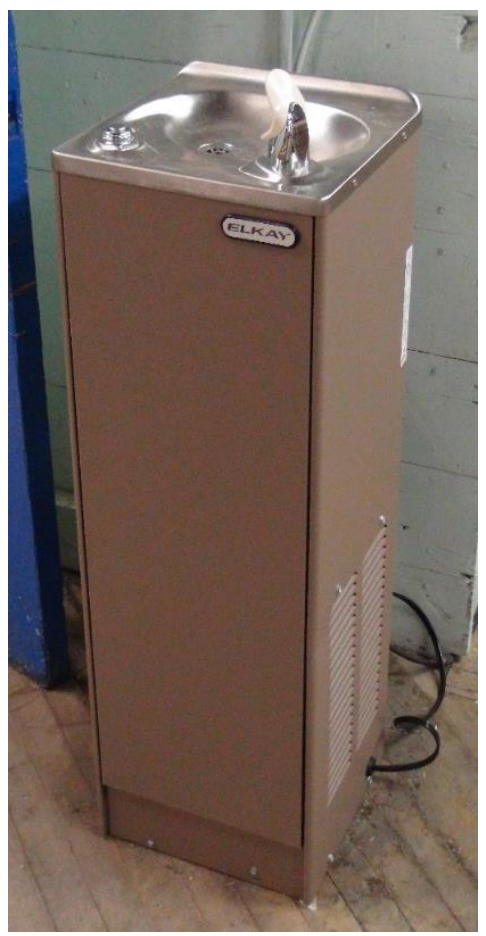

Figure 18. Typical furnace for office spaces and restroom facilities.

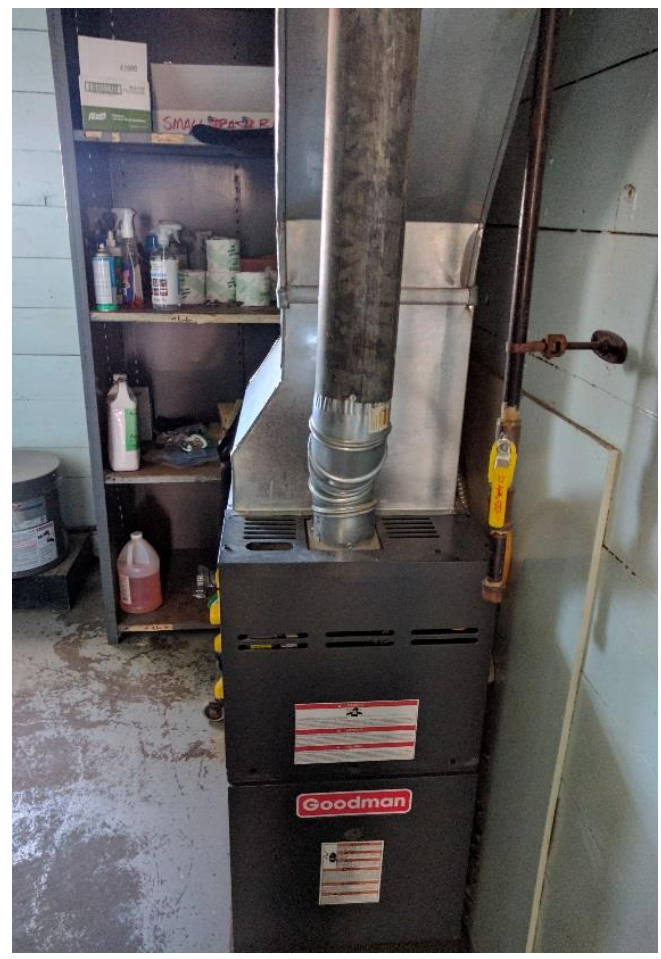

Figure 19. A/C units outside of warehouses.

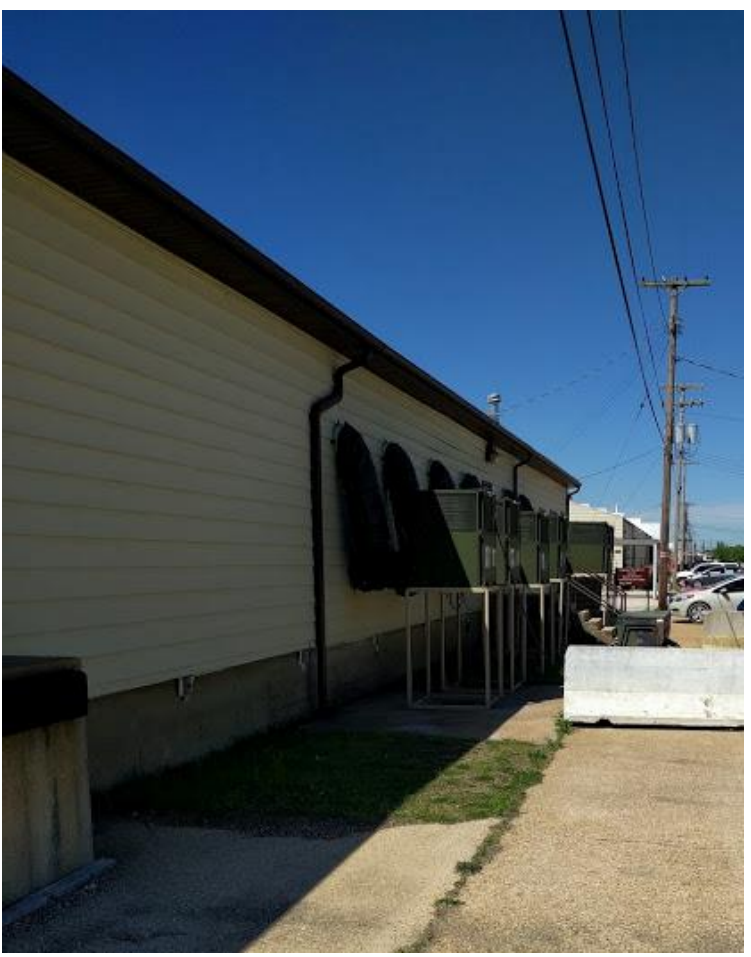


Figure 20. Close-up of exterior $\mathrm{A} / \mathrm{C}$ units outside of model building.

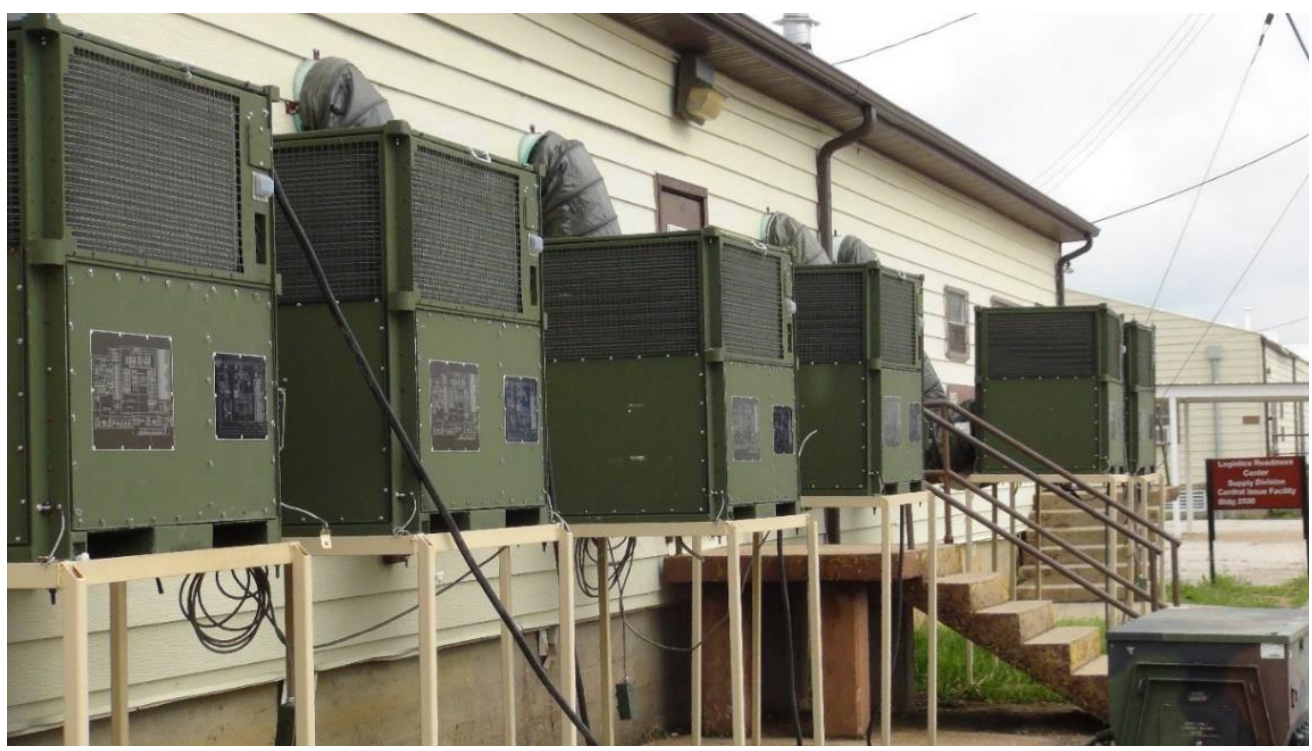

Figure 21. Ceiling-mounted fan coil unit in main warehouse area.

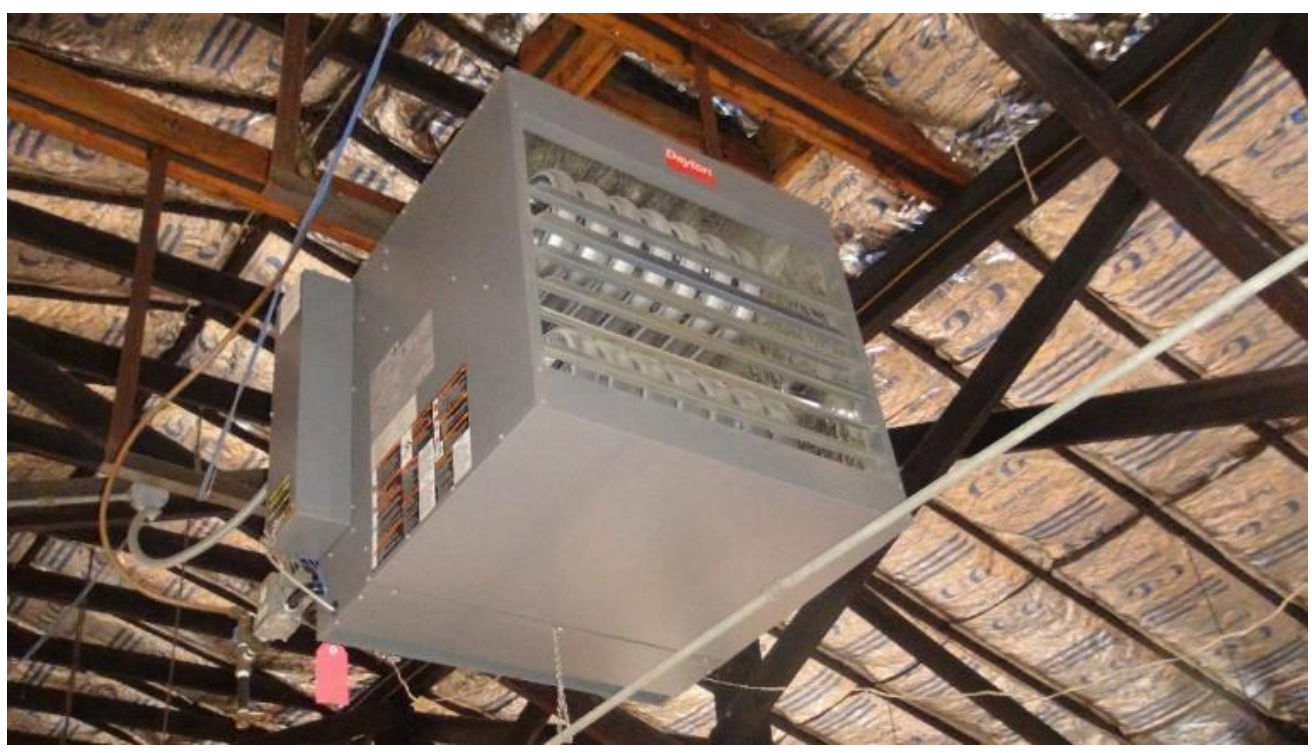

\subsection{Electrical}

Each main warehouse area is illuminated by five rows of fluorescent lights that run the length of the building. Each row has 17, $4 \mathrm{ft}$, two-tube industrial ceiling-hung fluorescent light fixtures (Figure 22). No electrical conduit was observed except between the light fixtures themselves. Electrical panels were present. 
Figure 22. Typical fluorescent lighting in warehouse area.

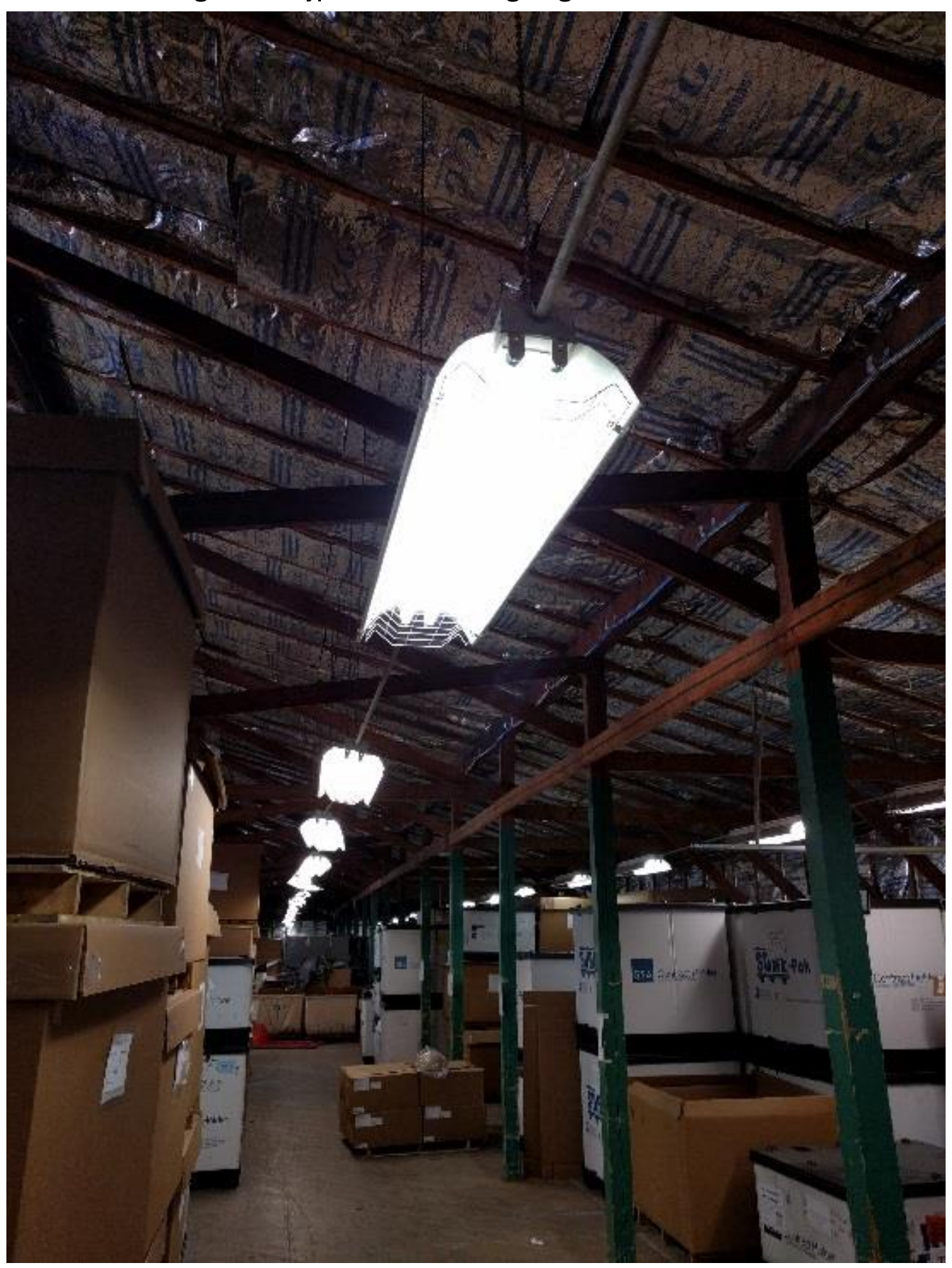




\section{Remaining Buildings}

As noted, most buildings in the warehouse district have a common floor plan, size, and construction. The following sections depict the major differences between each of the warehouses included in this investigation and the model.

\subsection{Bldg. 2303}

Bldg. 2303 (Figure 23) is constructed differently from the model building. It has a single bay, $63 \mathrm{ft}$ long and $25 \mathrm{ft}$ wide. It has a single $12 \mathrm{ft} \times 12 \mathrm{ft}$ garage door and eight windows. No plumbing or electrical fixtures were observed. The concrete footings were 8 in. thick. The total volume method was used to determine the cost of demolition and deconstruction, since the interior was not readily accessible, and a breakdown of materials was not generated. The total volume of the building is approximately $30,700 \mathrm{ft} 3$. Adjacent to the building is a fenced-off restricted area containing fuel tanks and other military items.

Figure 23. Bldg. 2303.

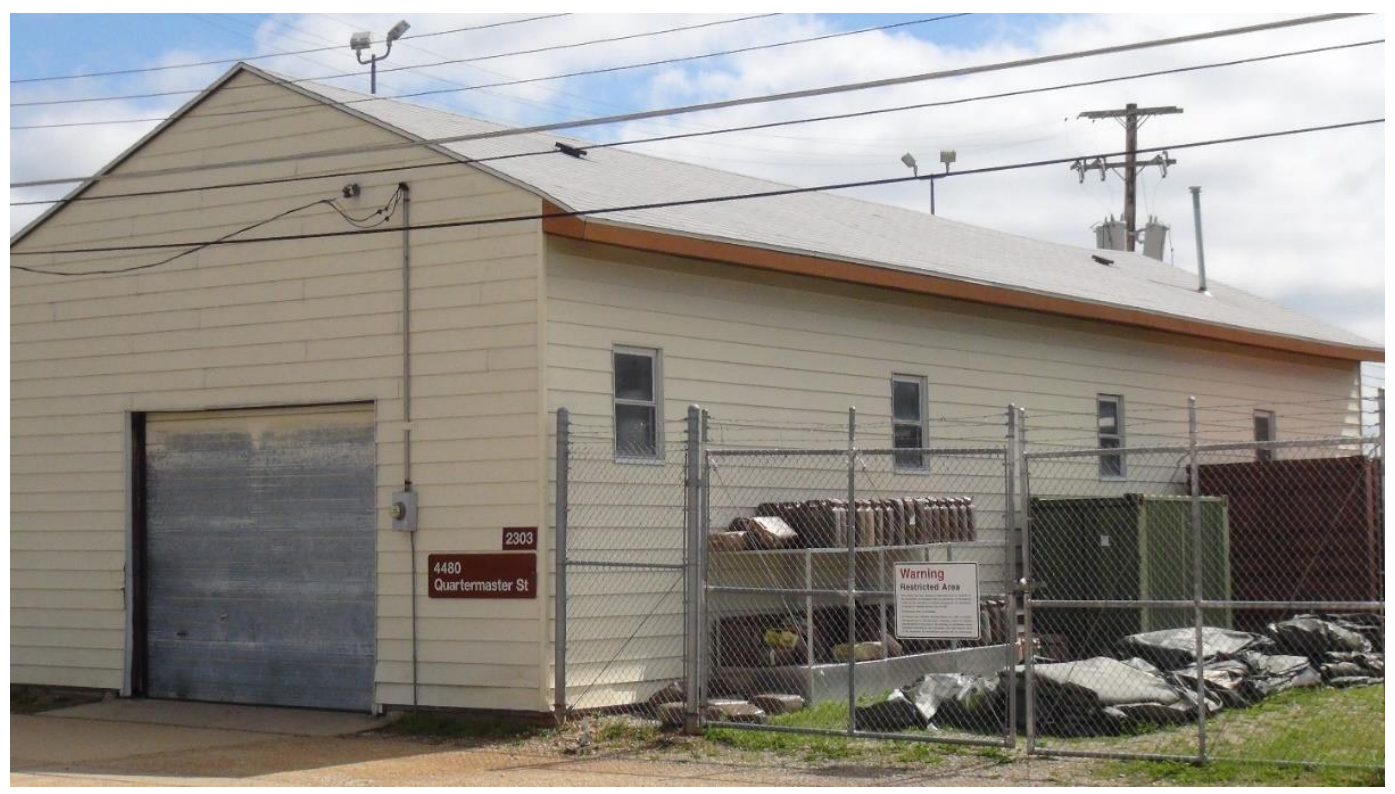

\subsection{Bldg. 2307}

Bldg. 2307 (Figures 24 and 25) has the same dimensions and design as Bldg. 2303. Each building has one garage door, one personnel door, and eight windows. 
Figure 24. Bldg. 2307.

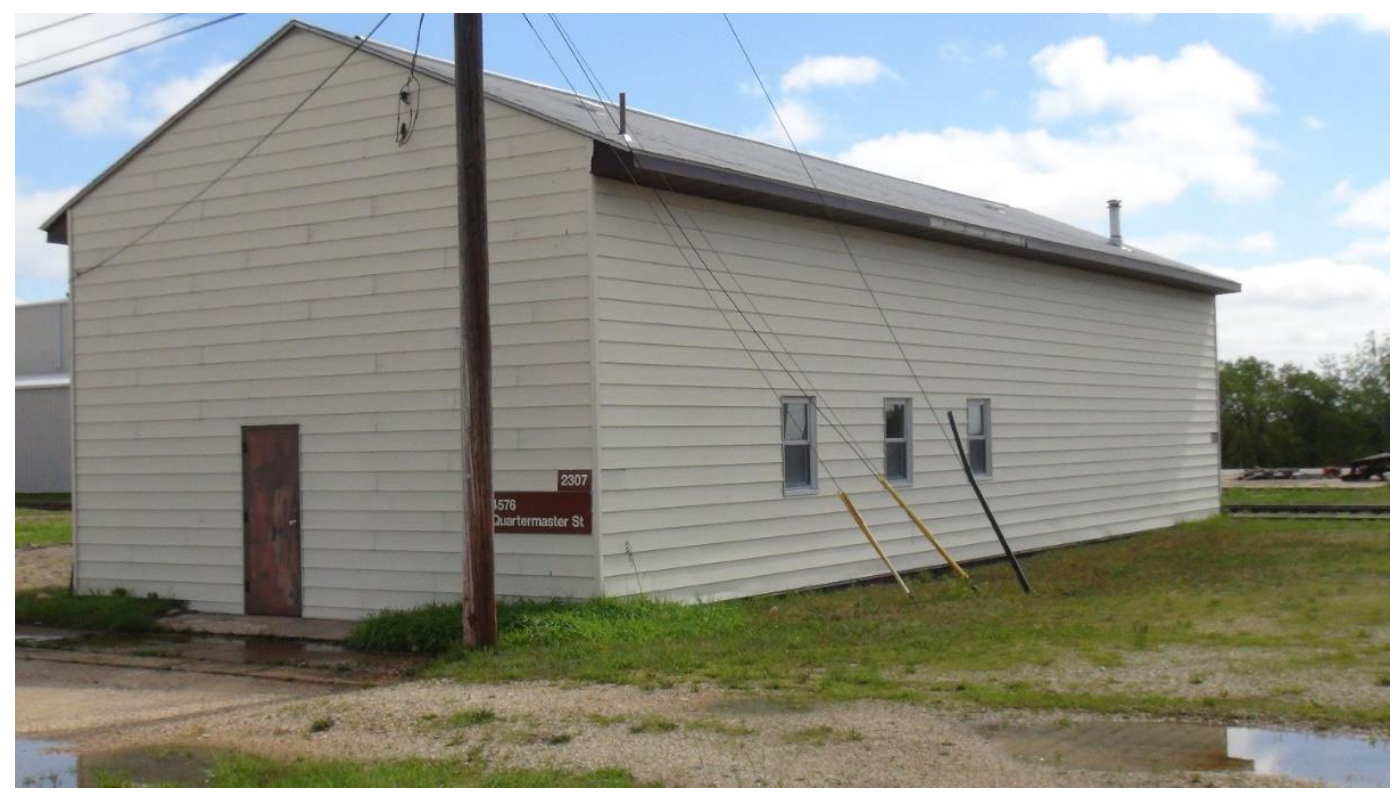

Figure 25. Bldg. 2307, garage door side.

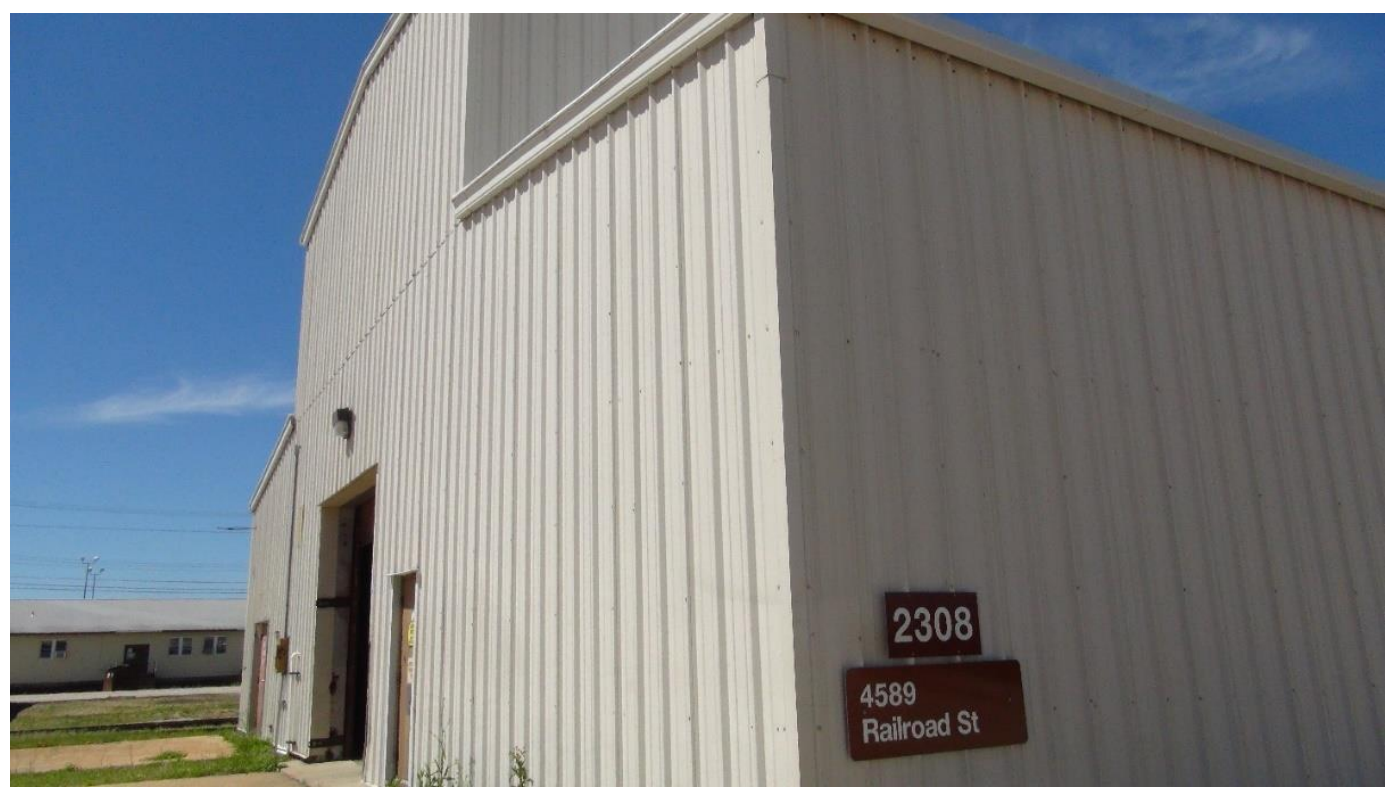

\subsection{Bldg. 2308}

Bldg. 2308 is unlike any other building in the warehouse district. It has a metal beam and column construction and is significantly larger than the others. The roof is metal, there are large glass windows, brick walls, steel caging, concrete floor, finished office space, an overhead crane, and bathrooms with shower facilities (Figures 26 and 27). 
Figure 26. Bldg. 2308, lengthwise view.

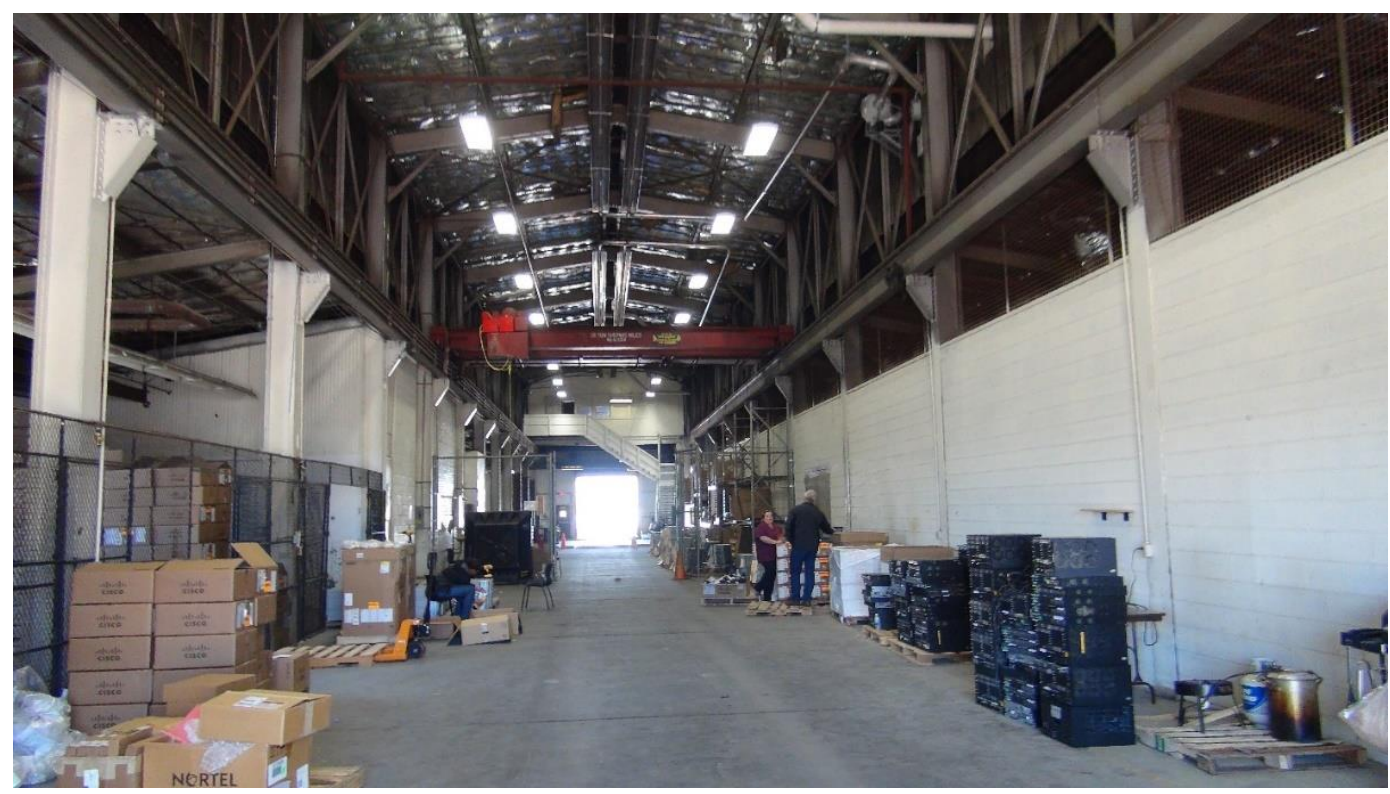

Figure 27. Bldg. 2308, view of wall and ceiling.

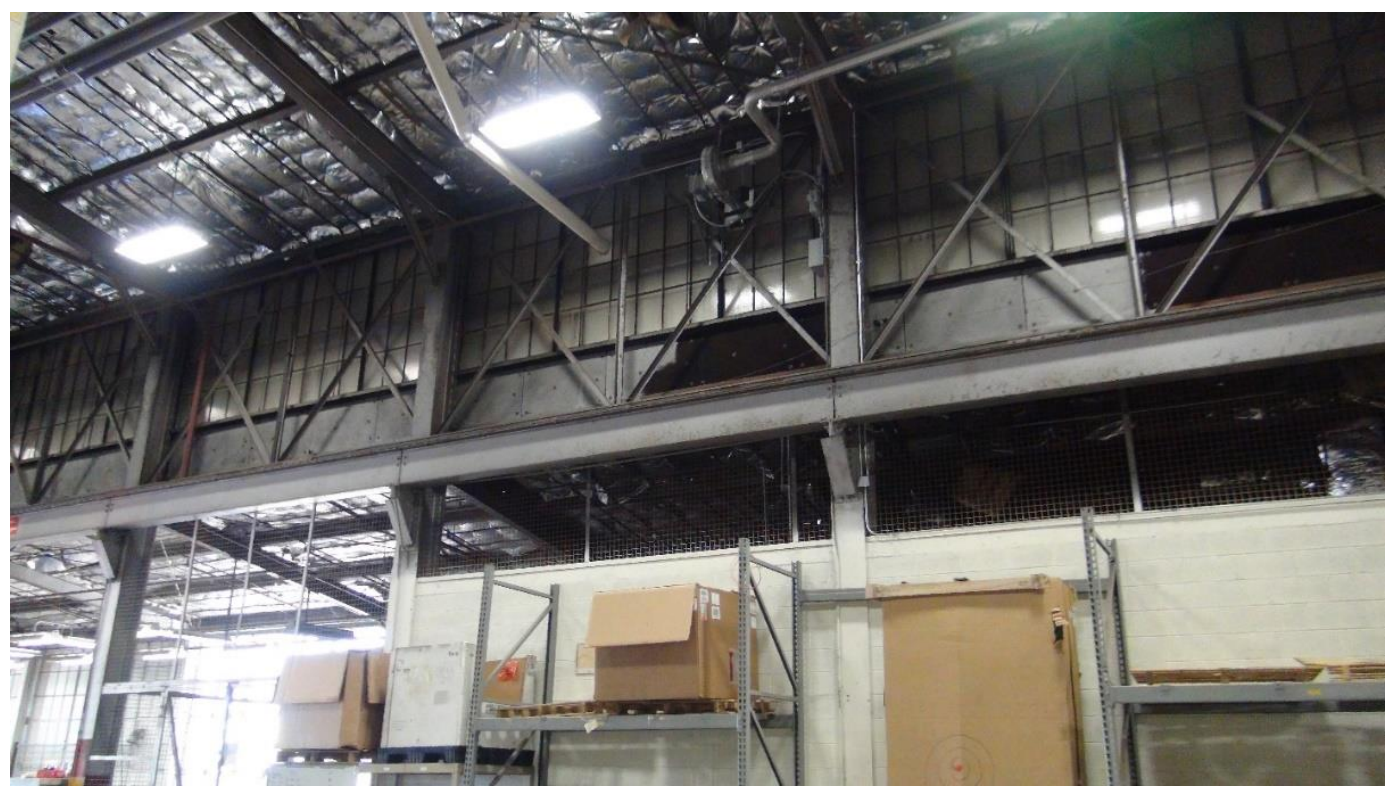

\subsection{Bldgs. 2310-2311}

The main differences that distinguish Bldgs. 2310-2311 from the model include are as follows: the number of windows, doors, A/C units, and lights; the interior ductwork; and the inclusion of a brick chimney and a fire sprinkler system. The Kansas City District conducted a detailed assessment of these buildings; 8.2Appendix A includes their findings. 


\subsection{Bldgs. 2313-2314}

The main differences that distinguish Bldgs. 2313-2314 from the model are the number of windows, doors, A/C units, and lights.

\subsection{Bldg. 2315}

The main differences that distinguish Bldg. 2315 (Figure 28) from the model are the number of windows, doors, and A/C units. Also, this building is no longer adjacent to another building, and a shed has been constructed to the north. On the inside, the north end has been converted into office space, and the south end is of typical warehouse design but contains no insulation.

Figure 28. Bldg. 2315.

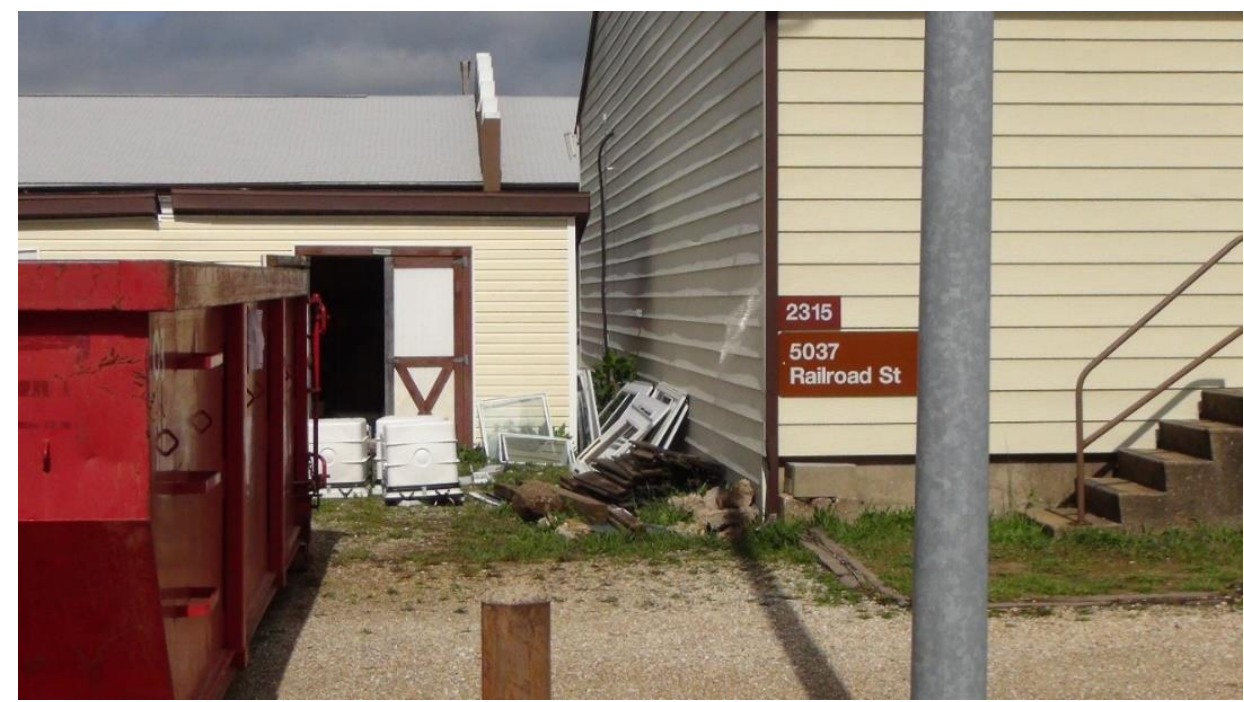

\subsection{Bldg. 2318}

The main differences that distinguish Bldg. 2318 from the model are the number of windows, doors, and A/C units. Like Bldg. 2315, this building is no longer adjacent to another building. On the inside, the north end contains no insulation. The floor is plywood. Also, Bldg. 2318 has a metal roof instead of asphalt.

\subsection{Bldgs. 2319-2320}

The main differences that distinguish Bldgs. 2319-2320 from the model are the number of windows, doors, and lights. Also, both buildings did not contain insulation, but both did contain a fire sprinkler system that includes five runs of pipe that span the length of the building. 


\subsection{Bldgs. 2321-2322}

The main differences between Bldgs. 2321-2322 and the model are the number of windows, doors, and A/C units. There was A/C ductwork inside the building. In Bldg. 2321, the walls were covered with gypsum board up to a height of $9 \mathrm{ft}$. In Bldg. 2322, the ceiling was covered with gypsum board and a fire sprinkler system that includes four runs of pipe that span the length of the building. Propane boilers were also present.

\subsection{Bldgs. 2323-2324}

The main differences that distinguish Bldgs. 23232324 from the model are the number of windows, doors, and $\mathrm{A} / \mathrm{C}$ units.

\subsection{Bldgs. 2325-2326}

The main differences that distinguish Bldgs. 2325-2326 (Figure 29) from the model are the number of windows, doors, and $\mathrm{A} / \mathrm{C}$ units. On the inside, the south end has been converted into an office space, while the north remains a warehouse. The walls and ceiling are covered with gypsum board. There are fewer lights than in the model and Bldg. 2326 has no insulation.

Figure 29. Bldgs. 2325-2326.

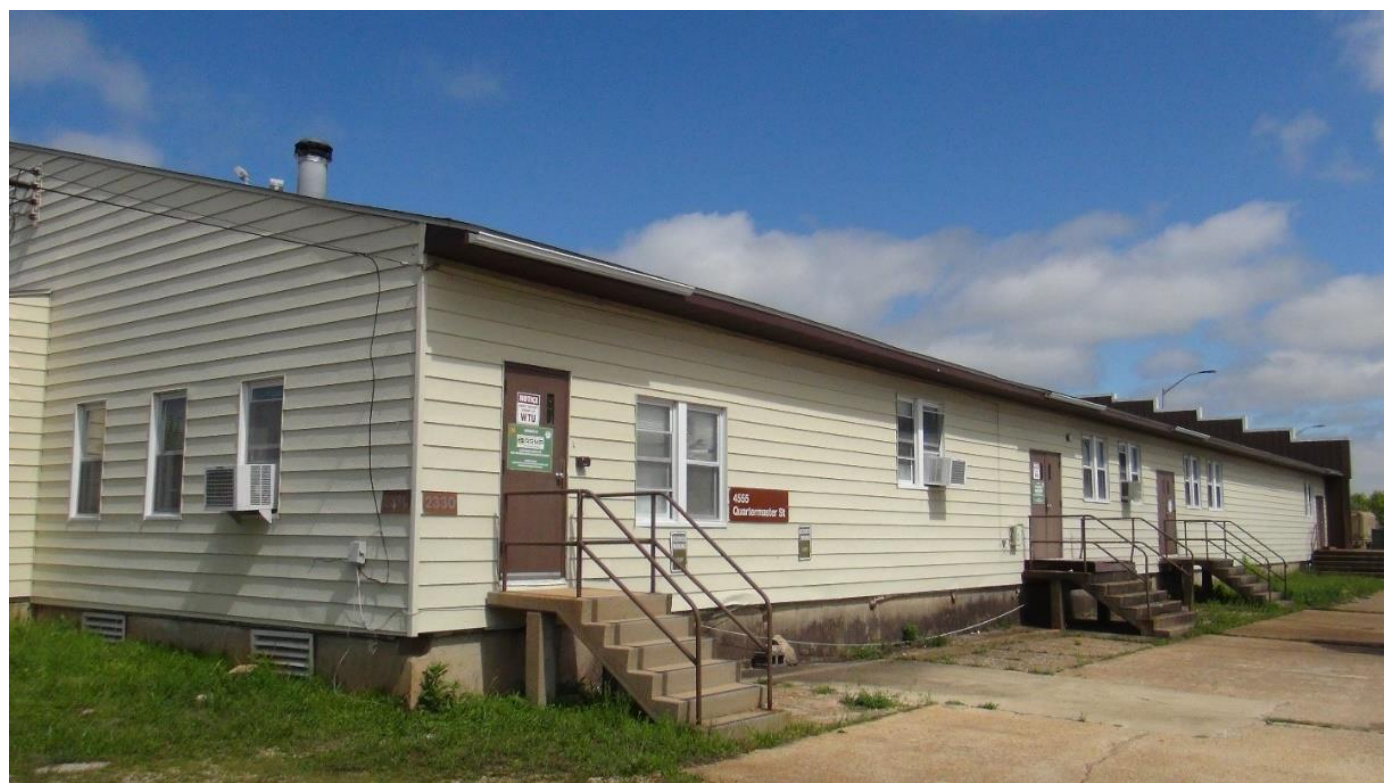




\subsection{Bldgs. 2330}

The main differences that distinguish Bldg. 2330 (Figure 30) from the model are the number of windows, doors, A/C units, and lights. Like Bldg. 2315, this building is not adjacent to another building, but the size and layout remains the same. Also, Bldg. 2318 has a boiler. The Kansas City District conducted a detailed assessment of this building; Section 8.2B.1 includes their findings.

Figure 30. Bldg. 2330.

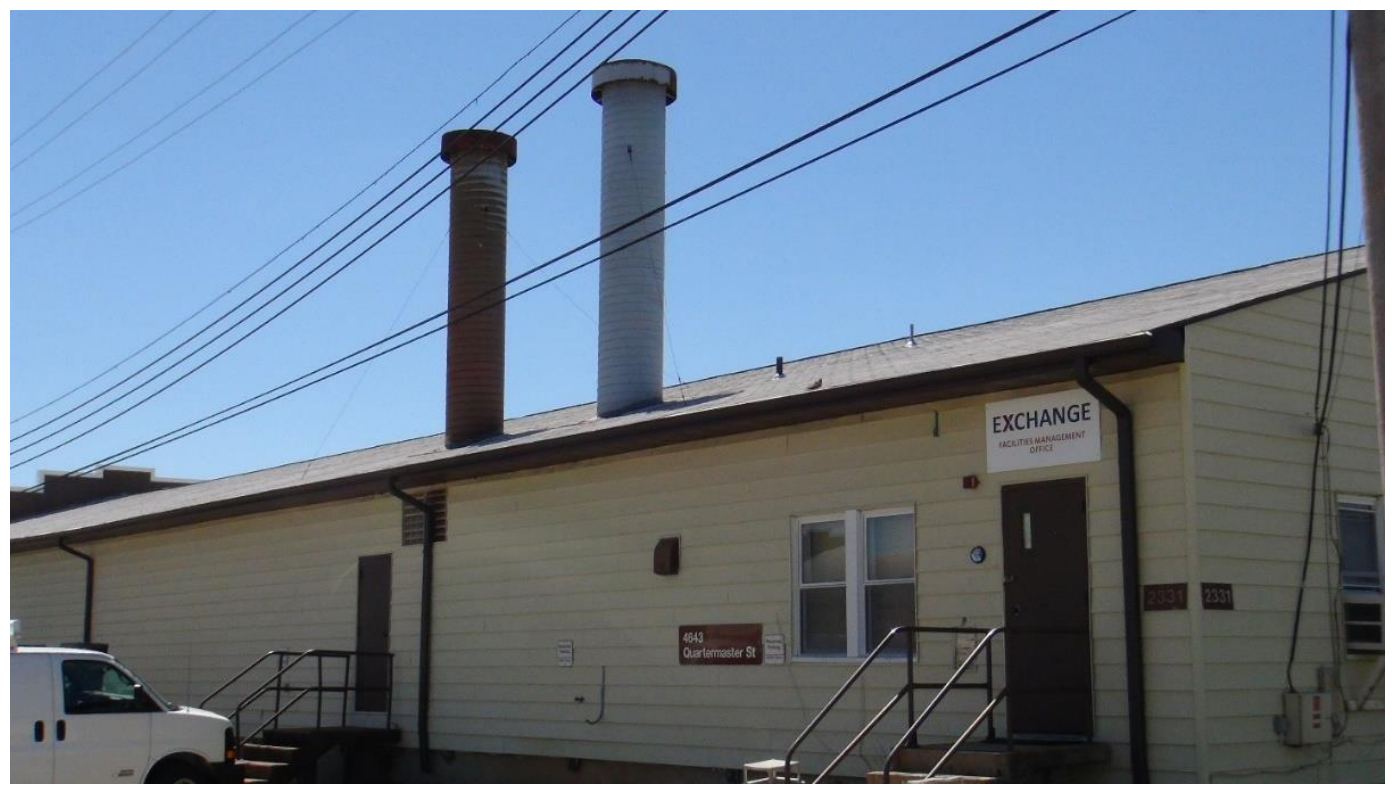

\subsection{Bldgs. 2331-2332}

The main differences that distinguish Bldgs. 2331-2332 from the model are the number of windows, doors, A/C units, and amount of ductwork. Bldg. 2331 has no insulation, and its floor is plywood. The Kansas City District conducted a detailed assessment of Bldg. 2332; 8.2Appendix B includes their findings.

\subsection{Bldgs. 2334-2335}

The main differences that distinguish Bldgs. 2334-2335 from the model are the number of windows, doors, and $\mathrm{A} / \mathrm{C}$ units. In addition, this building has a metal roof instead of asphalt. 


\subsection{Bldgs. 2336-2337}

The main differences that distinguish Bldgs. 2336-2337 from the model are the number of windows, doors, and A/C units. In addition, this building has a metal roof instead of asphalt.

\subsection{Bldgs. 2340-2341}

The main differences that distinguish Bldgs. 2340-2341 from the model are the number of windows, doors, and $\mathrm{A} / \mathrm{C}$ units.

\subsection{Bldgs. 2340-2341}

The main differences that distinguish Bldgs. 2340-2341 from the model are the number of windows, doors, and $\mathrm{A} / \mathrm{C}$ units.

\subsection{Bldgs. 2342-2343}

The main differences that distinguish Bldgs. 2342-2343 (Figure 31) from the model are the number of windows, doors, and $\mathrm{A} / \mathrm{C}$ units. The inside of the building contains old ductwork, an acoustic tile ceiling, and gypsum board partitions. The walls are covered to $9 \mathrm{ft}$ height with $1 / 2 \mathrm{in}$. wallboard siding. The floor is of plywood.

Figure 31. Bldg. 2343.

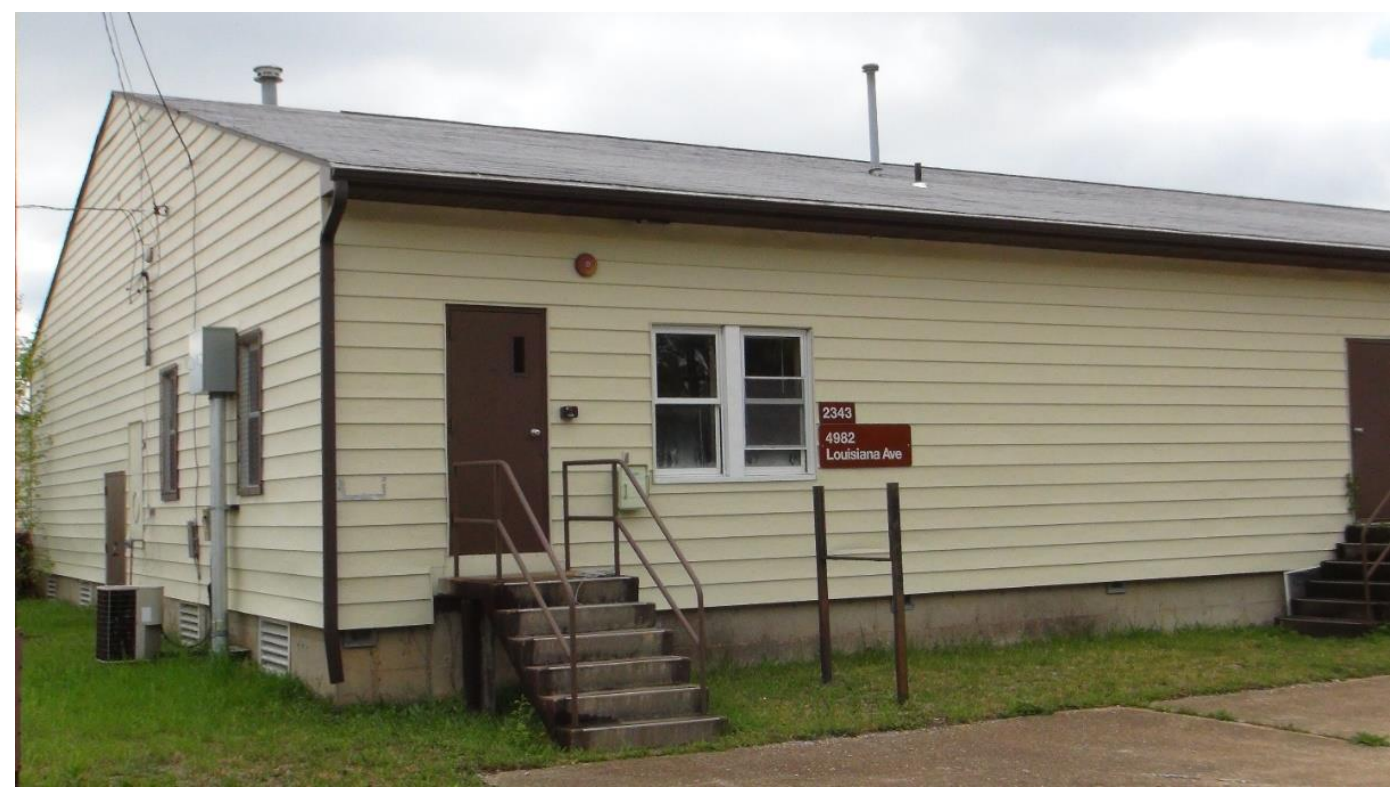




\subsection{Bldgs. 2344-2345}

The main differences that distinguish Bldgs. 2342-2343 (Figures 32 and 33 ) from the model are the number of windows, doors, and A/C units. In addition, there is an interior chain link cage, additional office space, a double basin sink, additional ductwork, and fewer lights. The Kansas City District conducted a detailed assessment of these buildings; Appendix D includes their findings.

Figure 32. Bldg. 2344.

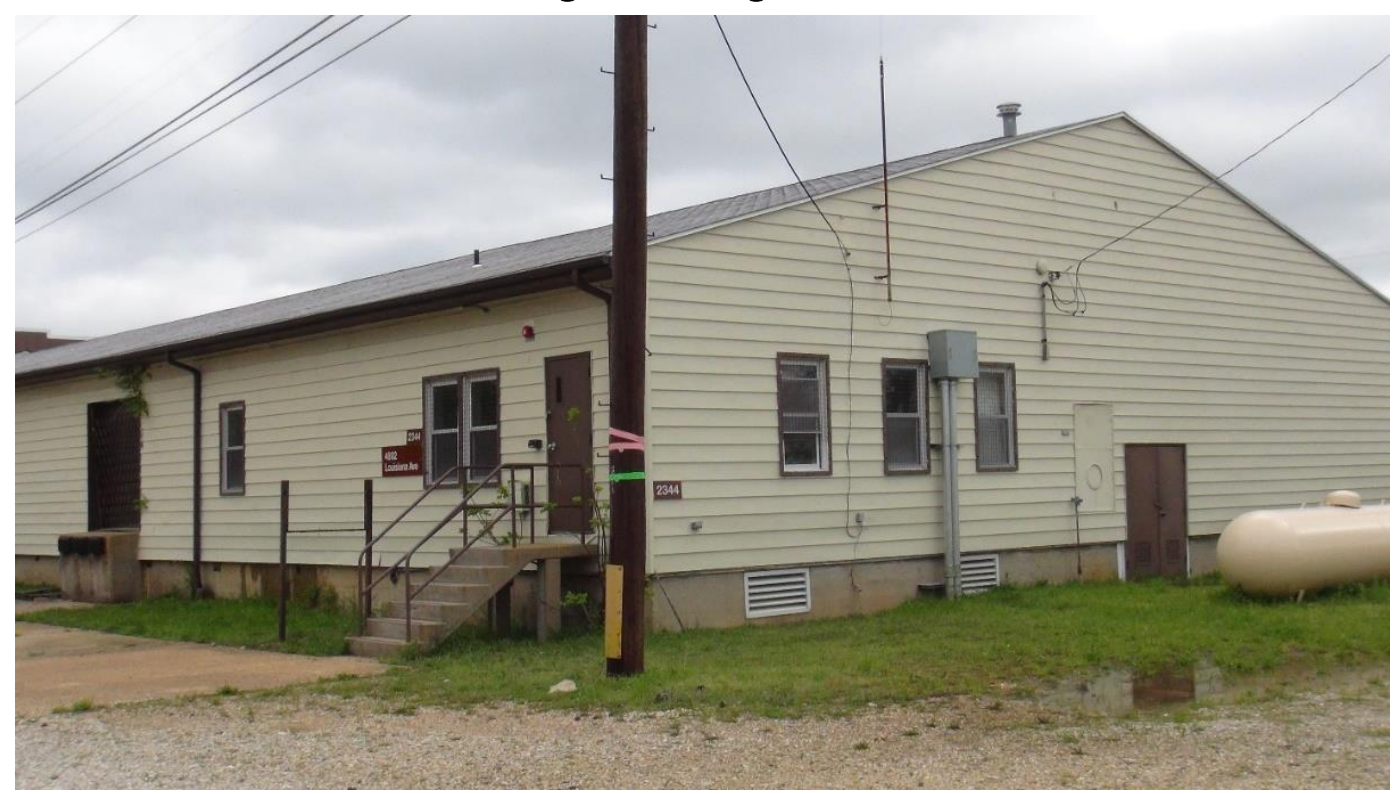

Figure 33. Bldg. 2345.

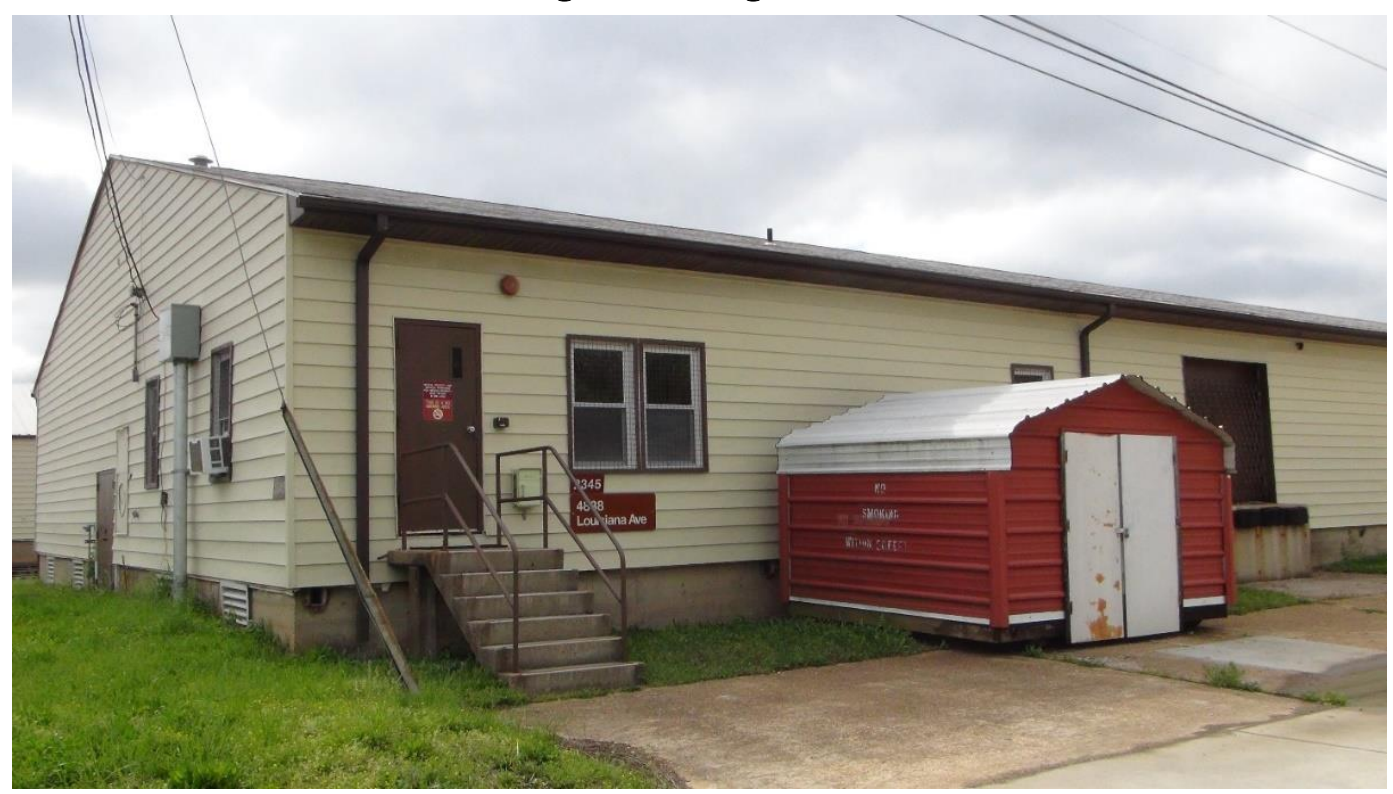




\section{Building Materials Assessment}

As mentioned, the warehouses are constructed of wood on concrete footings. The warehouses are composed of a number of specific materials (wood, concrete, metal, asphalt shingles, fiberglass insulation, and bricks) that are easily quantified by rough estimate.

To determine the amount of each material, the dimensions of the building were measured, and the quantity of materials contained in various components was estimated. The different components include the following: 2 in. $\times 4$ in. roof, 2 in. $\times 4$ in. wall, wall panel, 2 in. $\times 6$ in. truss, 6 in. $\times 6$ in. beam, wall insulation, ceiling insulation, chicken wire, maple flooring, floor joist, roof sheathing, roofing, bricks, and concrete footings. Table 1 lists the estimated quantities for the model buildings.

On the interior, the electrical, plumbing, and HVAC elements were counted to determine the number of fixtures in all the buildings. Table 2 lists the number of toilets, sinks, water fountains, furnaces, fan coil units, and boilers.

Table 1. Estimated material quantities for the model Bldgs. 2338 and 2339.

\begin{tabular}{|l|r|r|r|r|}
\hline Material Quantities & Length $(\mathrm{ft})$ & Area $\left(\mathrm{ft}^{2}\right)$ & Volume $\left(\mathrm{ft}^{3}\right)$ & Board Feet \\
\hline Roof 2 in. $\times 4$ in. & 9,612 & & 350 & 4,205 \\
\hline Wall 2 in. $\times 4$ in. & 2,736 & & 100 & 1,197 \\
\hline Wall panel & & 4,712 & & \\
\hline Truss 2 in. $\times 6$ in. & 4,640 & & 266 & 3,190 \\
\hline 6 in. $\times 6$ in. beams & 1,920 & & 403 & 4,840 \\
\hline Wall insulation & & 7,114 & & \\
\hline Ceiling insulation & & 19,187 & & \\
\hline Chicken wire & & 19,225 & & \\
\hline Maple flooring & & 18,240 & & 13,680 \\
\hline Floor joist & 18,240 & & 2,280 & 27,360 \\
\hline Roof sheathing & & & & \\
\hline Roofing & & 19,225 & & \\
\hline Bricks & & 1,920 & & \\
\hline
\end{tabular}


Table 2. Summary of indoor fixtures.

\begin{tabular}{|c|c|c|c|c|c|c|c|c|c|}
\hline Building & Toilets & Urinals & Sinks & $\begin{array}{c}\text { Water } \\
\text { Fountains }\end{array}$ & Showers & Boiler & $\begin{array}{l}\text { Fan Coil } \\
\text { Units }\end{array}$ & Furnaces & $\begin{array}{l}\text { Light } \\
\text { Fixtures }\end{array}$ \\
\hline 2303 & 0 & 0 & 0 & 0 & 0 & & & & \\
\hline 2307 & 0 & 0 & 0 & 0 & 0 & & & & \\
\hline 2308 & 4 & 2 & 4 & 1 & 2 & 2 & 0 & 0 & 26 \\
\hline $2310-2311$ & 1 & 0 & 1 & 0 & 0 & 0 & 0 & 2 & 140 \\
\hline \multicolumn{10}{|l|}{$2313-2314$} \\
\hline \multicolumn{10}{|l|}{2315} \\
\hline \multicolumn{10}{|l|}{2318} \\
\hline \multicolumn{10}{|l|}{$2319-2320$} \\
\hline \multicolumn{10}{|l|}{ 2321-2322 } \\
\hline \multicolumn{10}{|l|}{$2323-2324$} \\
\hline \multicolumn{10}{|l|}{$2325-2326$} \\
\hline 2330 & 1 & 0 & 1 & 0 & 0 & 1 & 7 & 0 & 95 \\
\hline $2331-2332$ & - & - & - & 0 & 0 & 0 & 0 & 2 & 50 \\
\hline \multicolumn{10}{|l|}{$2334-2335$} \\
\hline \multicolumn{10}{|l|}{$2336-2337$} \\
\hline $2338-2339$ & 4 & 2 & 2 & 2 & 0 & 1 & 4 & 2 & 170 \\
\hline \multicolumn{10}{|l|}{$2340-2341$} \\
\hline \multicolumn{10}{|l|}{$2342-2343$} \\
\hline $2344-2345$ & 5 & 3 & 3 & 2 & 0 & 1 & 0 & 2 & 45 \\
\hline
\end{tabular}

The exterior building components were carefully counted by walking the perimeter of each warehouse. Table 3 lists the number of windows, doors, and $\mathrm{A} / \mathrm{C}$ units at all warehouses.

\subsection{Method}

After the various material quantities and building elements were established, the $R S$ Means Handbook was used to identify costs for demolition, deconstruction, and salvage for each material category. Demolition is defined as a method that incurs no effort to save or preserve any building components. This is the cheapest method of removing a structure. All components are destroyed and taken to a landfill. Deconstruction, on the other hand, involves the careful dismantling of the structure to preserve or reuse various components. This method is inherently more time consuming and thus expensive. However, the items of value can be salvaged by recycling or reuse. 
Table 3. Summary of exterior building elements for all warehouses.

\begin{tabular}{|c|c|c|c|c|c|c|}
\hline Building & Windows & $\begin{array}{c}\text { Single } \\
\text { Doors }\end{array}$ & $\begin{array}{c}\text { Double } \\
\text { Doors }\end{array}$ & $\begin{array}{c}\text { Overhead } \\
\text { Doors }\end{array}$ & $\begin{array}{c}\text { Window } \\
\text { AC }\end{array}$ & $\begin{array}{c}\text { Ground } \\
\text { AC }\end{array}$ \\
\hline 2303 & 8 & 0 & 0 & 1 & 0 & 0 \\
\hline 2307 & 8 & 1 & 0 & 1 & 0 & 0 \\
\hline 2308 & 2 & 2 & 2 & 0 & 0 & 0 \\
\hline $2310-2311$ & 7 & 6 & 1 & 2 & 0 & 0 \\
\hline $2313-2314$ & 11 & 5 & 0 & 6 & 1 & 1 \\
\hline 2315 & 6 & 4 & 1 & 2 & 0 & 0 \\
\hline 2318 & 6 & 2 & 0 & 4 & 0 & 1 \\
\hline $2319-2320$ & 15 & 3 & 1 & 4 & 0 & 0 \\
\hline $2321-2322$ & 32 & 7 & 1 & 3 & 6 & 0 \\
\hline $2323-2324$ & 15 & 5 & 1 & 4 & 0 & 2 \\
\hline $2325-2326$ & 9 & 2 & 0 & 7 & 1 & 2 \\
\hline 2330 & 10 & 1 & 4 & 0 & 3 & 0 \\
\hline $2331-2332$ & 21 & 6 & 0 & 6 & 2 & 0 \\
\hline $2334-2335$ & 6 & 2 & 0 & 7 & 0 & 1 \\
\hline $2336-2337$ & 10 & 4 & 1 & 6 & 4 & 0 \\
\hline $2338-2339$ & 15 & 2 & 4 & 6 & 4 & 6 \\
\hline $2340-2341$ & 6 & 6 & 1 & 4 & 1 & 0 \\
\hline $2342-2343$ & 8 & 4 & 2 & 5 & 1 & 1 \\
\hline $2344-2345$ & 13 & 3 & 2 & 5 & 1 & 0 \\
\hline
\end{tabular}

\subsection{Model Bldgs. 2338 and 2339}

The estimated total cost of demolition for the model building is \$200,717. The estimated duration for demolition is 35 days. Deconstruction costs are estimated at $\$ 211,300$. The estimated duration for deconstruction is 49 days. Demolition would take $71 \%$ of the time required for deconstruction. The income generated from salvage is estimated at $\$ 33,444$ for the materials in the model warehouse. Thus, the total net cost for deconstruction is $\$ 177,856$ (Table 4). This represents a savings over demolition.

\subsection{Remaining buildings}

Table 4 lists the demolition, deconstruction, and savings associated with salvage for all of the warehouse buildings in this investigation. These figures include a $25 \%$ contingency markup to account for fees or unexpected costs. The average cost of demolition per square foot is $\$ 15.10$ while the average cost for deconstruction per square foot is $\$ 16.17$. For deconstruction to be cost effective, the applicable items must be salvaged to offset the 
higher cost of deconstruction. The next chapter discusses the available markets for the materials recoverable from these warehouses.

Table 4. Summary of costs for all buildings.

\begin{tabular}{|c|c|c|c|}
\hline \multirow[b]{2}{*}{ Warehouses } & \multicolumn{3}{|c|}{ Costs } \\
\hline & Demolition & Deconstruction & $\begin{array}{c}\text { Deconstruction } \\
\text { with Savings }\end{array}$ \\
\hline 2303 & $\$ 30,303.66$ & $\$ 32,893.52$ & $\$ 25,354.59$ \\
\hline 2307 & $\$ 30,655.99$ & $\$ 32,696.62$ & $\$ 25,177.37$ \\
\hline 2308 & $\$ 387,932.49$ & $\$ 448,412.39$ & $\$ 372,803.96$ \\
\hline $2310-2311$ & $\$ 252,931.27$ & $\$ 269,826.32$ & $\$ 228,083.53$ \\
\hline $2313-2314$ & $\$ 249,604.49$ & $\$ 262,676.67$ & $\$ 221,015.86$ \\
\hline 2315 & $\$ 134,702.45$ & $\$ 137,093.35$ & $\$ 106,999.20$ \\
\hline 2318 & $\$ 134,879.58$ & $\$ 141,678.61$ & $\$ 99,634.34$ \\
\hline 2319-2320 & $\$ 260,497.41$ & $\$ 252,963.66$ & $\$ 209,980.54$ \\
\hline 2321-2322 & $\$ 302,240.41$ & $\$ 331,642.13$ & $\$ 274,826.66$ \\
\hline 2323-2324 & $\$ 249,795.34$ & $\$ 262,740.71$ & $\$ 221,073.50$ \\
\hline $2325-2326$ & $\$ 277,993.97$ & $\$ 304,783.04$ & $\$ 244,730.78$ \\
\hline 2330 & $\$ 137,924.29$ & $\$ 145,903.40$ & $\$ 127,188.83$ \\
\hline $2331-2332$ & $\$ 259,889.69$ & $\$ 270,843.65$ & $\$ 235,029.74$ \\
\hline $2334-2335$ & $\$ 249,240.10$ & $\$ 266,383.45$ & $\$ 212,860.36$ \\
\hline $2336-2337$ & $\$ 249,566.32$ & $\$ 266,936.92$ & $\$ 213,358.48$ \\
\hline $2338-2339$ & $\$ 250,896.87$ & $\$ 264,125.73$ & $\$ 222,320.02$ \\
\hline $2340-2341$ & $\$ 249,107.70$ & $\$ 261,842.91$ & $\$ 220,265.48$ \\
\hline $2342-2343$ & $\$ 283,792.21$ & $\$ 312,834.56$ & $\$ 257,159.41$ \\
\hline $2344-2345$ & $\$ 266,797.87$ & $\$ 293,076.58$ & $\$ 252,308.84$ \\
\hline Total & $\$ 4,259,257.10$ & $\$ 4,559,354.22$ & $\$ 4,559,354.22$ \\
\hline Average $\$ / \mathrm{ft}^{2}$ & $\$ 15.10$ & $\$ 16.17$ & $\$ 13.37$ \\
\hline
\end{tabular}




\section{Reuse}

\subsection{Exterior}

A number of the buildings' exterior elements identified in the previous chapters have the potential for reuse. The double-hung sash windows are all the same size and could serve their purpose adequately in an unconditioned space. They are certainly not energy efficient, nor easy to operate.

Single and double steel doors and their frames could be reused in new locations provided the door itself is in good condition. Doors that are dented or rusty should not be reused.

Window A/C units, ordinarily installed to condition office spaces, were common throughout the buildings. Although these units could be reused, it is unlikely that it would be worth the time or effort to save them. However, it would be sensible to save and store the more costly ground A/C units so they can be reinstalled in different locations. Moreover, many of these units appeared to be only a few years old and would likely have significant remaining lifespan.

\subsection{Interior}

Indoor fixtures also have potential for reuse. Bathroom fixtures that use hands free or motion detection are currently popular; sink faucets can be retrofitted with these upgrades so sinks in good condition can be reused. However, older ceramic toilets and urinals that use out of date flush valves have little reuse potential since it is unlikely that they can be retrofitted.

Only Bldg. 2308 contained showers, and these were the plastic type. There is no reason to reuse these.

The boilers in many of the buildings could be reused; however, since units like these have a limited lifespan and will eventually need to be replaced anyway, reuse may not be very cost effective.

The ceiling-mounted fan coil units in many of the warehouses are generally industrial-type heaters that, if serviced regularly, will last quite a while. These units could be moved, stored, and installed in new locations without much difficulty. 
The furnaces in many of the buildings could also be moved, stored, and installed in new locations with little difficulty. These small units would have to be used in a location appropriately sized for the unit.

The fluorescent light fixtures are standard and could be used anywhere needed. If nothing else, the bulbs themselves could be saved and used elsewhere. 


\section{Landfill, Transfer Station Services, and Salvage Markets}

\subsection{Landfill}

The local landfill nearest Fort Leonard Wood is the Black Oak Landfill. The landfill is located in Hartville, Missouri, approximately 60 miles from Fort Leonard Wood.

\subsection{Transfer station}

Although the Hartville landfill receives the bulk of the waste from the installation, the waste is first taken to the Saint Robert Transfer Station, 119 J.H. Williamson Drive, St. Robert, Missouri, approximately 10 miles from Fort Leonard Wood. The Saint Robert Transfer Station services the town of St. Robert, including hauling companies, businesses, and residents. Waste brought to the transfer station is consolidated and then transported to the Hartville Landfill, also located in Missouri, for disposal.

The transfer station offers recycling services for Pulaski County residents and maintains drop boxes for local residents for the disposal of

- recyclables,

- \#1 clear and \#2 opaque and colored plastics,

- tin and aluminum cans,

- office paper,

- newspaper,

- packing paper, and

- magazines and corrugated cardboard.

The recyclables are then sold to brokers for transport to different markets. The transfer station also accepts different types of e-waste including

- flat screen monitors,

- PCs,

- mice,

- laptops,

- keyboards,

- printers, and

- scanners and fax machines. 
For a fee, the transfer station offers document-shredding services. Finally, the transfer station operates a free household hazardous waste collection program for residential customers only. The transfer station is open Monday through Friday, 7:30 a.m. to 3:30 p.m.

\subsection{Salvage markets}

For deconstruction to be cost effective, markets must be identified for salvaged items, either for recycling or for resale. The categories of materials contained in these warehouse buildings is minimal, and the bulk of the material is wood and concrete. Table 5 lists contacts for various entities that accept materials generated during deconstruction.

Table 5. Contacts for various entities accepting the materials generated during deconstruction.

\begin{tabular}{|l|l|l|l|}
\hline Material & Company & Location & Contact \\
\hline Metal & Davis Metals \& Recycling & Rolla, MO & 573-364-2157 \\
\hline Wood & Antique-Wood & Kansas City, MO & 816-728-7300 \\
\hline Steel I-beams & Midwest Iron and Metal & Hutchinson, KS & $620-662-0551$ \\
\hline Concrete & Eco Recycling & St Louis, MO & $314-862-3335$ \\
\hline Concrete & M\&M Roll Off \& Sanitation & Crocker, MO & $573-736-5994$ \\
\hline Light Bulbs & Bulb Cycle & San Diego, CA & 858-412-6536 \\
\hline Fiberglass & American Fiber Green Products & Florida & 813-247-2770 \\
\hline Furnaces & Recycling Furnaces International & New York & 518-424-1168 \\
\hline Furnaces and Scrap Metal & Southern Metal Processing & St Louis, MO & $314-492-6944$ \\
\hline Acoustic Ceiling Tiles & Armstrong Ceilings & Lancaster, PA & $610-955-9900$ \\
\hline
\end{tabular}

\subsubsection{Metal}

Steel ductwork and aluminum siding, gutters, and downspouts can be taken to a scrap metal recycler. Metal doors, steel beams, steel roofing, steel siding, chain link fence, furnaces, boilers, and fire sprinkler system components can all be scrapped. Aluminum will yield a higher market value if clean. Note that scrap aluminum must contain no steel. Table 5 lists several entities that accept scrap metal.

\subsubsection{Concrete}

Concrete block and concrete footings can be crushed and reused. The removal costs are high, but the material has some salvage value. 


\subsubsection{Wood}

For wood to be acceptable, it must contain no nails. The value of the wood is determined either by square footage (for flooring) or by board feet (for dimensional lumber). Hauling and disposal costs are determined by weight using a standard density.

\subsubsection{Glass}

If the windows are not reused, they glass panes are considered waste and are disposed of by weight.

\subsubsection{Insulation}

The category of insulation includes drywall, gypsum board, fiberglass, and acoustic ceiling tiles. For these materials to be acceptable, they must not contain asbestos. The fiberglass insulation can be bailed into 40-ton truckloads.

\subsubsection{Bricks}

The firewall bricks have no salvage value.

\subsubsection{Asphalt shingles}

The asphalt shingles have no salvage value. 


\section{Cost Analysis}

Cost for removal of the building elements and materials quantified in the previous chapters is extrapolated out and presented as potential revenue amounts for the items salvageable. The analysis begins by gathering the total amount of each material for all the buildings. Table 6 lists the result.

Table 6. Total material quantities from all buildings.

\begin{tabular}{|c|c|c|}
\hline Material & $\begin{array}{l}\text { Total Bldg. } \\
\text { Quantities }\end{array}$ & Units \\
\hline \multicolumn{3}{|l|}{ 1. Wood } \\
\hline Maple Flooring & 264,480 & $\mathrm{ft}^{2}$ \\
\hline Siding & 95,004 & $\mathrm{ft}^{2}$ \\
\hline $2 \times 4 s$ & 78,329 & board foot \\
\hline $2 \mathrm{ft} \times 6 \mathrm{ft}$ Truss & 46,255 & board foot \\
\hline $6 \mathrm{ft} \times 6 \mathrm{ft} \mathrm{Beam}$ & 70,180 & board foot \\
\hline $2 \times 12 s$ & 396,720 & board foot \\
\hline \multicolumn{3}{|l|}{ 2. Scrap Metal } \\
\hline Double Doors & 21 & each \\
\hline Single Door & 65 & each \\
\hline Aluminum Siding & 103,704 & $\mathrm{ft}^{2}$ \\
\hline Roof (assuming light weight steel) & $72,079.88$ & $\mathrm{ft}^{2}$ \\
\hline Steel Beams W18 (assuming 18 in. $\times 6$ in.) & 430 & linear foot \\
\hline Steel Columns W8 (assuming 8 in. $\times 4$ in.) & 520 & linear foot \\
\hline Steel Columns W14 (assuming 14 in. $\times 5$ in.) & 1,040 & linear foot \\
\hline Steel Siding (assuming 26 gauge) & 17,200 & $\mathrm{ft}^{2}$ \\
\hline Chain Link (assuming $10 \mathrm{ft}$ high) & 5,250 & linear foot \\
\hline Furnaces & 25 & each \\
\hline Boilers & 25 & each \\
\hline Fire Sprinkler Lines & 3,148 & linear foot \\
\hline Window $\mathrm{A} / \mathrm{C}$ Unit & 25 & each \\
\hline Ground $\mathrm{A} / \mathrm{C}$ Unit & 14 & each \\
\hline \multicolumn{3}{|l|}{ 3. Structural Materials } \\
\hline Brick Chimney & 3,480 & $\mathrm{ft}^{2}$ \\
\hline Brick Wall & 27,840 & $\mathrm{ft}^{2}$ \\
\hline Concrete Blocks & 2,250 & $\mathrm{ft}^{2}$ \\
\hline Concrete Footings & 88,160 & $\mathrm{ft}^{2}$ \\
\hline Concrete Slab and Footings & 14,405 & $\mathrm{ft}^{2}$ \\
\hline
\end{tabular}




\begin{tabular}{|l|c|l|}
\hline Material & $\begin{array}{l}\text { Total Bldg. } \\
\text { Quantities }\end{array}$ & Units \\
\hline 4. Insulation & 101,474 & $\mathrm{ft}^{2}$ \\
\hline $\begin{array}{l}\text { Drywall (includes drywall, gypsum ceiling, } \\
\text { gypsum board \& partitions) }\end{array}$ & $335,786.5$ & $\mathrm{ft}^{2}$ \\
\hline Insulation (fiberglass) & 18,240 & $\mathrm{ft}^{2}$ \\
\hline Acoustic Ceiling Tiles & 2,563 & each \\
\hline 5. Miscellaneous & 208 & each \\
\hline Lights (4 ft ceiling fluorescent lights) & &
\end{tabular}

Next, the potential revenue is gathered. The categories that yielded revenue include wood and metal. The categories of structural materials, insulation, and miscellaneous did not generate any revenue. Table 7 lists the result. The total revenue was just over $\$ 1 \mathrm{M}$.

Table 7. Revenue from salvageable materials.

\begin{tabular}{|l|r|}
\hline Material & \multicolumn{1}{|l|}{ Revenue } \\
\hline 1. Wood & $\$ 396,720.00$ \\
\hline Maple Flooring & $\$ 4,914.00$ \\
\hline Siding & $\$ 70,062.13$ \\
\hline $2 \times 4 \mathrm{~s}$ & $\$ 41,369.71$ \\
\hline $2 \mathrm{ft} \times 6 \mathrm{ft}$ Truss & $\$ 32,280.62$ \\
\hline $6 \mathrm{ft} \times 6 \mathrm{ft}$ Beams & $\$ 506,885.43$ \\
\hline $2 \times 12 \mathrm{~s}$ & $\$ 118.37$ \\
\hline 2. Scrap Metal & $\$ 6.96$ \\
\hline Double Doors & $\$ 15,840.79$ \\
\hline Single Door & $\$ 3,784.19$ \\
\hline Aluminum Siding & $\$ 650.32$ \\
\hline Roof (assuming lightweight steel) & $\$ 247.07$ \\
\hline Steel Beams W18 (assuming 18 in. $\times 6$ in.) & $\$ 936.00$ \\
\hline Steel Columns W8 (assuming 8 in. $\times 4$ in.) & $\$ 192.64$ \\
\hline Steel Columns W14 (assuming 14 in. $\times 5$ in.) & $\$ 1,396.50$ \\
\hline Steel Siding (assuming 26 gauge) & $\$ 812.00$ \\
\hline Chain Link (assuming 10 ft high) & $\$ 210.00$ \\
\hline Furnaces & $\$ 881.44$ \\
\hline Boilers & $\$ 84.38$ \\
\hline Fire Sprinkler Lines & $\$ 506.25$ \\
\hline Window AC unit & \\
\hline Ground AC Unit & \\
\hline
\end{tabular}




\begin{tabular}{|l|l|}
\hline Material & \multicolumn{1}{|c|}{ Revenue } \\
\hline 3. Structural Materials & \\
\hline Brick Chimney & \\
\hline Brick Wall & \\
\hline Concrete Blocks & \\
\hline Concrete Footings & \\
\hline Concrete Slab and Footings & \\
\hline 4. Insulation & \\
\hline $\begin{array}{l}\text { Drywall (includes drywall, gypsum ceiling, gypsum board \& } \\
\text { partitions) }\end{array}$ & \\
\hline Insulation (fiberglass) & \\
\hline Acoustic Ceiling Tiles & \\
\hline 5. Miscellaneous & \\
\hline Lights (4 ft ceiling fluorescent lights) & $\$ 1,077,898.78$ \\
\hline Windows & \\
\hline TOTAL & \\
\hline
\end{tabular}

Next, the cost for disposal was gathered. It is assumed that there is no removal cost for salvageable items since the salvaging entity would bear that cost. The landfill tipping fee is included for all materials so that if no items of a specific type are salvaged, the tipping fee will represent the maximum disposal cost for that particular item.

A national average cost to remove and the local market cost to remove have been provided for several of the items. The landfill tipping fees are drawn from the nearest landfill (i.e., the cost for items taken to the Hartville Landfill from the St. Roberts Transfer Station). Table 8 lists the removal costs. The total cost to remove the materials including the landfill tipping fees is approximately $\$ 430,000$.

Note that, as more materials are salvaged, the cost to dispose will decrease and vice versa. 
Table 8. Cost to dispose of materials.

\begin{tabular}{|c|c|c|c|}
\hline Material & $\begin{array}{c}\text { Disposal Cost } \\
\text { in } \\
\text { the United } \\
\text { States }\end{array}$ & $\begin{array}{c}\text { Disposal Cost } \\
\text { in } \\
\text { St. Roberts }\end{array}$ & $\begin{array}{l}\text { Landfill Tip Fee St. Roberts } \\
\text { (\$50/ton) }\end{array}$ \\
\hline \multicolumn{4}{|l|}{ 1. Wood } \\
\hline Maple Flooring & & & $-\$ 26,448$ \\
\hline Siding & & & $-\$ 442$ \\
\hline $2 \times 4 s$ & & & $-\$ 5,004$ \\
\hline $2 \mathrm{ft} \times 6 \mathrm{ft}$ Truss & & & $-\$ 2,955$ \\
\hline $6 \mathrm{ft} \times 6 \mathrm{ft}$ Beams & & & $-\$ 5,559$ \\
\hline $2 \times 12 \mathrm{~s}$ & & & $-\$ 25,344$ \\
\hline \multicolumn{4}{|l|}{ 2. Scrap Metal } \\
\hline Double Doors & & & $-\$ 85$ \\
\hline Single Door & & & $-\$ 5$ \\
\hline Aluminum Siding & & & $-\$ 843$ \\
\hline Roof (assuming light weight steel) & & & $-\$ 2,703$ \\
\hline Steel Beams W18 (assuming 18 in. $\times 6$ in.) & & & $-\$ 434$ \\
\hline Steel Columns W8 (assuming 8 in. $\times 4$ in.) & & & $-\$ 165$ \\
\hline Steel Columns W14 (assuming 14 in. $\times 5$ in.) & & & $-\$ 624$ \\
\hline Steel Siding (assuming 26 gauge) & & & $-\$ 96$ \\
\hline Chain Link (assuming $10 \mathrm{ft}$ high) & & & $-\$ 998$ \\
\hline Furnaces & & & $-\$ 580$ \\
\hline Boilers & & & $-\$ 150$ \\
\hline Fire Sprinkler Lines & & & $-\$ 630$ \\
\hline Window AC Unit & & & $-\$ 31$ \\
\hline Ground AC Unit & & & $-\$ 188$ \\
\hline \multicolumn{4}{|l|}{ 3. Structural Materials } \\
\hline Brick Chimney & & & $-\$ 223$ \\
\hline Brick Wall & & & $-\$ 1,300$ \\
\hline Concrete Blocks & $-\$ 140$ & $-\$ 1,688$ & $-\$ 5,625$ \\
\hline Concrete Footings & $-\$ 5,622$ & $-\$ 68,010$ & $-\$ 226,700$ \\
\hline Concrete Slab and Footings & $-\$ 893$ & $-\$ 10,804$ & $-\$ 36,013$ \\
\hline \multicolumn{4}{|l|}{ 4. Insulation } \\
\hline $\begin{array}{l}\text { Drywall (includes drywall, gypsum ceiling, gypsum } \\
\text { board \& partitions) }\end{array}$ & & & $-\$ 5,074$ \\
\hline Insulation (fiberglass) & $-\$ 2,000$ & & $-\$ 2,000$ \\
\hline Acoustic Ceiling Tiles & $\$ 0$ & & $-\$ 319$ \\
\hline \multicolumn{4}{|l|}{ 5. Miscellaneous } \\
\hline Lights ( $4 \mathrm{ft}$ ceiling fluorescent lights) & $-\$ 3,015$ & $-\$ 1,640$ & $-\$ 41$ \\
\hline Windows & & $-\$ 88$ & $-\$ 156$ \\
\hline TOTAL & $-\$ 11,670$ & $-\$ 82,230$ & $-\$ 350.733$ \\
\hline
\end{tabular}




\section{Conclusions and Recommendations}

\subsection{Conclusions}

This work concludes that the buildings in the Fort Leonard Wood warehouse district have great potential for deconstruction. The primary material available for recovery or reuse is wood structural members since

- The warehouses were constructed using a utilitarian facility-type design (i.e., little finish material was applied to the building components), such that reclaiming and reusing the (predominantly wood) components will be relatively easy.

- The warehouses show no signs of leakage so that the majority of wood appears to be in sound condition.

- The good condition of the wood members will allow the structures to be disassembled without causing substantial damage to the members despite the nailed connections.

- The tongue-and-groove maple hardwood flooring is very likely to attract interested purchasers with minimal marketing.

Other considerations include

- Given the age of the facility, it is likely that some painted components may contain lead-based paint. It would be prudent to account for proper disposal when planning a deconstruction project/contract.

- The economy of deconstruction would be greater if multiple warehouses were removed simultaneously under the same contract.

- Sheathing and other exterior envelope components were not visible during inspection, so the condition is unknown.

- A formal asbestos survey was not conducted; however, no asbestos was observed.

This work analyzed the relative costs of demolition, deconstruction, and deconstruction with savings. It is concluded that deconstruction with savings is more cost effective than either demolition or deconstruction. The costs of deconstruction with savings were approximately $\$ 489,086$ less than those of demolition and approximately $\$ 789,183$ less than those of deconstruction without savings. 
Furthermore, the results of the economic analysis indicate that if at least $\$ 430,000$ (of a possible $\$ 1,000,000$ ) worth of materials can be salvaged and sold, then the process will have recovered the cost of removal. Note that this analysis includes only the cost to remove the materials from the site; it does not include the cost of deconstruction.

\subsection{Recommendation}

This work recommends that the buildings in the warehouse district be deconstructed and salvaged of as much material as possible. This recommendation is supported by the following findings:

- The savings associated with the deconstruction and salvage process will reduce and may entirely cover the additional expense of deconstruction.

- Any materials salvaged will reduce the amount of materials going to the landfill, thereby reducing removal costs.

- Evaluation of the design, construction, and condition of the buildings in the Fort Leonard Wood warehouse district indicates that the buildings can be easily deconstructed and will yield a few categories of materials.

- The simple design of these buildings simplifies the deconstruction techniques needed to disassemble the structures and eases the recovery of salvageable materials.

- Access to the buildings is straightforward, and several salvage markets are nearby. 


\section{Unit Conversion Factors}

\begin{tabular}{|l|l|l|}
\hline \multicolumn{1}{|c|}{ Multiply } & \multicolumn{1}{c|}{ By } & \multicolumn{1}{c|}{ To Obtain } \\
\hline cubic feet & 0.02831685 & cubic meters \\
\hline feet & 0.3048 & meters \\
\hline inches & 0.0254 & meters \\
\hline miles (U.S. statute) & $1,609.347$ & meters \\
\hline square feet & 0.09290304 & square meters \\
\hline square inches & 6.4516 E-04 & square meters \\
\hline
\end{tabular}




\section{Appendix A: Detailed Assessment of Bldgs. 2310-2311}

\section{A.1 General}

Bldgs. 2310 and 2311 (Figure A-1) are general-purpose warehouses in an active material distribution facility. The building is actually a single structure separated at the middle by a brick firewall, each half designated by its own building number. Each half the building is about $150 \mathrm{ft}$ long and $60 \mathrm{ft}$ wide; together they have an interior floor area of $9,000 \mathrm{ft}^{2}$ and an exterior footprint of $9,200 \mathrm{ft}^{2}$. These are considered the common dimensions and configuration of the buildings detailed in this report. Both halves of the warehouse have small interior rooms. In Bldg. 2310, the interior rooms were clearly added after the building's initial construction. However, in Bldg. 2311, the entry seems to have been part of the building's initial construction, since it is of the same form and materials as the exterior walls.

Figure A-1. Bldg. 2311.

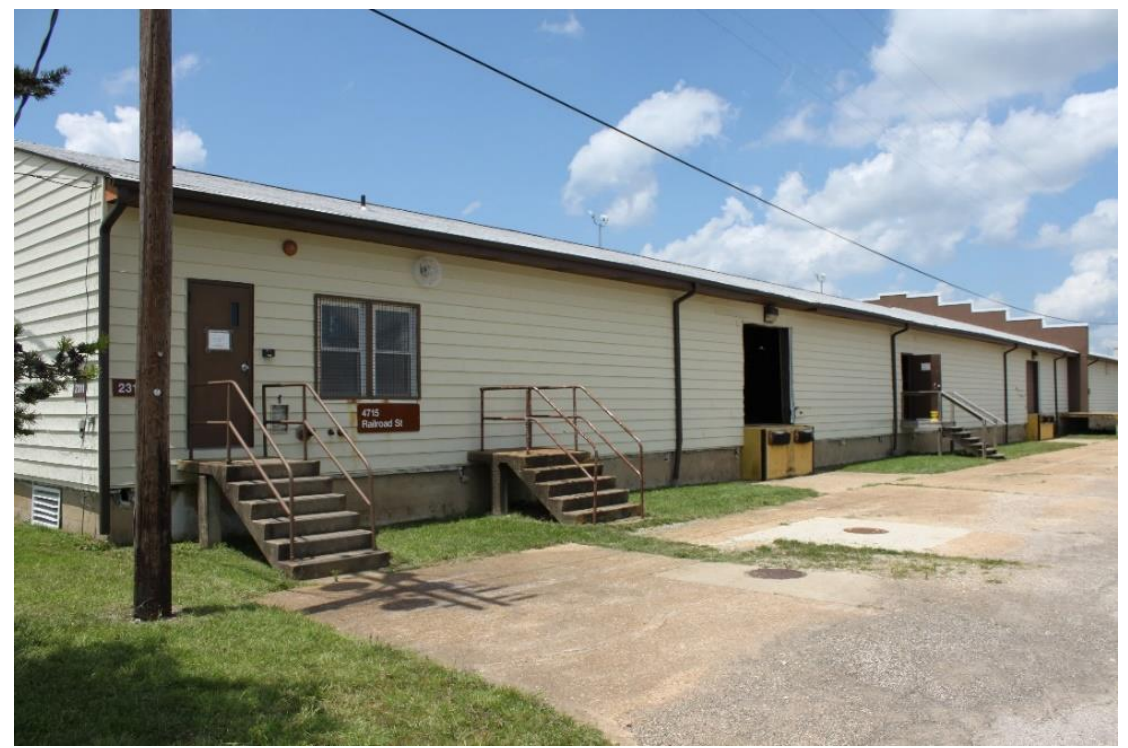




\section{A.2 Site}

The building is close to and is easily accessed from the nearby roads. The surrounding area provides prime locations for equipment and material storage. The areas adjacent to the building afford little room for tall or large equipment since the east and west faces of the building are boxed in by railroad tracks and power lines (Figure A-2). The area is generally level and should provide a fair amount of space for deconstruction.

The concrete loading docks on the back side of the warehouse, which are in good repair, are no longer in service. A $50 \mathrm{ft}$ long by $6.75 \mathrm{ft}$ wide wooden deck on the front of the Bldg. 2310 side of the building (Figure A-3) has an (assumed) aluminum covering.

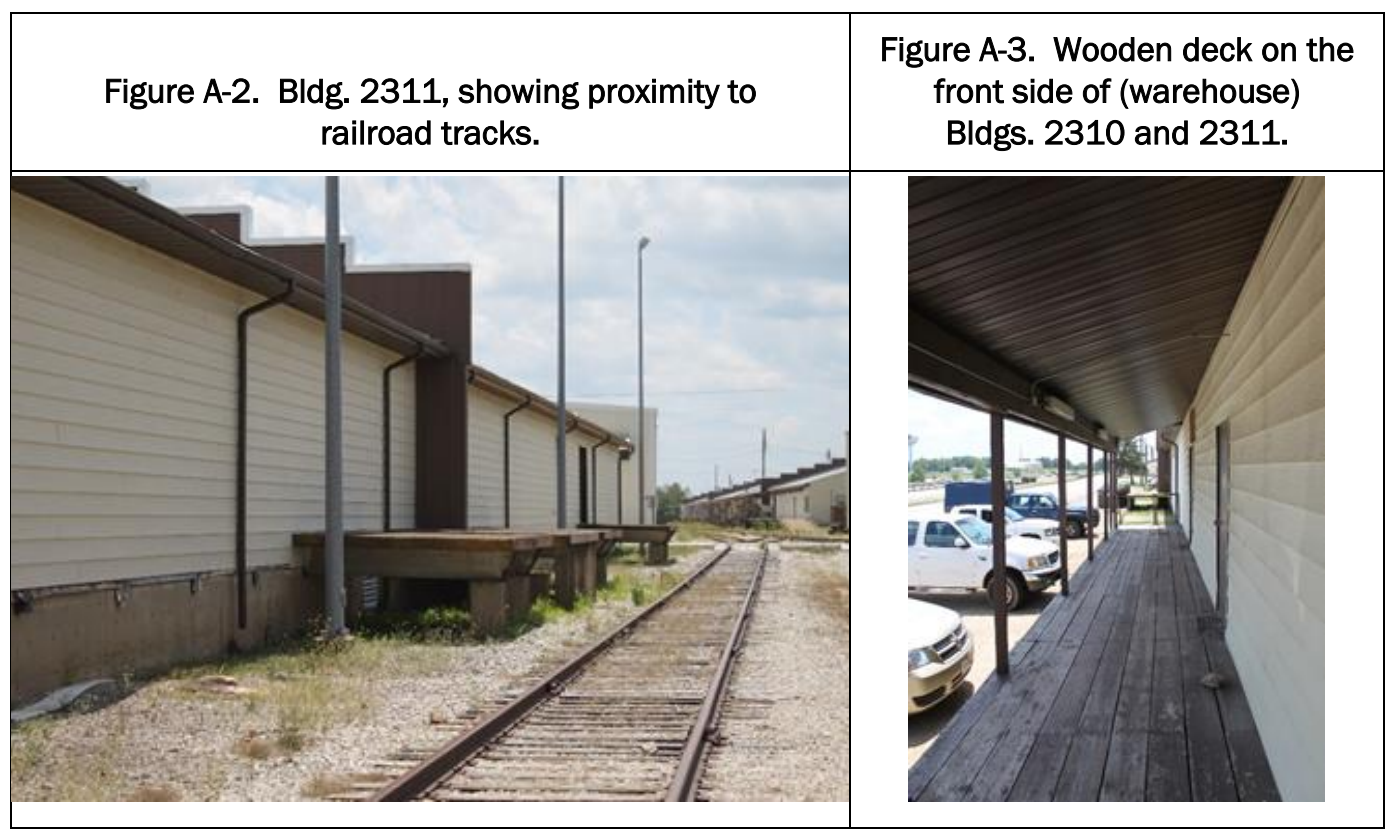

\section{A.3 Foundation}

The foundation is composed of five continuous footings running along the length of the facility and a continuous flooring at each end. The footings are 12 in. thick by $16 \mathrm{in}$. wide, and the walls of the flooring are $8 \mathrm{in}$. wide. The foundation walls are relatively tall to allow the finished floor elevations to reach railroad train car height. The footing depth is assumed to be at the frost depth (24 in. to 36 in.). 


\section{A.4 Structure}

The floor system is supported by 2 in. $\times 12$ in. joists spaced at 12 in. on center, spanning the foundation walls. The joists bear on 2 in. $\times 6$ in. sill plates and 2 in. $\times 12$ in. band joists that run the length of the building along the exterior walls. It is assumed that the condition of this subflooring is similar to that of Bldgs. 2338 and 2339. Signage posted in the building (Figure A-4) indicates that the floor can support $192.5 \mathrm{lb} / \mathrm{ft}^{2}$.

Figure A-4. Labeled load limit of Bldgs. 2310 and 2311 floor.

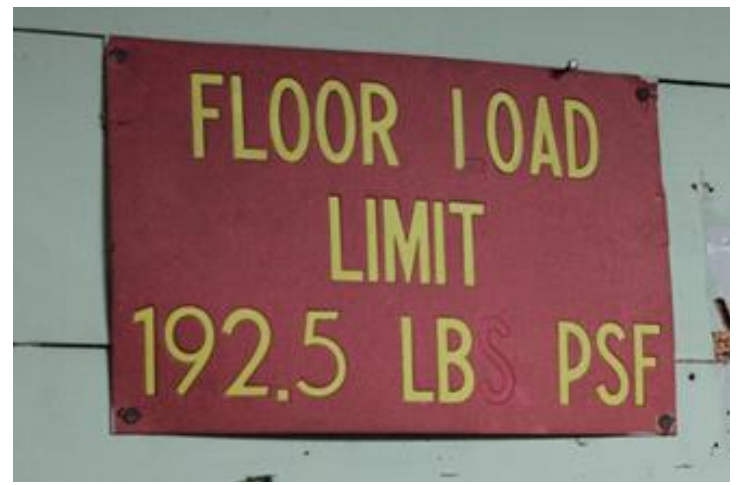

Vertical loads are supported by 6 in. $\times 6$ in. columns on a $9 \mathrm{ft} \times 12 \mathrm{ft}$ grid. Columns are braced both laterally and longitudinally by 2 in. $\times 6$ in. braces. An estimated 150 braces range from $9 \mathrm{ft}$ to $16 \mathrm{ft}$ in length. Columns carry two $2 \times 12 \mathrm{~s}$ at each row along the length of the building. There are 60 columns throughout one-half of the building at heights of $16 \mathrm{ft}$ and $12 \mathrm{ft}$. Connections are nailed, not bolted.

The roof system is comprised of 2 in. $\times 8$ in. rafters spaced 24 in. on center, spanning the ridge to the exterior walls. Roof decking is comprised of 8 in. wide boards installed perpendicular to the rafters.

The total structural wood available (Figure A-5) for recovery is approximately 40,00o board ft. 
Figure A-5. Structural wood available for recovery.

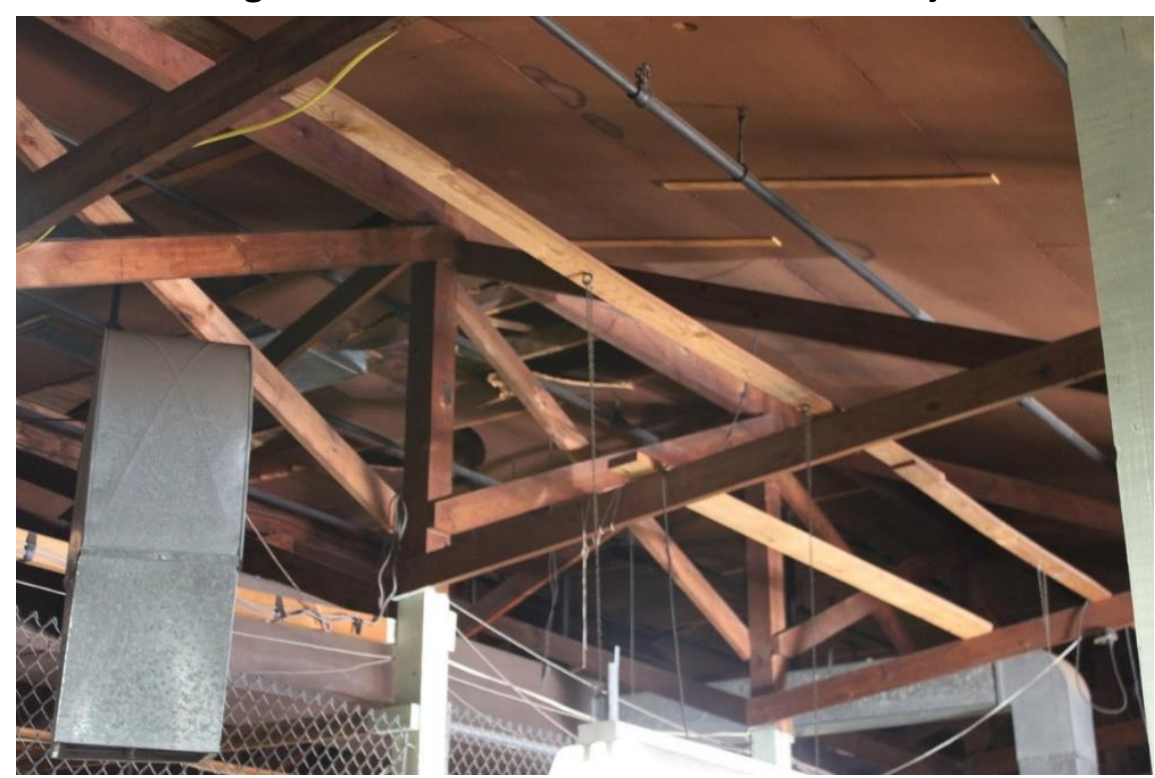

\section{A.5 Exterior enclosure}

The roof is a simple gable design with a 4:12 pitch. The roof wear surface is composed of asphalt three-tab shingles. The exterior walls are framed with 2 in. $\times 6$ in. studs, 24 in. on center, $9 \mathrm{ft}$ high. There are two top plates at both the top and bottom of the walls. A 2 in. $\times 6$ in. toe plate is installed at the bottom of the exterior walls. Horizontal boards are applied between the studs of the wall. The walls are sheathed with 6 in. boards applied diagonally.

The siding is thought to be steel, which depending on the condition, may be reusable; if not reusable, it can be recycled. The gutters and the underside of the deck awning are aluminum and can be recycled.

The roof shows signs of water leaks, and many sections have been patched or replaced (Figure A-6). Based on this observation, it is assumed that some of the roof decking may not be in reusable condition. 
Figure A-6. Roof section showing patches and repairs.

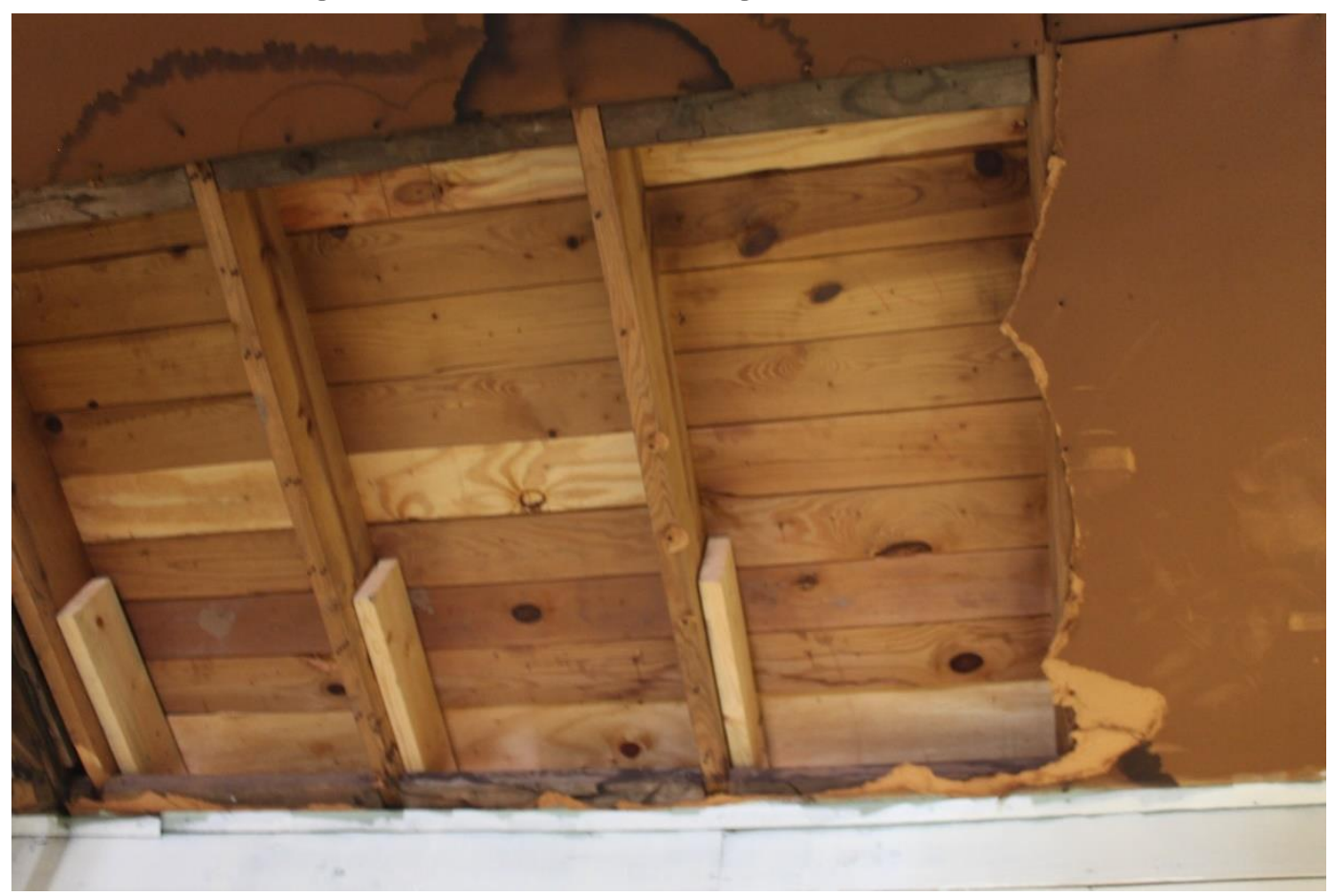

The eaves and rakes of the gable ends are finished with aluminum soffit and fascia, which are recyclable. This, along with approximately $1,100 \mathrm{ft}^{2}$ of soffit and fascia and $300 \mathrm{ft}^{2}$ of aluminum material covering the fire walls, will yield approximately $700 \mathrm{lb}$ of recyclable aluminum.

Bldg. 2310 has four 30 in. $\times 54$ in. exterior windows. Bldg. 2311 has three exterior windows of the same dimensions. These aluminum double-hung replacement-style windows would be suitable for reuse in nonconditioned spaces.

Bldg. 2310 has two $8 \mathrm{ft} \times 8 \mathrm{ft}$ overhead metal doors, both in serviceable, reusable condition, and four $30 \mathrm{in} . \times 80$ in. single exterior doors, also in good condition. Bldg. 2311 has three overhead doors and two single exterior doors in the same condition (Figure A-7). 
Figure A-7. Single exterior door, in good condition.

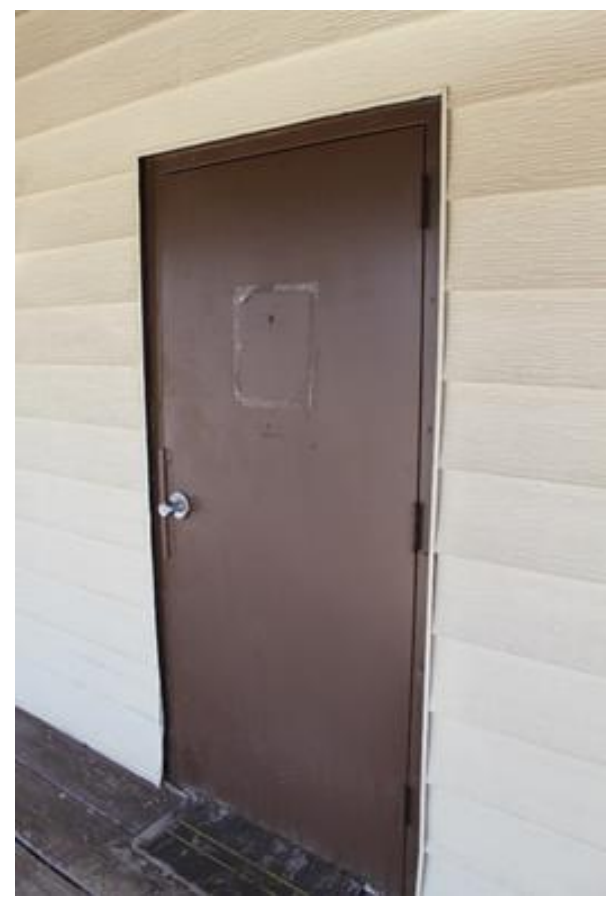

\section{A.6 Interior construction}

The interior construction of the warehouses is similar to that of all the buildings in the area: wood stud walls, vertical support beams, and rafters with fiberglass insulation. Some buildings have bathrooms and office spaces closed off by interior walls. A majority of the space is left to open storage with only vertical columns to break up the area.

Bldg. 2310 has six interior wooden doors and one interior window with solid pane glass. Bldg. 2311 has two lightweight, hollow-core, interior doors that are not in reusable condition.

The two halves of the warehouse are separated by a brick firewall; two large corrugated metal doors on either side of the firewall (Figure A-8) allow passage through the center of the building. The doors are in good condition and have potential for reuse. 
Figure A-8. Corrugated metal doors on either side of the fire wall.

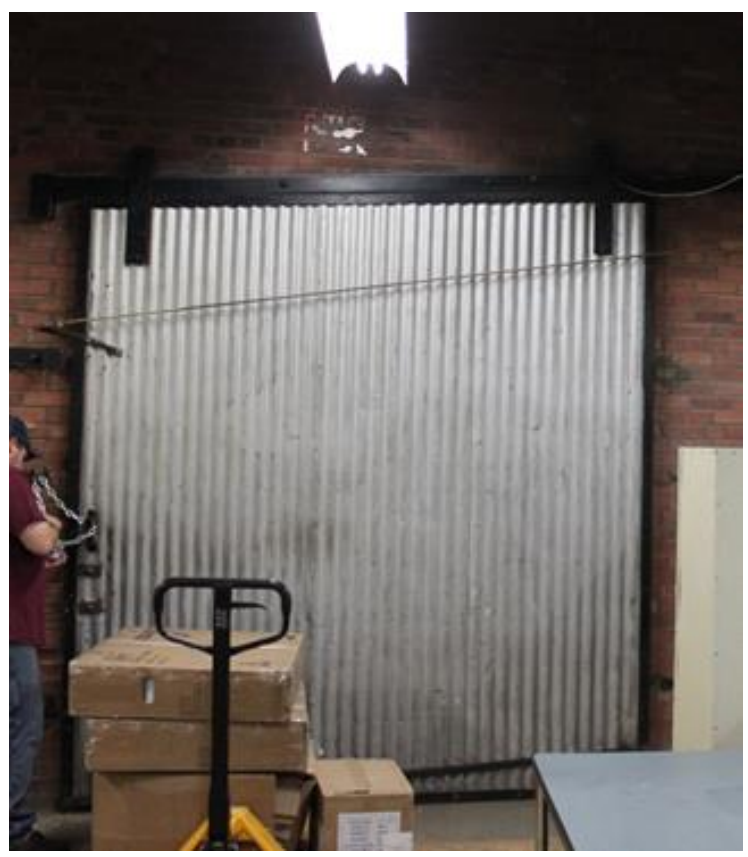

The flooring in Bldg. 2310 is covered with plywood and linoleum. The plywood is in poor condition and the top layer of linoleum is suspected to contain asbestos. In Bldg. 2311, the flooring consists of diagonal maple boards in moderate condition with sporadic gouges in high traffic areas (Figure A-9). Nevertheless, much of the floor remains serviceable and can be reclaimed (Figure A-10).

The walls in Bldg. 2310 are covered with about 4,800 $\mathrm{ft}^{2}$ of 6 in. wood paneling (Figure A-11). A smaller section of the walls in Bldg. 2311 is covered with about $1,100 \mathrm{ft}^{2}$ of the same paneling. The rest of the framing is estimated to consist of

- Rafters: 4,200 board ft,

- Walls (studs):1,200 board ft,

- Trusses: 3,200 board ft,

- Support columns: 4,80o board ft, and

- Floor joists: 27,00o board ft. 
Figure A-9. Flooring with sporadic gouges in high traffic areas.

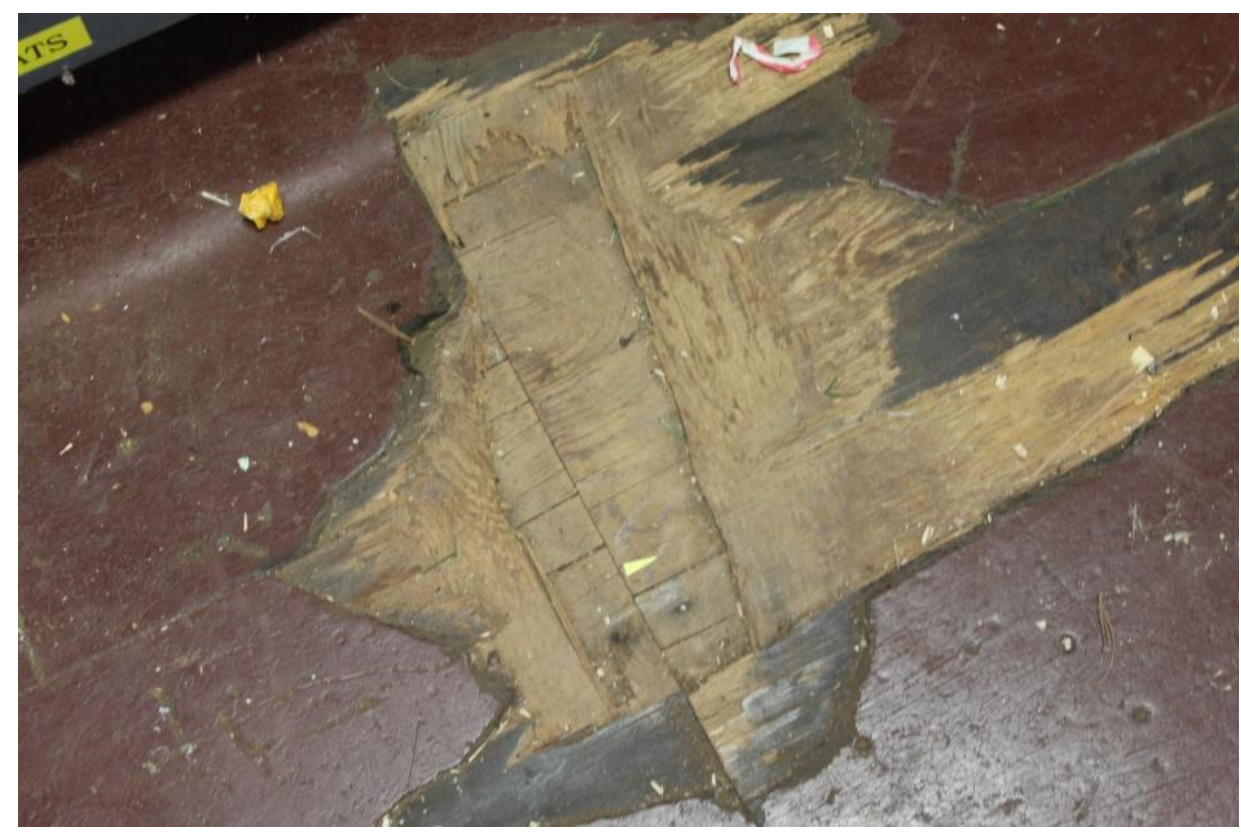

Figure A-10. Flooring in serviceable condition that can be reclaimed.

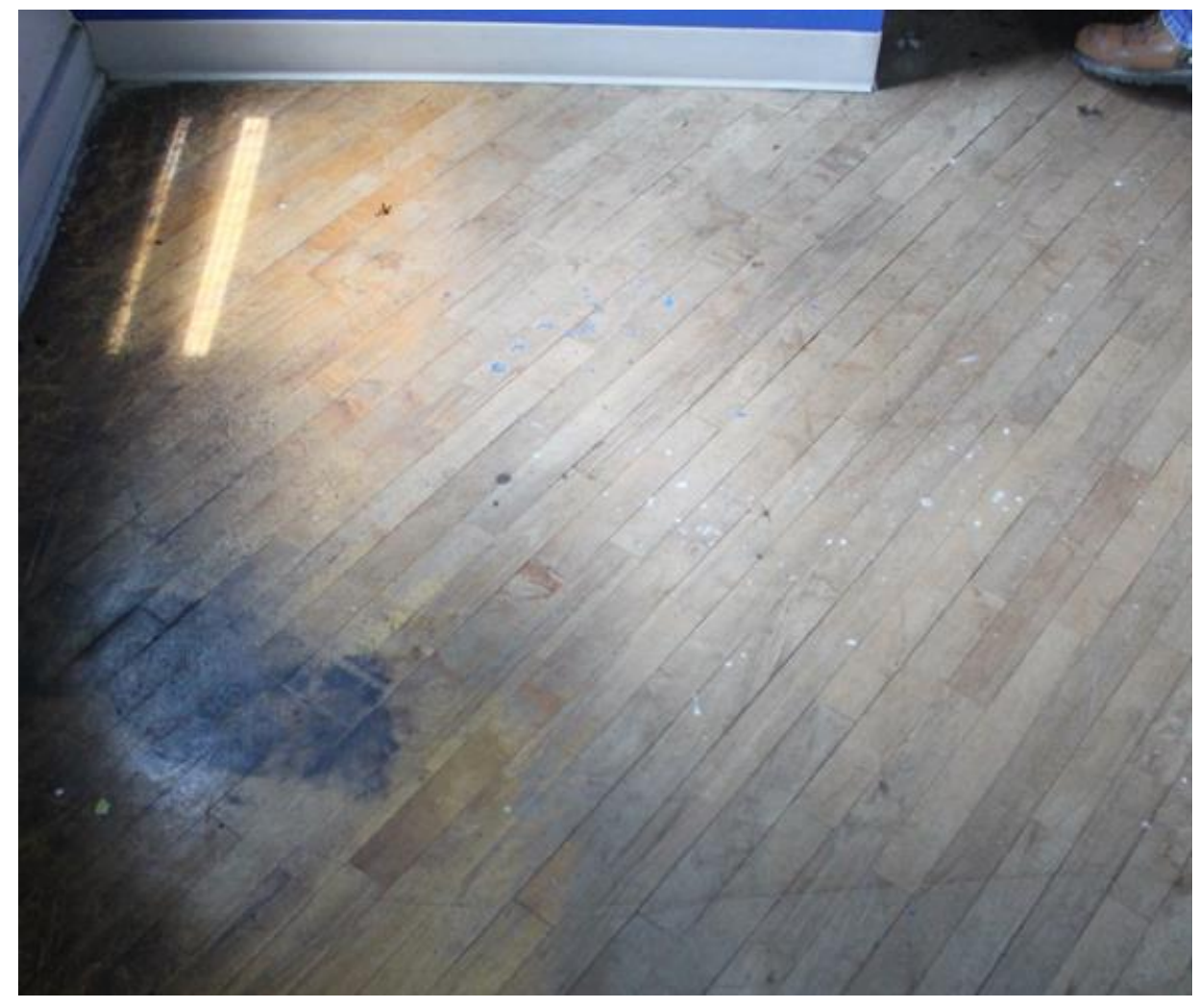


Figure A-11. Wood paneling.

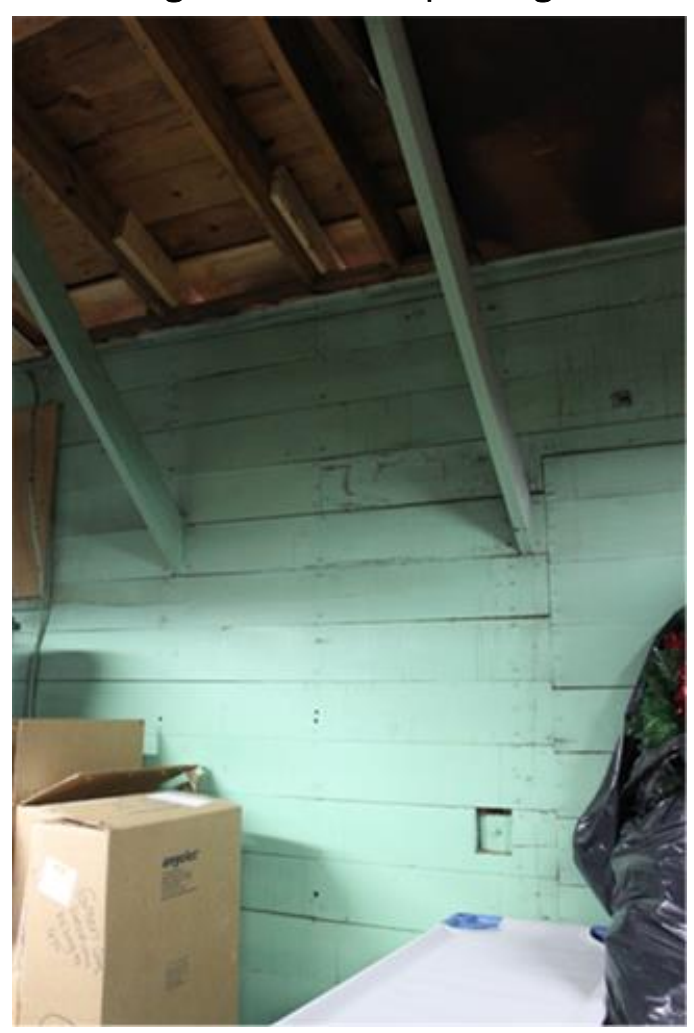

\section{A.7 Plumbing}

The Bldg. 2310 half of the building contains one set of bathrooms. Each bathroom contains one toilet and one sink. The sinks (Figures A-12 and A-13) are in reasonable condition and could be reused in another location. However, the toilets, which have old-style flush valves, are unlikely to be reusable. An unknown amount of iron pipe feeds both bathrooms.

Figure A-12. Bathroom sink console.

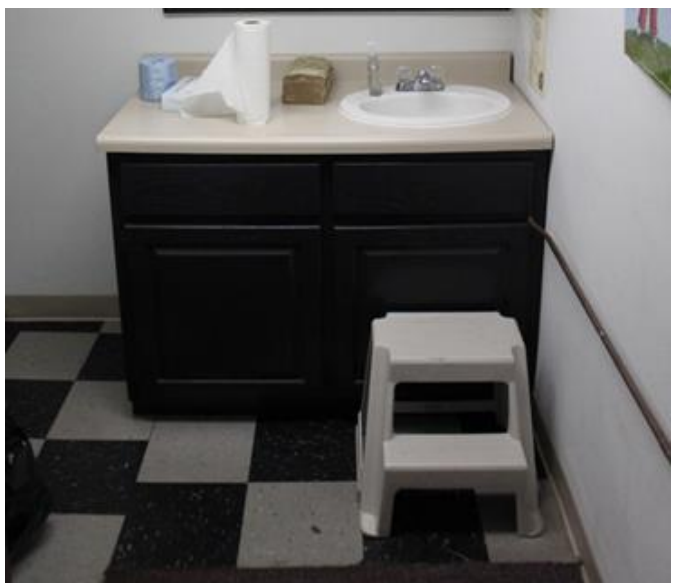

Figure A-13. Standalone bathroom sink.

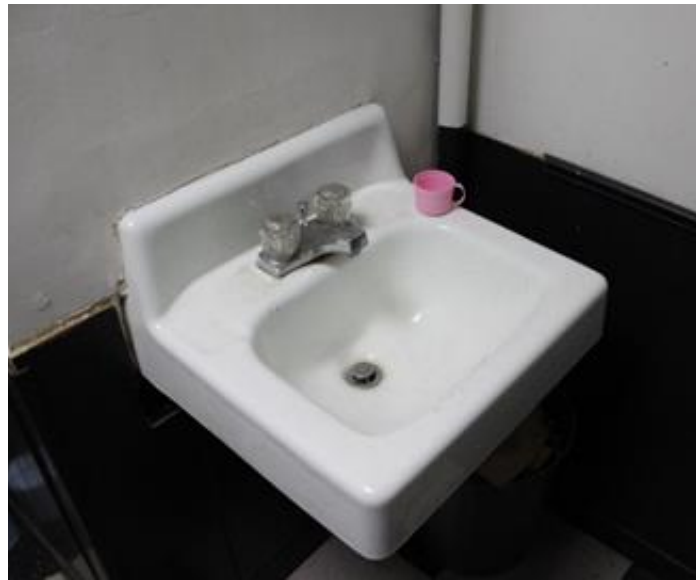




\section{A.8 Mechanical}

Only the Bldg. 2310 side of the building has mechanical equipment: two furnaces and one air-conditioner (Figure A-14). All are in fair condition and could be reused in similar environments. The larger furnace, a GMH8 Goodman product (Figure A-15) located in the mechanical room, services the storage section of the warehouse via an estimated $120 \mathrm{ft}$ of ductwork ranging from $2 \mathrm{ft}^{2}$ down to $18 \mathrm{in}^{2}$. There is also a brick chimney about $20 \mathrm{ft}$ tall and $3 \mathrm{ft}^{2}$. A smaller furnace (a Ck24-18 Goodman product) and an A/C unit service the office area (Figure A-16).

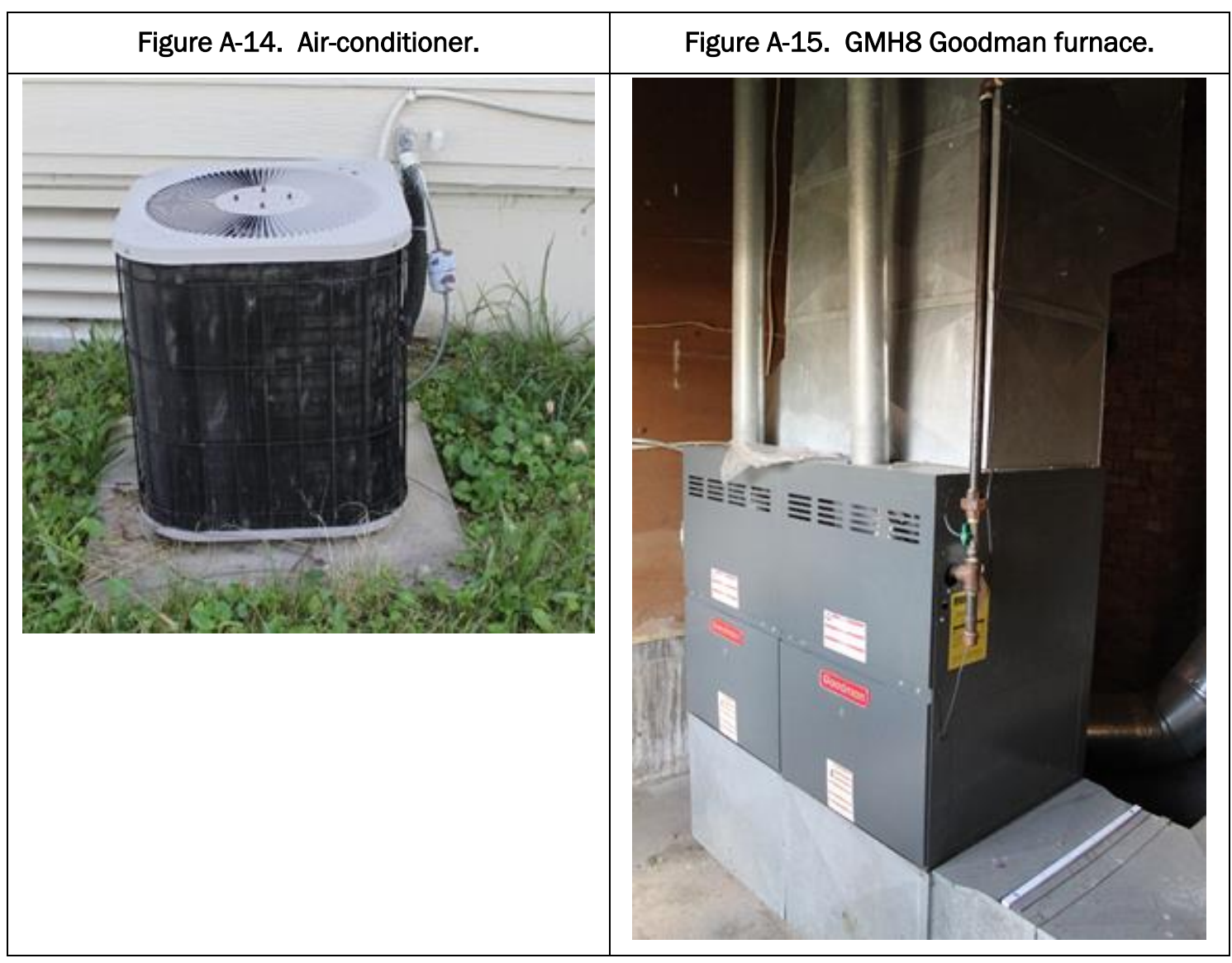


Figure A-16. Ck24-18 Goodman furnace.

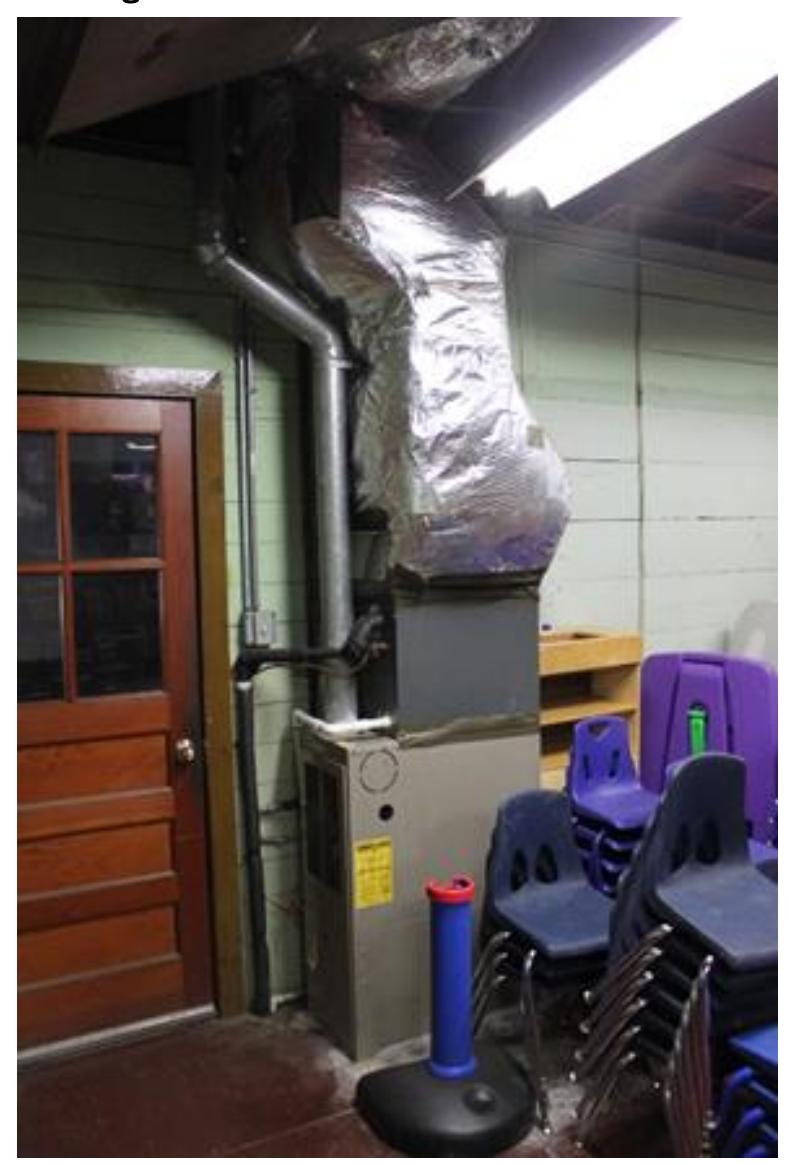

\section{A.9 Electrical}

The main storage area in both sides of the building is lit by $4 \mathrm{ft}$, 2-tube industrial ceiling-hung fluorescent lights spaced along the length of the structure (Figure A-17). There are 50 such fixtures in Bldg. 2310 and 75 in Bldg. 2311. There are also 14 square, $2 \mathrm{ft} \times 2 \mathrm{ft}$, lights in the office area and bathrooms of Bldg. 2310.

A small amount of electrical conduit was found in Bldg. 2310. All electrical paneling and boxes are easily accessed and in fair condition, though they will need updated breakers for reuse (Figure A-18). 
Figure A-17. Industrial ceiling-hung $4 \mathrm{ft}$, 2-tube fixtures.

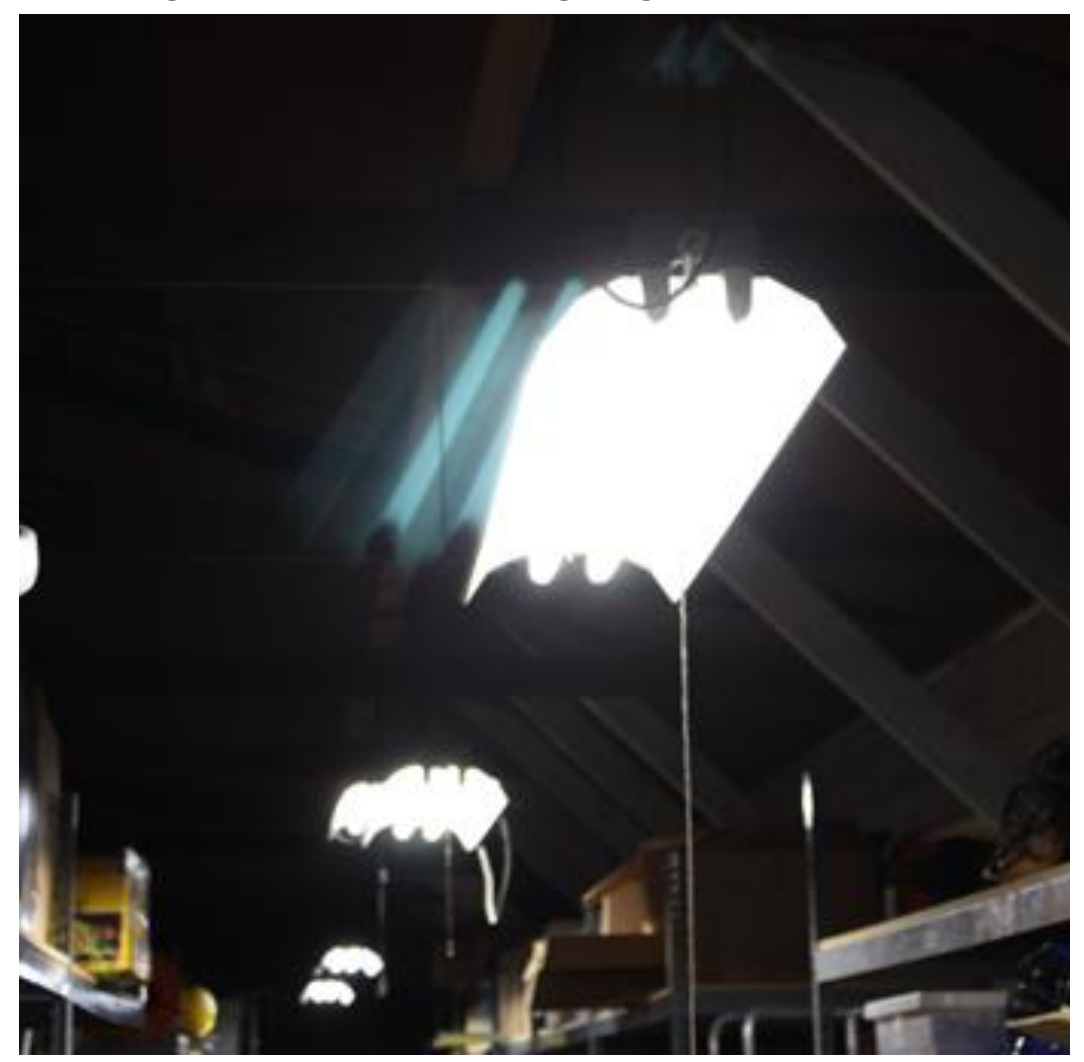

Figure A-18. Accessible electrical boxes.

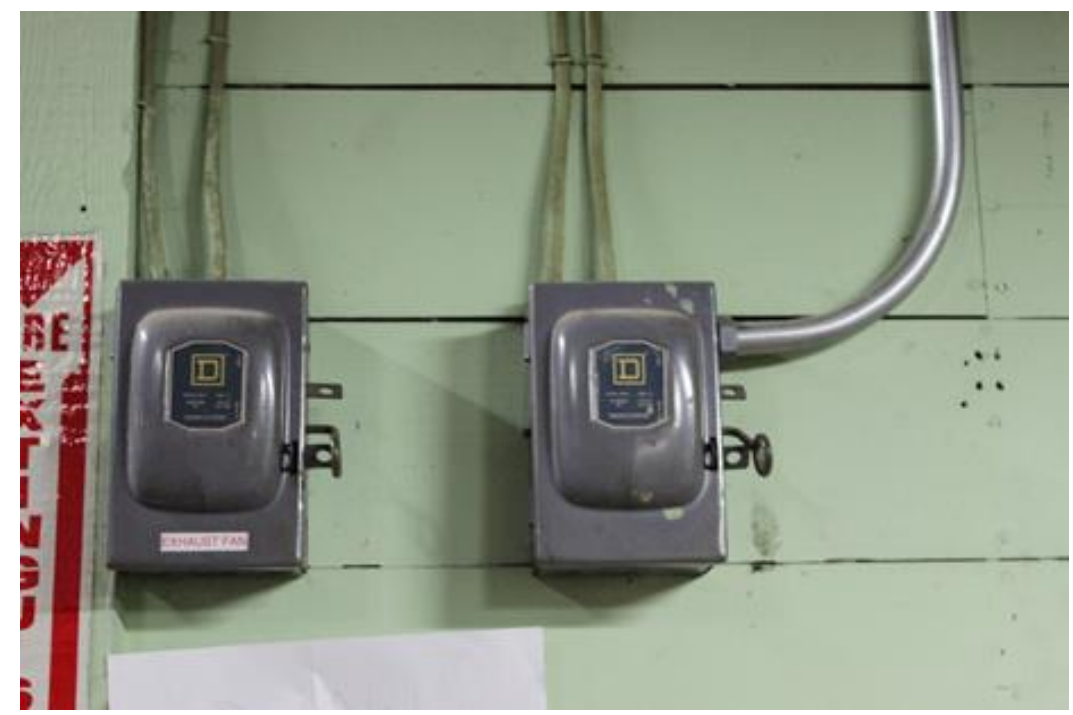

\section{A.10 Sprinkler systems}

Both halves of the building have a sprinkler pipe network (Figure A-19). It is likely that the piping in Bldg. 2311, which is composed of galvanized 
threaded pipe, has been replaced. The piping in Bldg. 2310, which is composed of black iron threaded pipe, is probably part of the original construction. Table A-1 summarizes the type and quantity of sprinkler pipe in Bldgs. 2310 and 2311.

Table A-1. Type and quantity of sprinkler pipe in Bldgs. 2310 and 2311.

\begin{tabular}{|c|c|c|}
\hline Bldg. & Pipe Size & Quantity \\
\hline \multirow{3}{*}{2310} & 1 to $2 \mathrm{in.}$ & $750 \mathrm{ft}$ \\
\cline { 2 - 3 } & $4 \mathrm{in.}$ & $100 \mathrm{ft}$ \\
\cline { 2 - 3 } & $6 \mathrm{in.}$ & $100 \mathrm{ft}$ \\
\hline \multirow{2}{*}{2311} & 1 to $1.5 \mathrm{in}$. & $300 \mathrm{ft}$ \\
\cline { 2 - 3 } & 4 in. & $400 \mathrm{ft}$ \\
\hline
\end{tabular}

There is a standpipe for each separate system (Figures A-2O and A-21), each isolated in a constructed room inside the warehouse.

Figure A-19. Pipe network for the sprinklers.

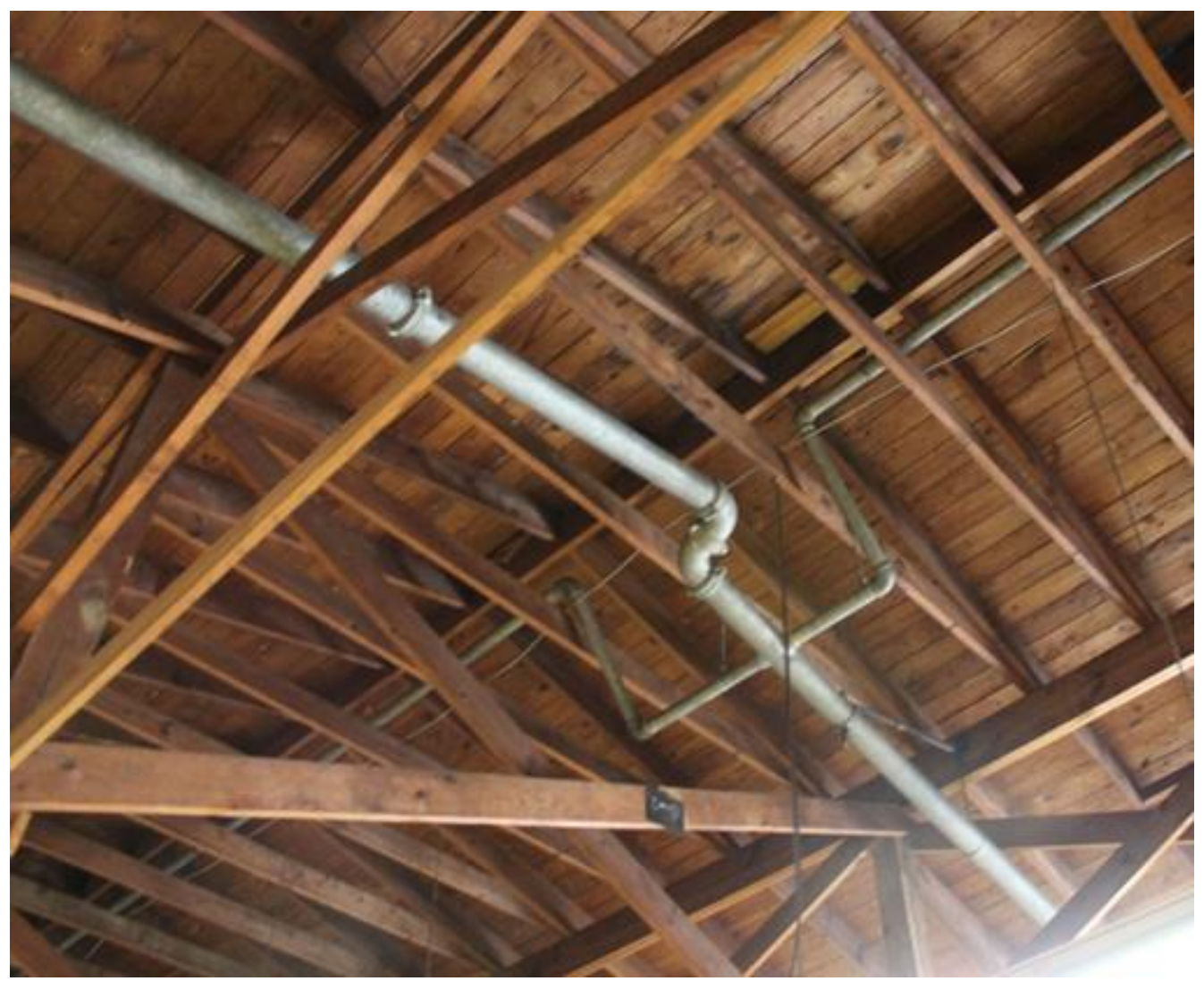


Figure A-20. Pipe valve for sprinkler system.

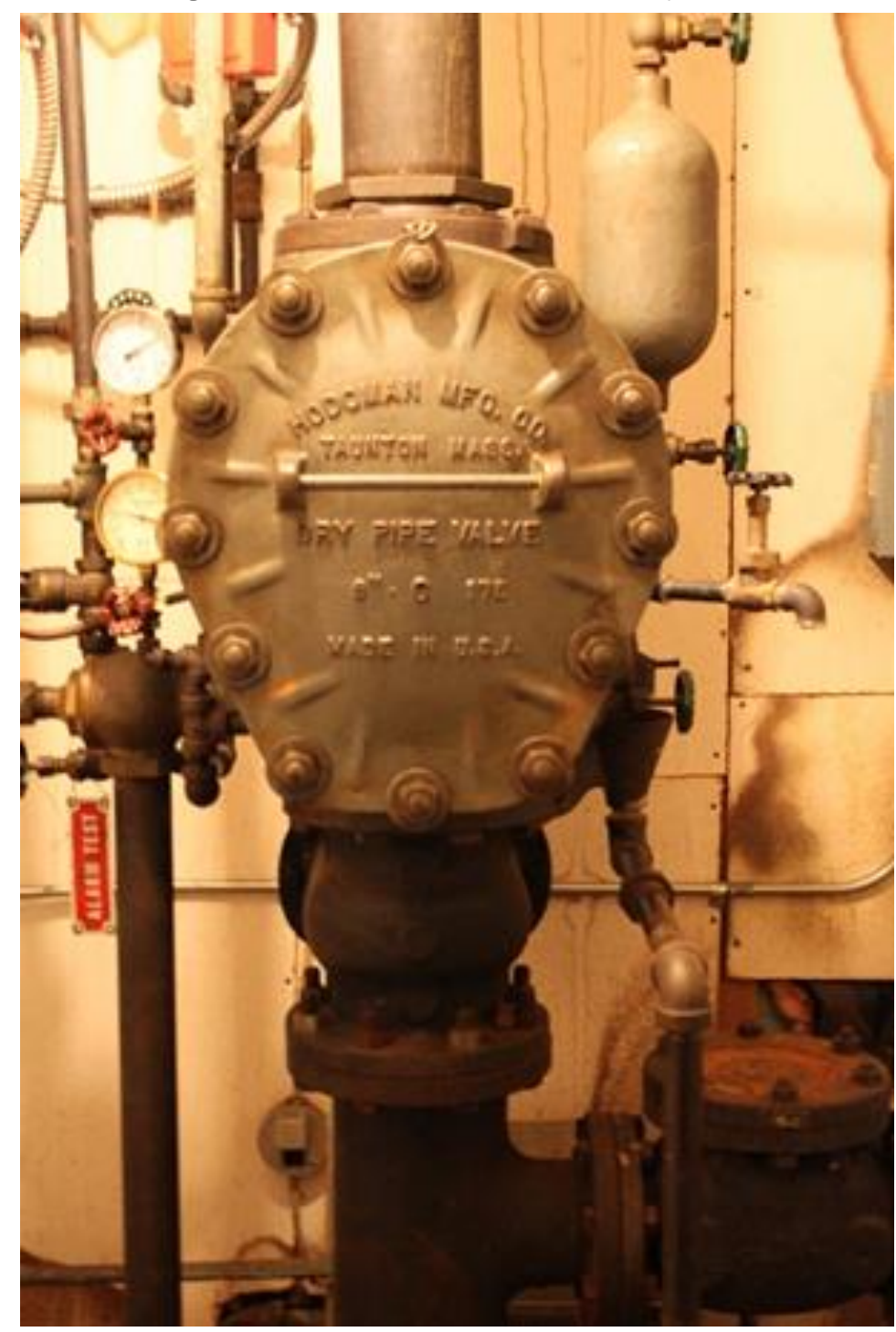

Figure A-21. Standpipe for sprinkler system.

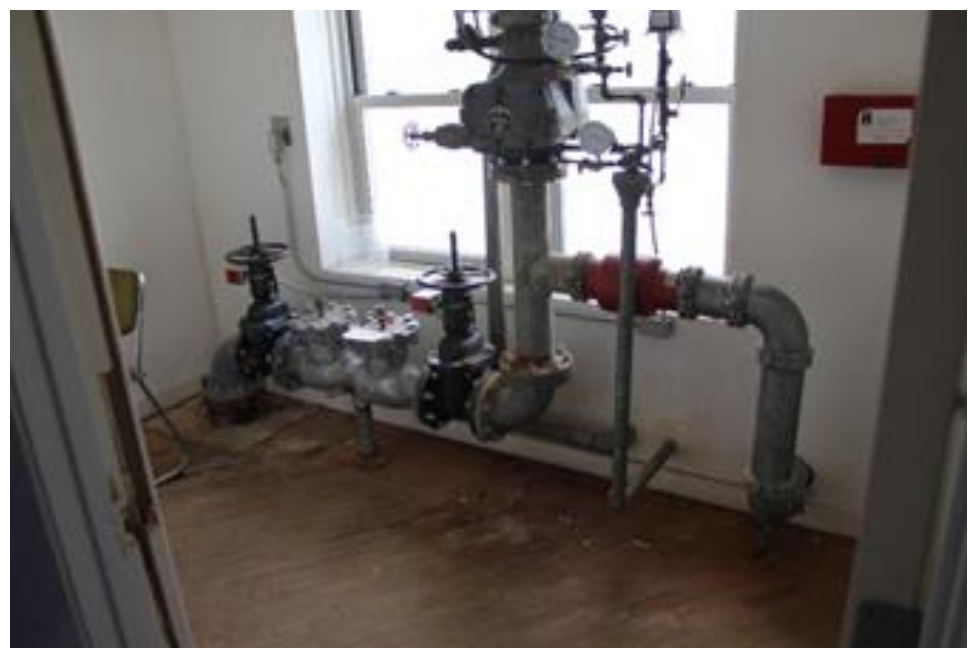




\section{A.11 Conclusions}

Bldgs. 2310 and 2311 have great potential for deconstruction. The major materials of interest in these buildings are the wooden structural members and the wall paneling, which should be reusable. The flooring of Bldg. 2311 should also be an easy material to reuse.

Special considerations include

- It may be difficult for large equipment to access areas adjacent to Bldgs. 2310 and 2311 since the east and west faces of the building are boxed in by railroad tracks and power lines. Consequently, hand deconstruction should be used as much as possible to mitigate any conflicts between surrounding structures/features and equipment.

- There are some signs of water damage to the roof and to some parts of the walls where small portions of the siding have pulled back.

- The flooring of Bldg. 2310 should be tested for asbestos before deconstruction takes place. 


\section{Appendix B: Detailed Assessment of Bldg. 2330}

Bldg. 2330 (Figure B-1) is a general-purpose warehouse in an active material distribution facility. It is of the same design as the rest of the buildings in the area, but the north half of the structure has already been removed. The brick firewall is still in place at one end of the building. The building is about $150 \mathrm{ft}$ long and $60 \mathrm{ft}$ wide; it has an interior floor area of $9,000 \mathrm{ft}^{2}$ and an exterior footprint of $9,200 \mathrm{ft}^{2}$. These are considered the common dimensions and configuration of the buildings in this report. The south end of the warehouse has small interior rooms.

Figure B-1. Bldg. 2330.

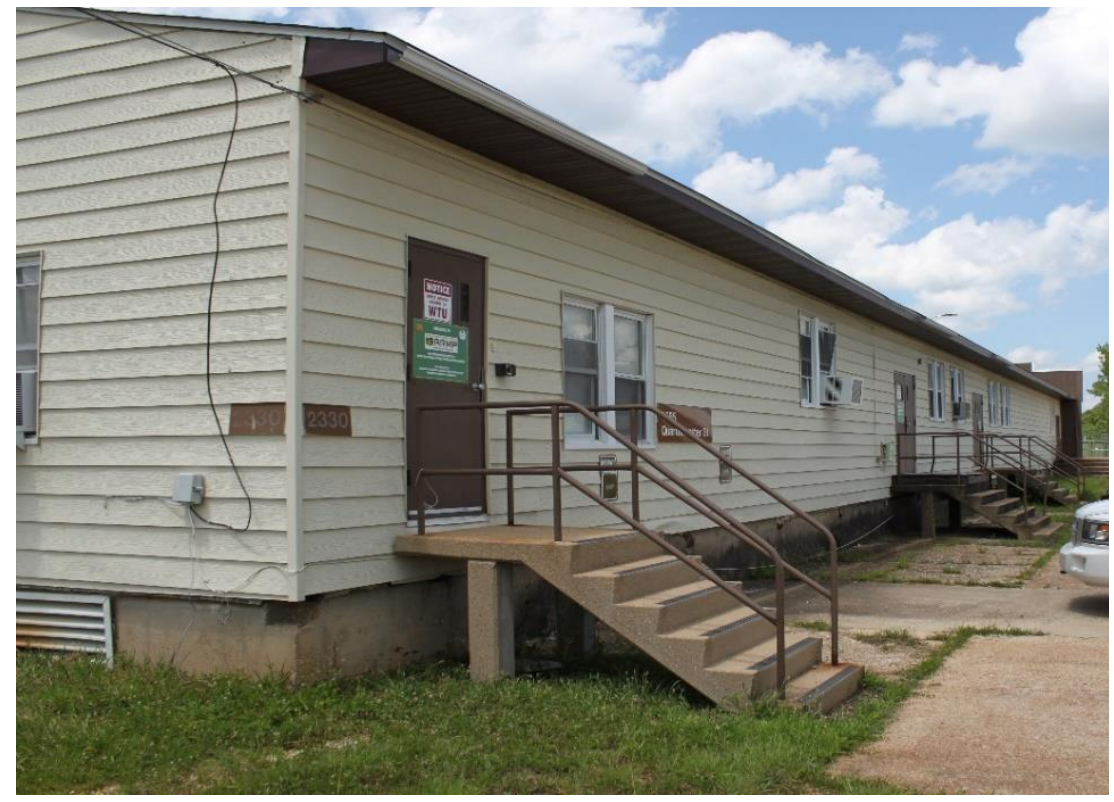

\section{B.1 Site}

Bldg. 2330 is close to and is easily accessed from the nearby roads. The surrounding area provides prime locations for equipment and material storage. The areas adjacent to the building afford little room for tall or large equipment since the east and west faces of the building are boxed in by railroad tracks and power lines. The area is generally level and should provide a fair amount of space for deconstruction. The concrete loading docks on the back side of the warehouse, which are in good repair (Figure B-2), are no longer in service. 
Figure B-2. Loading docks on the back side of the warehouse that are no longer in service.

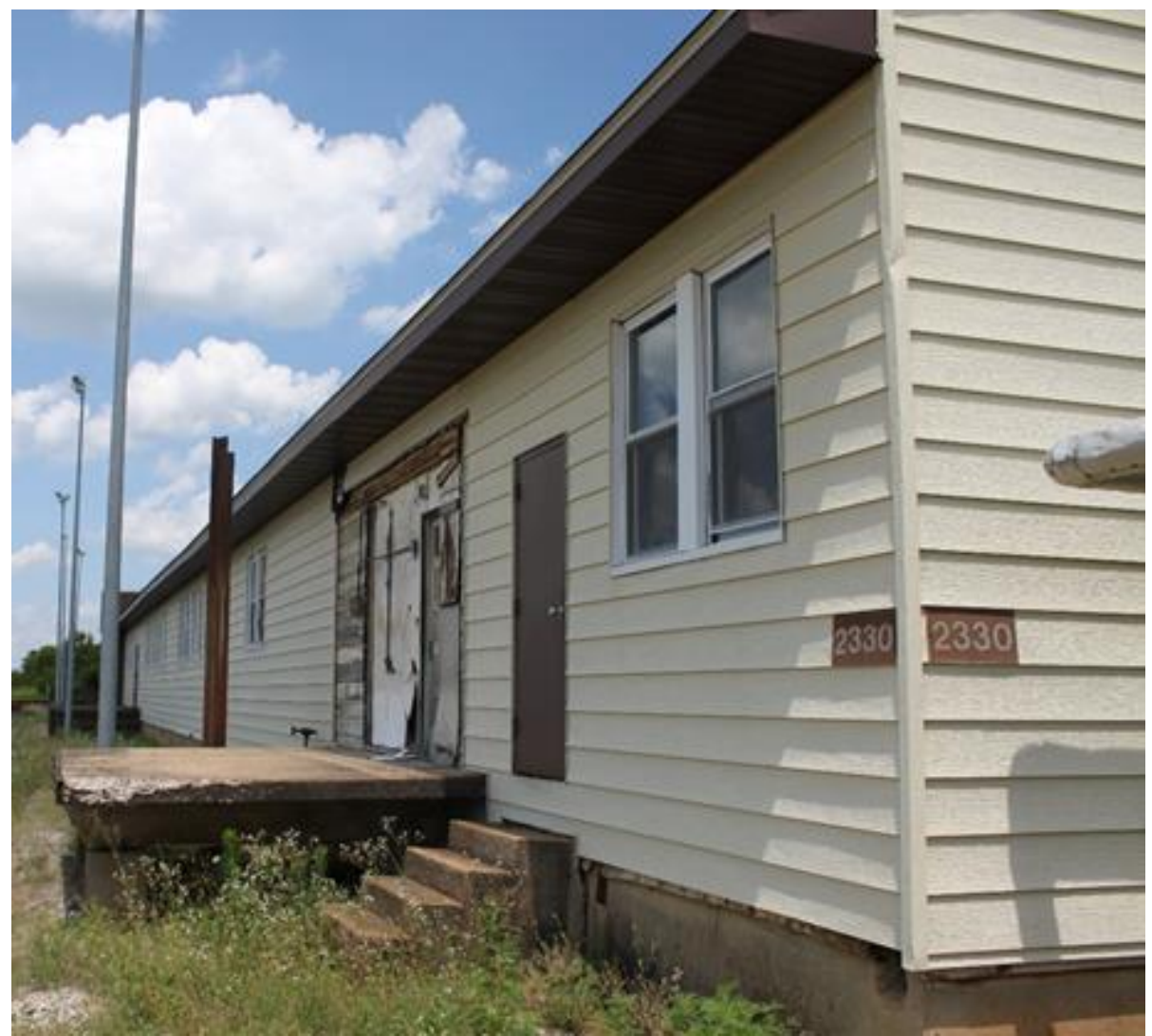

\section{B.2 Foundation}

The foundation is composed of five continuous footings running along the length of the facility and a continuous flooring at each end. The footings are $12 \mathrm{in}$. thick by $16 \mathrm{in}$. wide, and the walls of the flooring are $8 \mathrm{in}$. wide. The foundation walls are relatively tall to allow the finished floor elevations to reach railroad train car height. The footing depth is assumed to be at the frost depth (24 in. to 36 in.).

\section{B.3 Structure}

The floor system is supported by 2 in. $\times 12$ in. joists spaced at 12 in. on center spanning the foundation walls. The joists bear on 2 in. $\times 6$ in. sill plates and 2 in. $\times 12$ in. band joists that run the length of the building along the exterior walls. It is assumed that the condition of this subflooring is similar to that of Bldgs. 2338 and 2339. As no sign was posted in this building, it was assumed that the floor could support $150 \mathrm{lb} / \mathrm{ft}^{2}$.

Vertical loads are supported by 6 in. $\times 6$ in. columns on a $9 \mathrm{ft} \times 12 \mathrm{ft}$ grid. Columns are braced both laterally and longitudinally by 2 in. $\times 6$ in. 
braces. An estimated 150 braces range from $9 \mathrm{ft}$ to $16 \mathrm{ft}$ in length. Columns carry two $2 \times 12 \mathrm{~s}$ at each row along the length of the building. There are 60 columns throughout one-half of the building at heights of $16 \mathrm{ft}$ and $12 \mathrm{ft}$. Connections are nailed, not bolted.

The roof system is comprised of 2 in. $\times 8$ in. rafters spaced 24 in. on center, spanning the ridge to the exterior walls (Figure B-3). Roof decking is comprised of 8 in. wide boards installed perpendicular to the rafters (Figure B-4).

The total structural wood available for recovery is approximately 40,000 board $\mathrm{ft}$.

Figure B-3. Opening in roof system showing 2 in. $\times 8$ in. rafters.

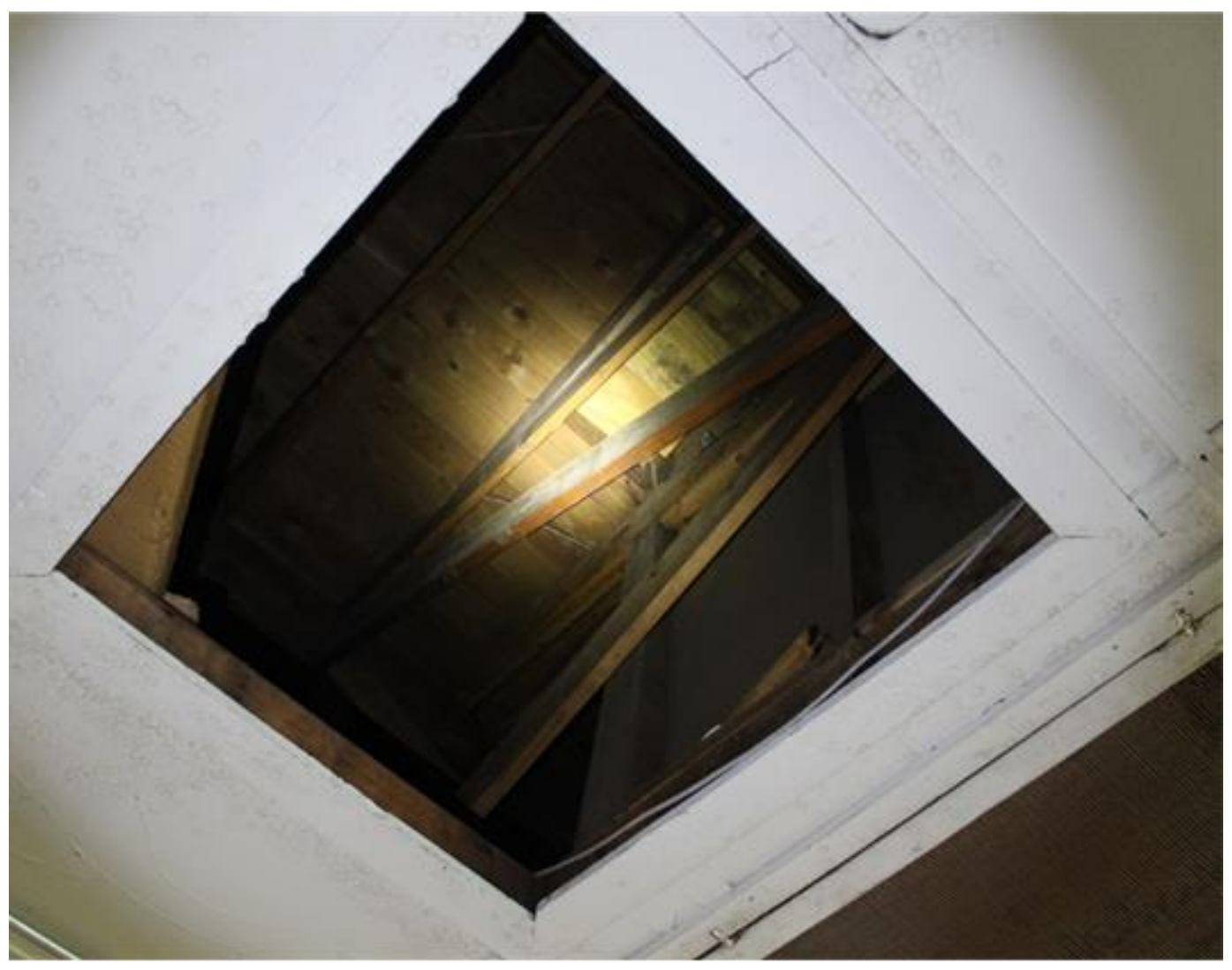


Figure B-4. Opening in roof system showing braced rafters.

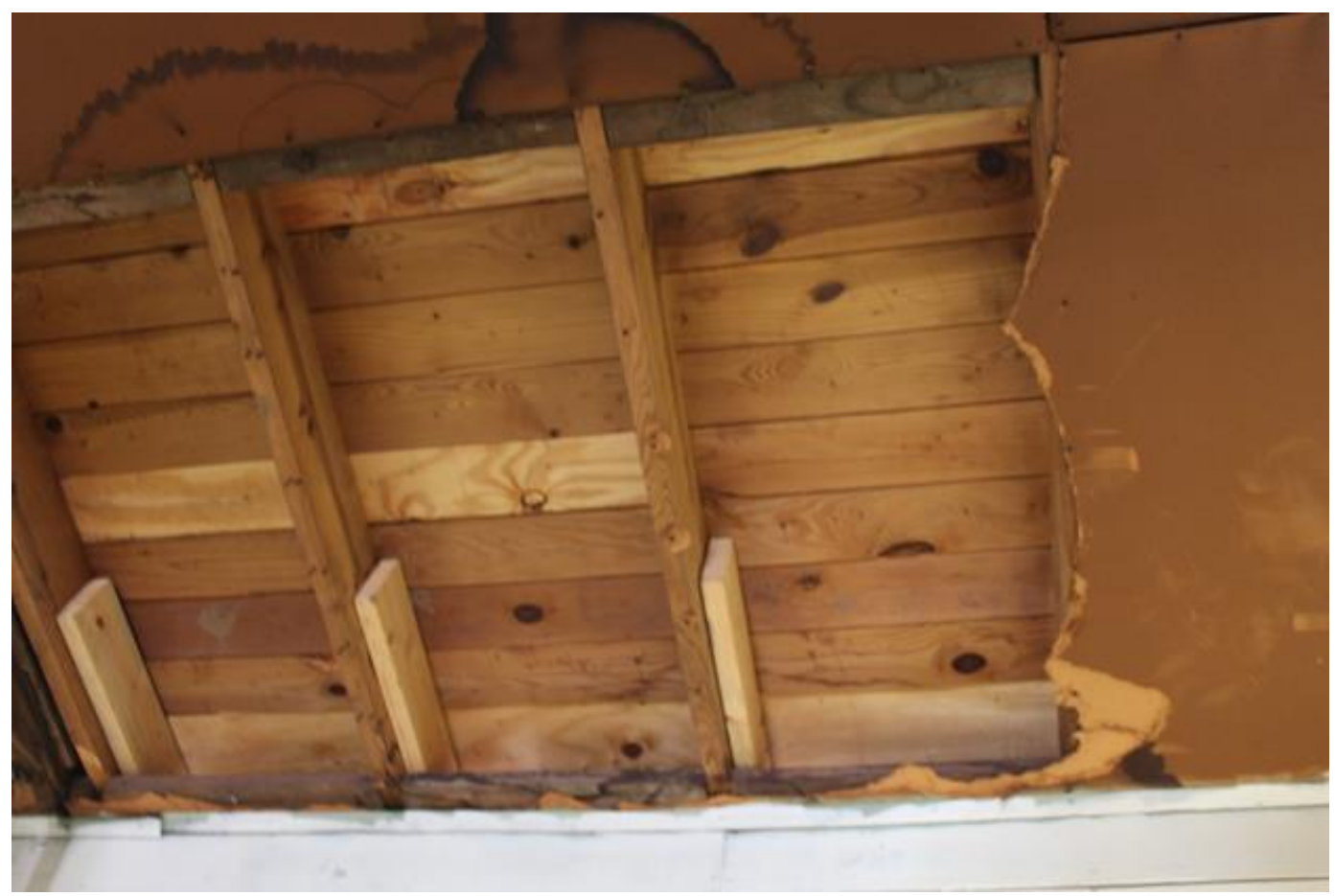

\section{B.4 Exterior enclosure}

The roof is a simple gable design with a 4:12 pitch. The roof wear surface is composed of asphalt three-tab shingles. The exterior walls are framed with 2 in. $\times 6$ in. studs, 24 in. on center, $9 \mathrm{ft} \mathrm{high}$. There are two top plates at both the top and bottom of the walls. A 2 in. $\times 6$ in. toe plate is installed at the bottom of the exterior walls. Horizontal boards are applied between the studs of the wall. The walls are sheathed with 6 in. boards applied diagonally.

The siding is thought to be steel, which depending on the condition, may be reusable; if not reusable, it can be recycled. The gutters and the underside of the deck awning are aluminum and can be recycled.

The roof shows signs of water leaks, and many sections have been patched or replaced. Based on this observation, it is assumed that some of the roof decking may not be in reusable condition.

The eaves and rakes of the gable ends are finished with aluminum soffit and fascia, which are recyclable. This, along with approximately $1,100 \mathrm{ft}^{2}$ of soffit and fascia and $300 \mathrm{ft}^{2}$ of aluminum material covering the fire walls, will yield approximately $700 \mathrm{lb}$ of recyclable aluminum. 
Bldg. 2330 has 3430 in. $\times 54$ in. exterior windows. These aluminum double-hung replacement-style windows would be suitable for reuse in nonconditioned spaces.

Bldg. 2330 has one 30 in. $\times 80$ in. exterior single door and three 60 in. $\times$ 80 in. double doors, all in good condition (Figure B-5). The loading doors have all been capped with plywood panels (Figure B-6).

Figure B-5. Exterior 60 in. $\times 80$ in. double doors.

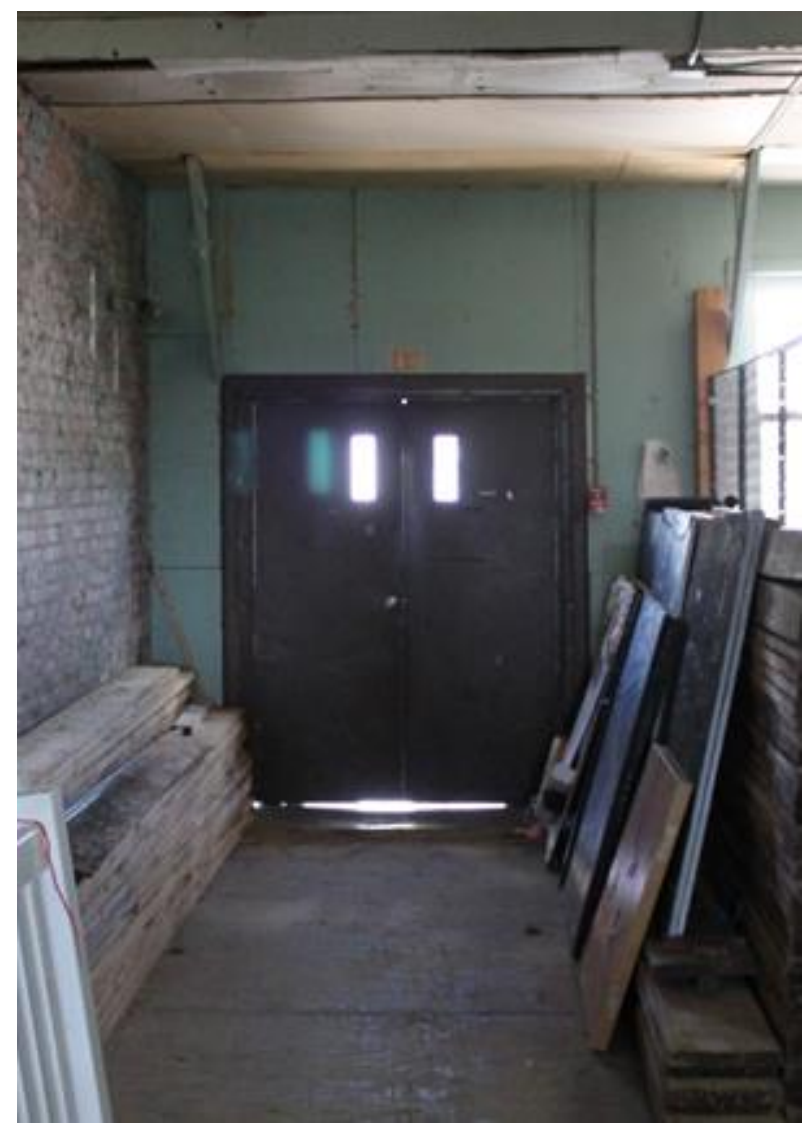


Figure B-6. Loading doors capped with plywood panels.

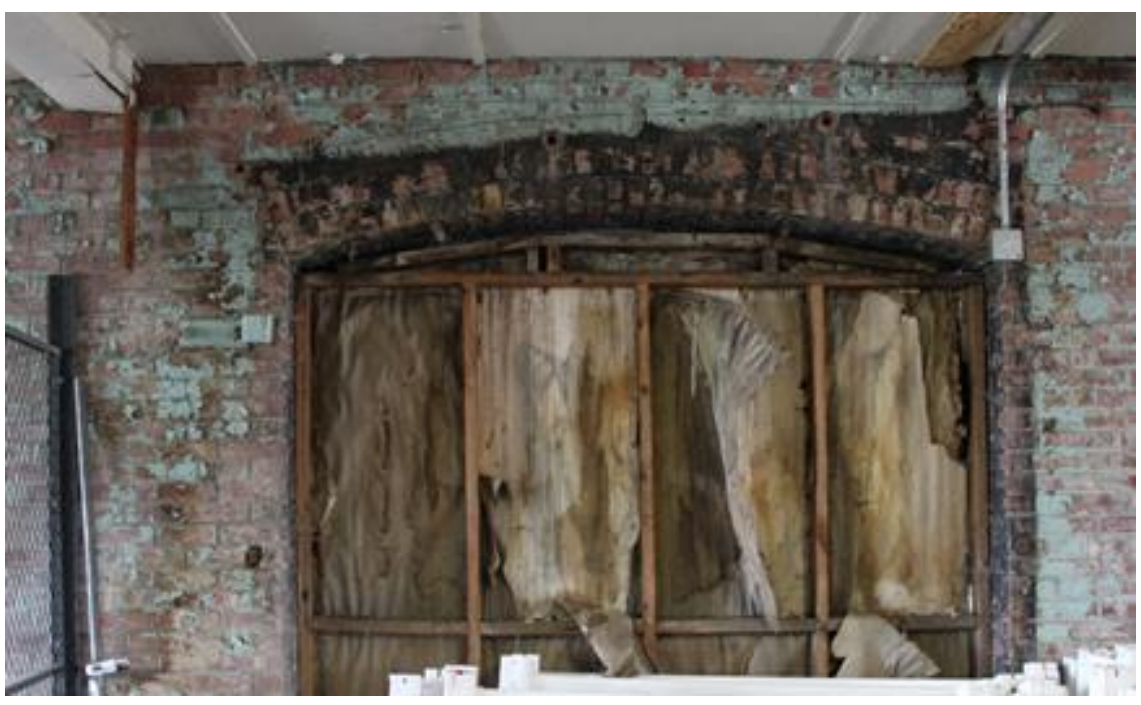

\section{B.5 Interior construction}

Bldg. 2330 has three lightweight, hollow-core, interior wooden doors that are not in reusable condition, and four solid pane glass interior windows.

The brick firewall used to separate the two halves of the warehouse still caps one end of the building. It is in fair condition with signs of water infiltration and mold growth. A large portion of the brick will not be reusable.

The flooring in Bldg. 2330 is covered with several layers of plywood and chipboard. The condition of the plywood is poor; it is heavily worn down with numerous signs of water damage (Figure B-7). Although the lower layers of the floor maybe reusable, a majority of the floor is not. 
Figure B-7. Heavily worn flooring in Bldg. 2330.

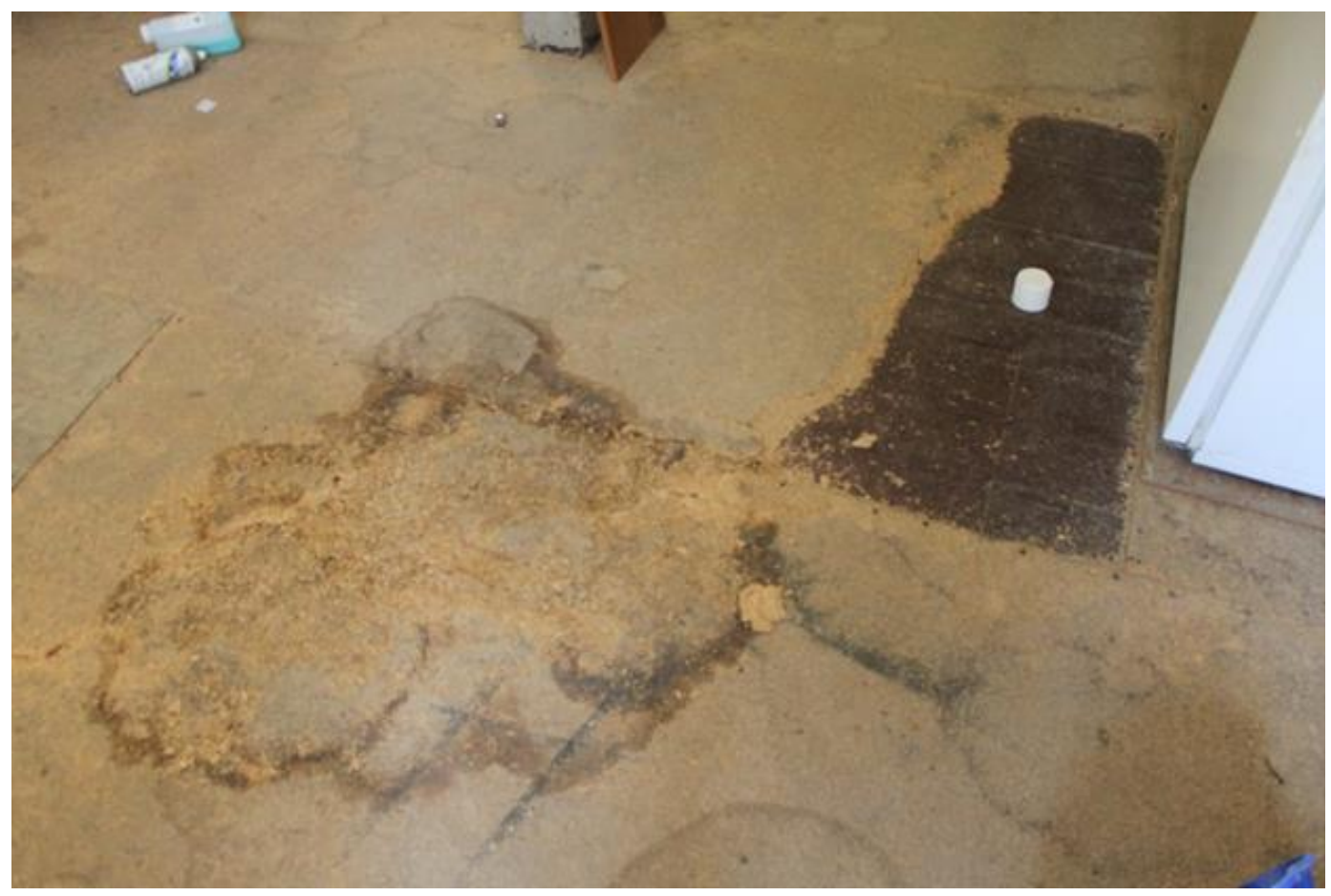

The walls in Bldg. 2330 are covered with about 5,000 ft ${ }^{2}$ of 6 in. wood paneling. The ceiling of the warehouse is thought to be plywood panels with thin strips to cover the seams. Most of the material is warped from water and time. It is unlikely that the ceiling panels can be reused, though the wall paneling may be reusable. The rest of the framing is estimated to consist of

- Rafters: 4,200 board ft,

- Walls (studs): 1,200 board ft,

- Trusses: 3,200 board ft,

- Support columns: 4,80o board ft, and

- Floor joists: 27,00o board ft.

\section{B.6 Plumbing}

Bldg. 2330 has one bathroom with a toilet and sink. The sink is in good condition and could be reused in another location. However, the toilet, which has an old-style flush valve, is unlikely to be reusable. An unknown amount of iron pipe feeds the bathroom. 


\section{B.7 Mechanical}

The mechanical room houses a Smith Cast Iron Boiler, model No. 28A-9, which services both Bldgs. 2330 and 2331 (Figure B-8). Bldg. 2331 is serviced with exterior, aboveground supply and return lines mounted on stands approximately $5 \mathrm{ft}$ above the ground. The interior of Bldg. 2330 is heated with at least seven overhead radiators located at ceiling height. There is approximately $600 \mathrm{ft}$ of heating system piping of indeterminate diameter.

Figure B-8. Smith Cast Iron Boiler, model No. 28A-9.

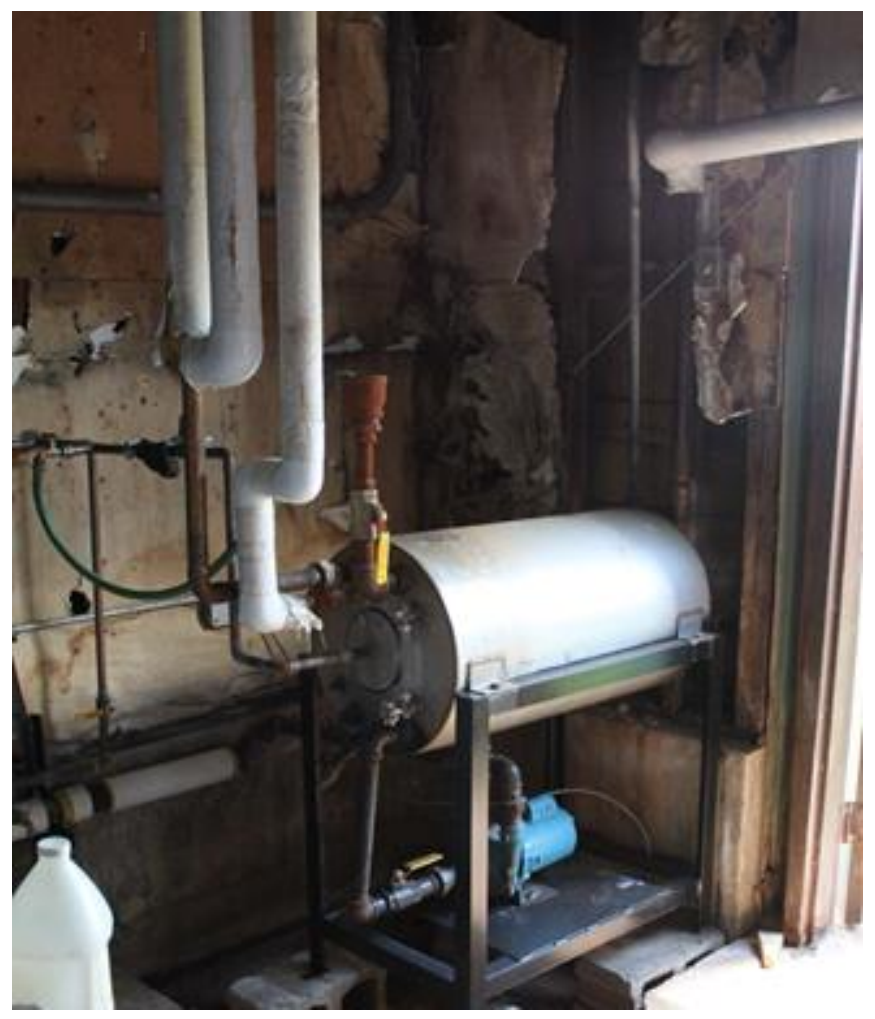

\section{B.8 Electrical}

Bldg. 2330 is lit by $4 \mathrm{ft}$, 2-tube industrial ceiling-hung fluorescent lights spaced along the length of the structure in both the storage and office areas. There are 95 such fixtures throughout the building in varying conditions. Most of the fixtures are serviceable and could be reused in similar environments.

A small amount of electrical conduit was found in Bldg. 2330. All electrical paneling and boxes are easily accessed and in fair condition, although they will need updated breakers for reuse. 


\section{B.9 Conclusions}

Bldg. 2330 has great potential for deconstruction. The major materials of interest are the wooden structural members and the wall paneling.

Special considerations include

- The floor shows some signs of water damage where small portions of the siding have pulled back.

- It may be difficult for large equipment to access areas adjacent to Bldg. 2330 since the east and west faces of the building are boxed in by railroad tracks and power lines. Consequently, hand deconstruction should be used as much as possible to mitigate any conflicts between surrounding structures/features and equipment.

- Though not pictured in the report, all chain link fences will be retained by the occupant.

- Note that the boiler in the mechanical room is connected to Bldg. 2331; the effect of its removal needs to be addressed before deconstruction can take place. 


\section{Appendix C: Detailed Assessment of Bldg. 2332}

\section{C.1 General}

Bldg. 2332 (Figure C-1) is a general-purpose warehouse in an active material distribution facility. It is of the same design as the rest of the buildings in the area, but the north half of the structure has already been removed. The brick firewall is still in place at one end of the building. The building is about $150 \mathrm{ft}$ long and $60 \mathrm{ft}$ wide; it has an interior floor area of $9,000 \mathrm{ft}^{2}$ and an exterior footprint of $9,200 \mathrm{ft}^{2}$. These are considered the common dimensions and configuration of the buildings in this report. The south end of the warehouse has small interior rooms. Note that Bldg. 2332 is connected by a brick firewall to Bldg. 2331, which is not part of the deconstruction project.

Figure C-1. Bldg. 2332.

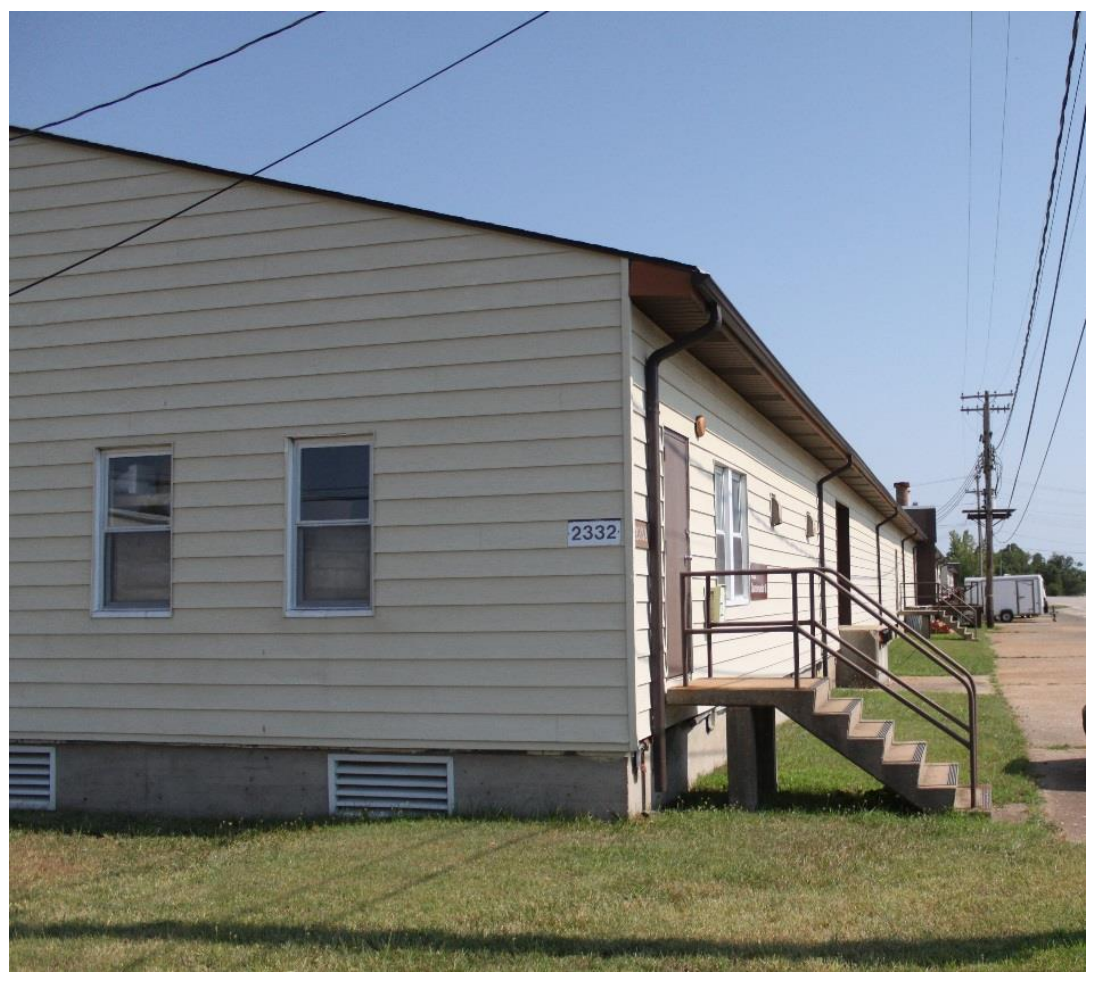

\section{C.2 Site}

Bldg. 2332 is close to and is easily accessed from the nearby roads. The surrounding area provides prime locations for equipment and material storage. The areas adjacent to the building afford little room for tall or 
large equipment since the east and west faces of the building are boxed in by railroad tracks and power lines. The area is generally level and should provide a fair amount of space for deconstruction. The concrete loading docks on the back side of the warehouse, which are in good repair (Figure $\mathrm{C}-2$ ), are no longer in service.

Figure C-2. Bldg. 2332, showing easy road access.

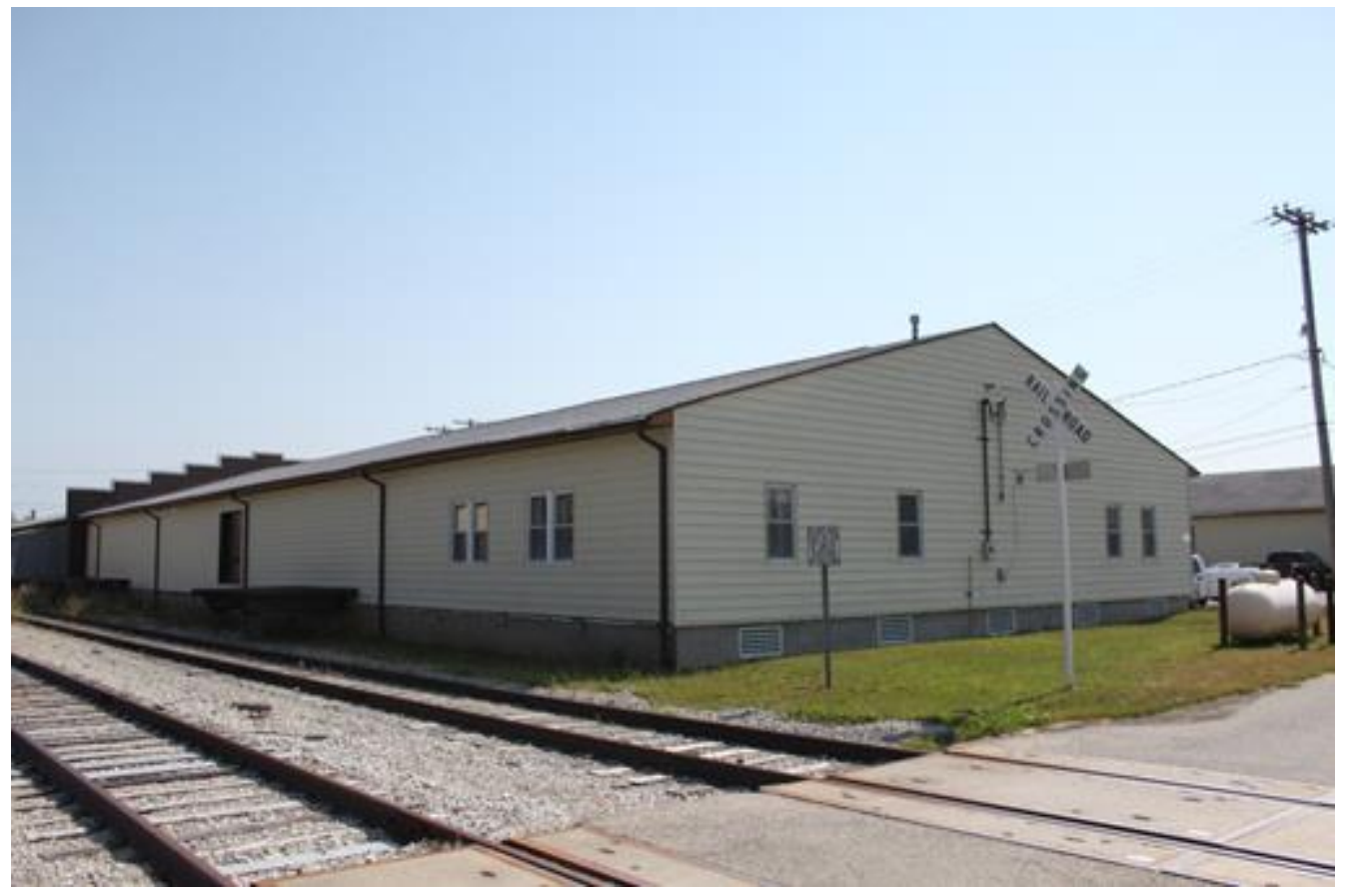

\section{C.3 Foundation}

The foundation is composed of five continuous footings running along the length of the facility and a continuous flooring at each end. The footings are 12 in. thick by $16 \mathrm{in}$. wide, and the walls of the flooring are $8 \mathrm{in}$. wide. The foundation walls are relatively tall to allow the finished floor elevations to reach railroad train car height. The footing depth is assumed to be at the frost depth (24 in. to 36 in.).

\section{C.4 Structure}

The floor system is supported by 2 in. $\times 12$ in. joists spaced at 12 in. on center spanning the foundation walls. The joists bear on 2 in. $\times 6$ in. sill plates and 2 in. $\times 12$ in. band joists that run the length of the building along the exterior walls. It is assumed that the condition of this subflooring is similar to that of Bldgs. 2338 and 2339. As no sign was posted in this building, it was assumed that the floor could support $150 \mathrm{lb} / \mathrm{ft}^{2}$. 
Vertical loads are supported by 6 in. $\times 6$ in. columns on a $9 \mathrm{ft} \times 12 \mathrm{ft}$ grid. Columns are braced both laterally and longitudinally by 2 in. $\times 6$ in. braces. An estimated 150 braces range from $9 \mathrm{ft}$ to $16 \mathrm{ft}$ in length. Columns carry two $2 \times 12 \mathrm{~s}$ at each row along the length of the building. There are 60 columns throughout one-half of the building at heights of $16 \mathrm{ft}$ and $12 \mathrm{ft}$. Connections are nailed, not bolted.

The roof system is comprised of 2 in. $\times 8$ in. rafters spaced 24 in. on center, spanning the ridge to the exterior walls (Figure C-3). Roof decking is comprised of 8 in. wide boards installed perpendicular to the rafters.

The total structural wood available for recovery is approximately 40,000 board ft.

Figure C-3. Bldg. 2332 roof system, rafters spanning the ridge to the exterior walls.

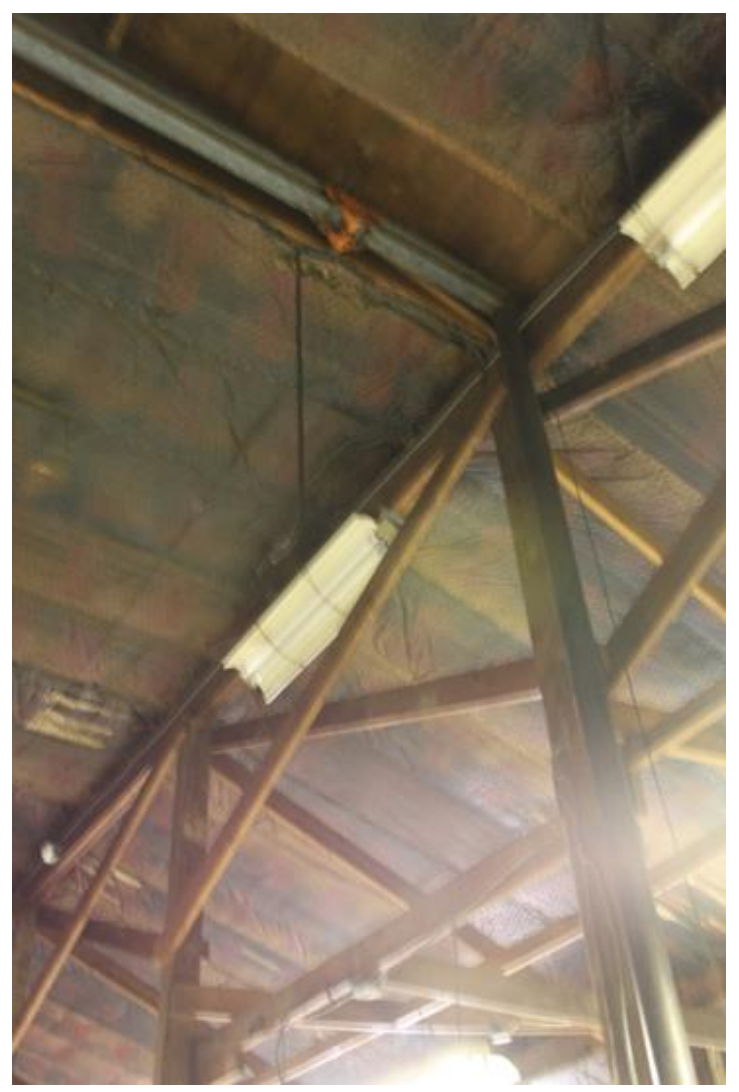




\section{C.5 Exterior enclosure}

The roof is a simple gable design with a 4:12 pitch. The roof wear surface is composed of asphalt three-tab shingles. Chicken wire appears to have been installed after initial construction to protect the insulation. The exterior walls are framed with 2 in. $\times 6$ in. studs, 24 in. on center, $9 \mathrm{ft} \mathrm{high}$. There are two top plates at both the top and bottom of the walls. A 2 in. $\times 6$ in. toe plate is installed at the bottom of the exterior walls. Horizontal boards are applied between the studs of the wall. The walls are sheathed with $6 \mathrm{in}$. boards applied diagonally.

The siding is thought to be steel, which depending on the condition, may be reusable; if not reusable, it can be recycled. The gutters and the underside of the deck awning are aluminum and can be recycled.

The roof shows signs of water leaks, and many sections have been patched or replaced. Based on this observation, it is assumed that some of the roof decking may not be in reusable condition.

The eaves and rakes of the gable ends are finished with aluminum soffit and fascia, which are recyclable. This, along with approximately $1,100 \mathrm{ft}^{2}$ of soffit and fascia and $300 \mathrm{ft}^{2}$ of aluminum material covering the fire walls, will yield approximately $700 \mathrm{lb}$ of recyclable aluminum.

Bldg. 2332 has 1030 in. $\times 54$ in. exterior windows. These aluminum, double-hung replacement-style windows would be suitable for reuse in nonconditioned spaces. Bldg. 2332 also has two $30 \mathrm{in} . \times 80$ in. single exterior doors and two overhead metal doors, all in good condition.

\section{C.6 Interior construction}

Bldg. 2332 has three lightweight, hollow-core, interior wooden doors that are not in reusable condition,

The brick firewall that separates the two halves of the warehouse has a large corrugated metal door. Since Bldg. 2331 will still remain after this project, the wall cannot be deconstructed.

The flooring in Bldg. 2332 is covered with several layers of plywood and linoleum. The top layers are in poor condition (Figure C-4). Underneath it is a tongue-and-groove wooden floor (Figure $\mathrm{C}-5$ ), which is different from 
the other warehouses' flooring; the flooring boards are wider and run horizontally relative to the building's dimensions. This tongue-and-groove lower layer of the floor seems reusable.

Figure C-4. Worn flooring in Bldg. 2332.

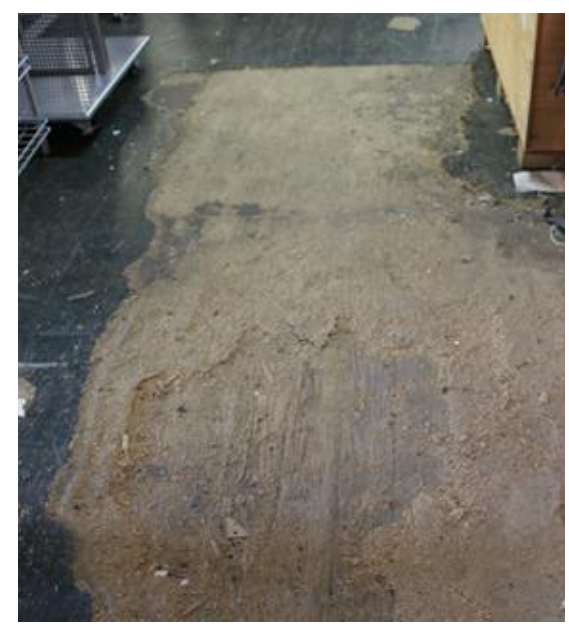

Figure C-5. Tongue-and-groove subfloor.

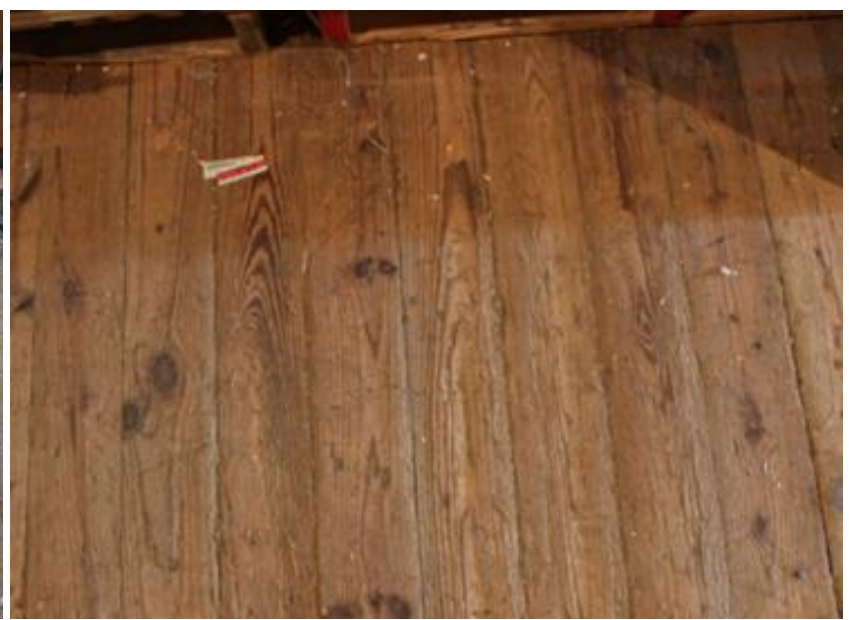

The walls in Bldg. 2332 are covered with about 1,000 ft² of 12 in. wood paneling. The ceiling of the office section appears to be composed of plywood panels with thin strips to cover the seams. It is unlikely that the ceiling panels can be reused, though the wall paneling may be reusable. The rest of the framing is estimated to consist of

- Rafters: 4,200 board ft,

- Walls (studs): 1,200 board ft,

- Trusses: 3,200 board ft,

- Support columns: 4,80o board ft, and

- Floor joists: 27,00o board ft.

\section{C.7 Plumbing}

Researchers could not access the rooms in Bldg. 2332 that may have plumbing since they were blocked off by storage. It is assumed that Bldg. 2332 either has no plumbing fixtures or that the fixtures would be similar to the fixtures assessed in the other warehouses in the area, which were generally unusable. 


\section{C.8 Mechanical}

Bldg. 2332 has no mechanical room, although there are two furnaces inside the storage section of the warehouse (Figure C-6). The larger of the two furnaces distributes heat through an estimated $130 \mathrm{ft}$ of ductwork.

Figure C-6. Furnace in warehouse storage section.

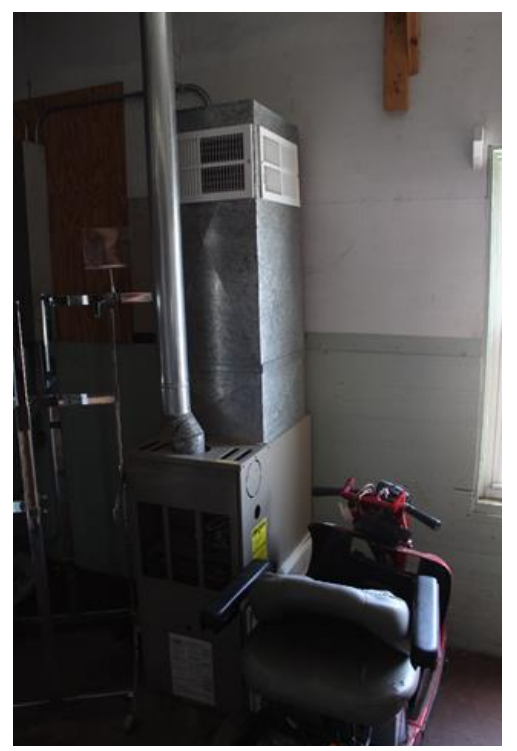

\section{C.9 Electrical}

Bldg. 2332 is lit by $4 \mathrm{ft}$, 2-tube industrial ceiling-hung fluorescent lights spaced along the length of the structure in both the storage and office areas. There are 50 such fixtures throughout the building in varying conditions. Most of the fixtures are serviceable and could be reused in similar environments.

There is a small amount of electrical conduit found in Bldg. 2332. All electrical paneling and boxes are easily accessed (Figure C-7) and in fair condition although they will need updated breakers for reuse. 
Figure C-7. Electrical box in Bldg. 2332.

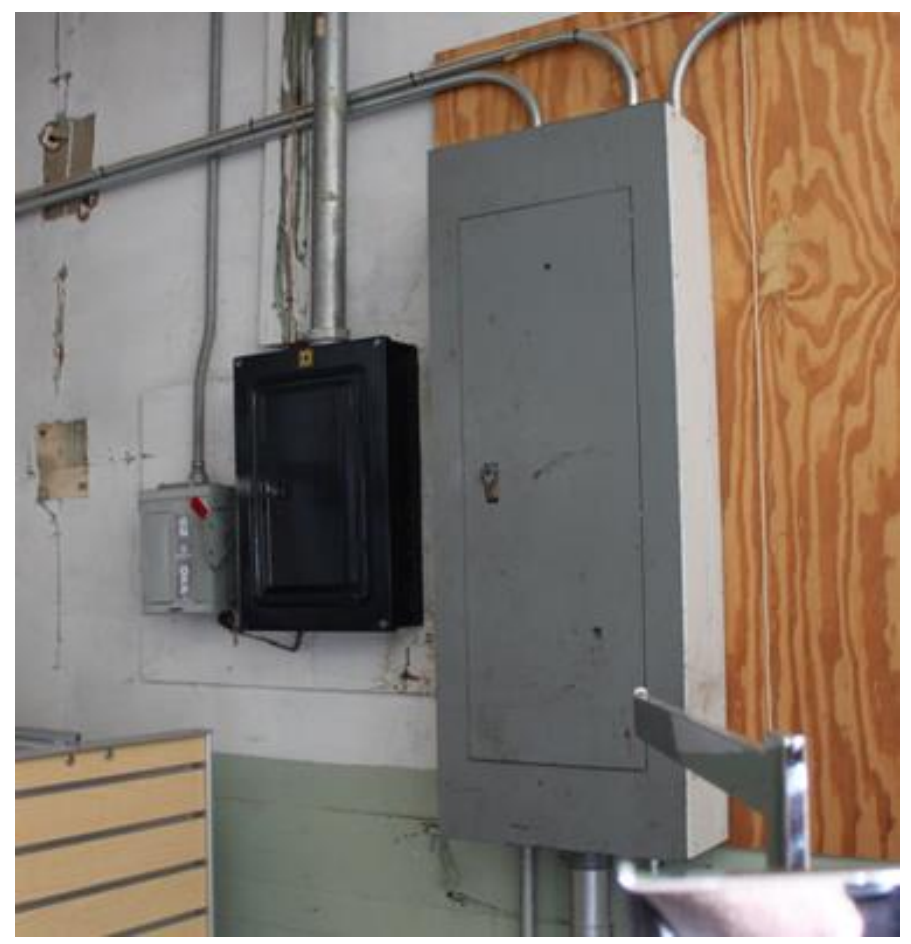

\section{C.10 Conclusions}

Bldg. 2332 has great potential for deconstruction. The major materials of interest are the wooden structural members and the wall paneling.

Special considerations include

- The floor shows some signs of water damage where small portions of the siding have pulled back.

- It may be difficult for large equipment to access areas adjacent to Bldg. 2330 since the east and west faces of the building are boxed in by railroad tracks and power lines. Consequently, hand deconstruction should be used as much as possible to mitigate any conflicts between surrounding structures/features and equipment.

- Note that the flooring of Bldg. 2332 should be tested for asbestos before deconstruction takes place. 


\section{Appendix D: Detailed Assessment of Bldgs. 2344-2345}

\section{D.1 General}

Bldgs. 2344 and 2345 (Figure D-1) are general-purpose warehouses in an active material distribution facility. The building is actually a single structure separated at the middle by a brick firewall, each half designated by its own building number. Each half the building is about $150 \mathrm{ft}$ long and $60 \mathrm{ft}$ wide; together they have an interior floor area of $9,000 \mathrm{ft}^{2}$ and an exterior footprint of $9,200 \mathrm{ft}^{2}$. These are considered the common dimensions and configuration of the buildings considered in this report. Both halves of the warehouse have small interior rooms.

Figure D-1. Bldgs. 2344 and 2345.

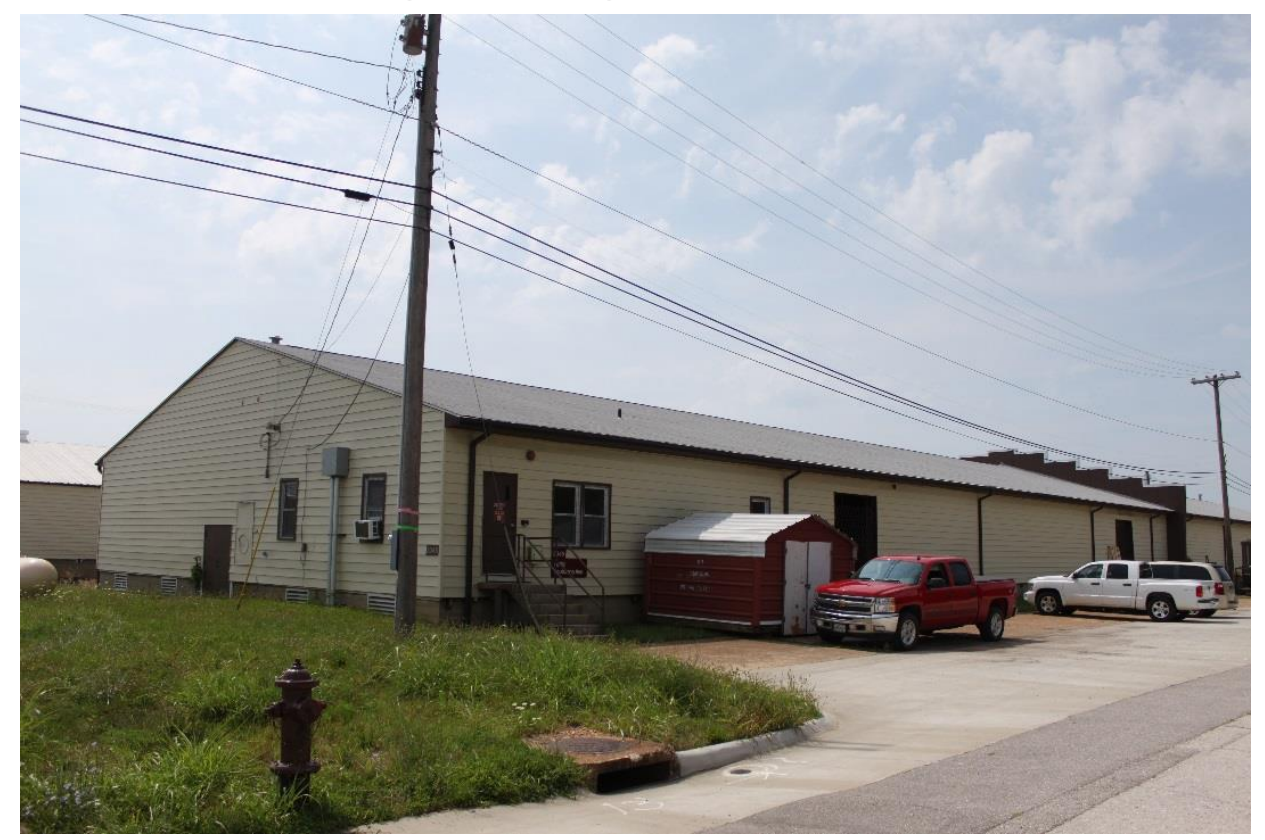

\section{D.2 Site}

The building is close to and is easily accessed from the nearby roads. The surrounding area provides prime locations for equipment and material storage. The areas adjacent to the building afford little room for tall or large equipment since the east and west faces of the building are boxed in by railroad tracks and power lines (Figure D-2). The area is generally level and should provide a fair amount of space for deconstruction. 
The concrete loading docks on the back side of the warehouse (Figure D-3), which are in good repair, are no longer in service. A $50 \mathrm{ft}$ long by $6.75 \mathrm{ft}$ wide wooden deck is on the front of the Bldg. 2344 side of the building; the loading dock extends all the way to the next building.

Figure D-2. Bldgs. 2344 and 2345 , showing proximity to railroad tracks.

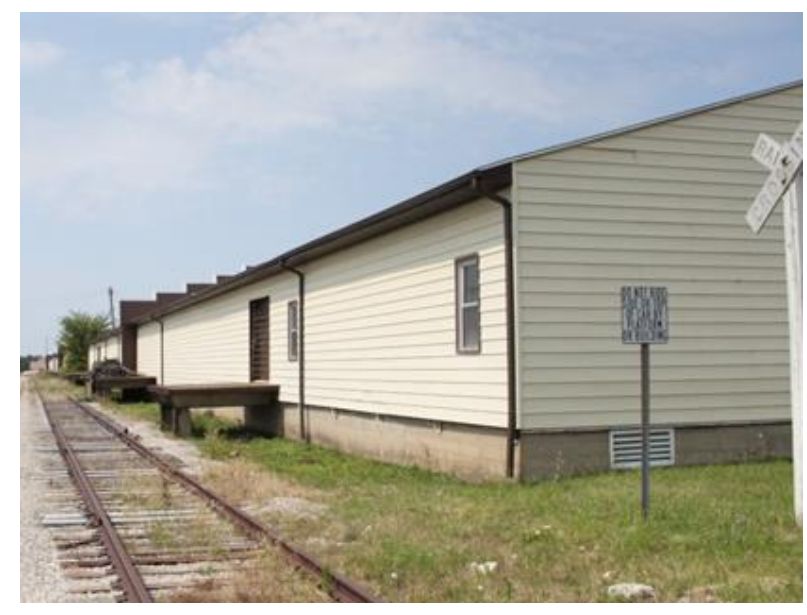

Figure D-3. Disused loading docks on the back side of the Bldgs. 2344 and 2345 (warehouse).

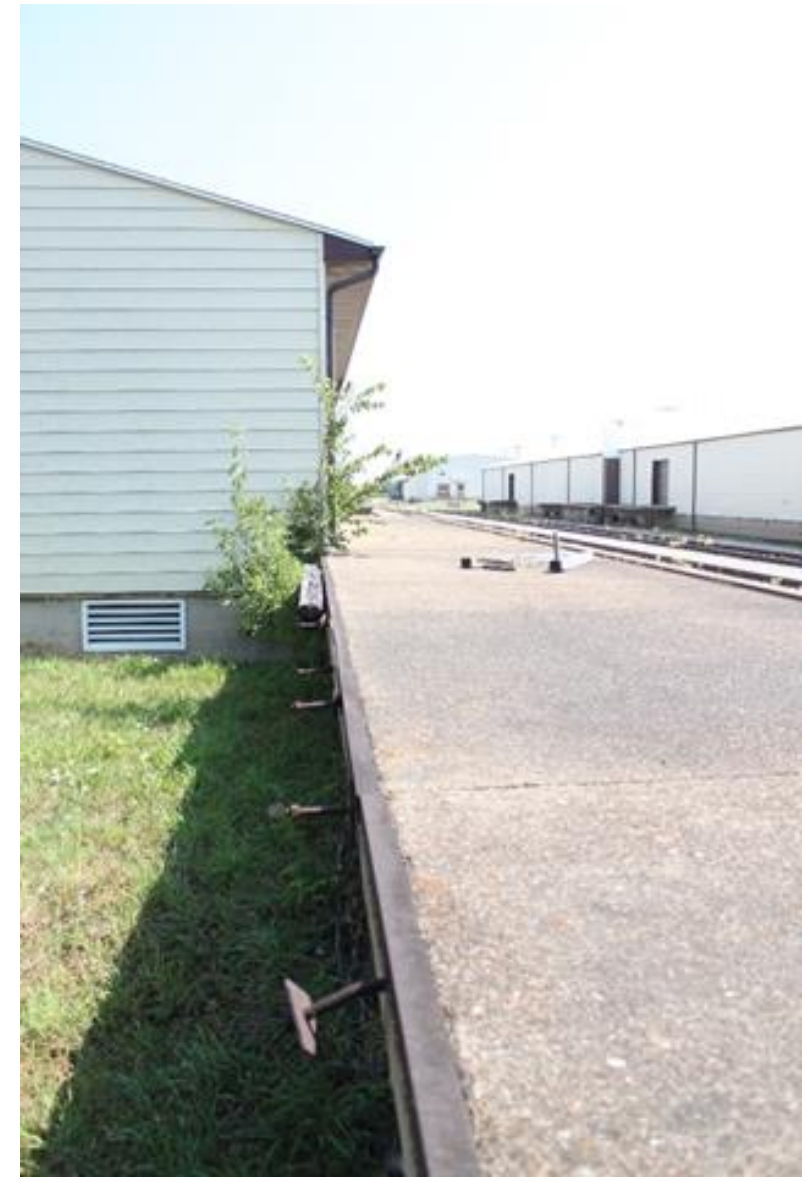




\section{D.3 Foundation}

The foundation has five continuous footings running along the length of the facility and a continuous flooring at each end. The footing is $12 \mathrm{in}$. thick by $16 \mathrm{in}$. wide, and the width of the walls of the flooring is $8 \mathrm{in}$. The foundation walls are relatively tall to allow for finished floor elevations at railroad train car elevation. The footing depth is assumed to be at the frost depth (24-36 in.).

\section{D.4 Structure}

The floor system is supported by 2 in. $\times 12$ in. joists spaced at 12 in. on center spanning the foundation walls. The joists bear on 2 in. $\times 6$ in. sill plates and 2 in. $\times 12$ in. band joists that run the length of the building along the exterior walls. It is assumed that the condition of this subflooring is similar to that of Bldgs. 2338 and 2339, and that the floor can support $192.5 \mathrm{lb} / \mathrm{ft}^{2}$.

Vertical loads are supported by 6 in. $\times 6$ in. columns on a $9 \mathrm{ft} \times 12 \mathrm{ft}$ grid. Columns are braced both laterally and longitudinally by 2 in. $\times 6$ in. braces. An estimated 150 braces range from $9 \mathrm{ft}$ to $16 \mathrm{ft}$ in length. Columns carry two $2 \times 12 \mathrm{~s}$ at each row along the length of the building. There are 60 columns throughout one-half of the building at heights of $16 \mathrm{ft}$ and $12 \mathrm{ft}$. Connections are nailed, not bolted.

The roof system is comprised of 2 in. $\times 8$ in. rafters spaced 24 in. on center, spanning the ridge to the exterior walls (Figures D-4 and D-5). Roof decking is comprised of $8 \mathrm{in}$. wide boards installed perpendicular to the rafters.

The total structural wood available for recovery is approximately 40,000 board ft. 
Figure D-4. Bldgs. 2344 and 2345 wooden roofing system.

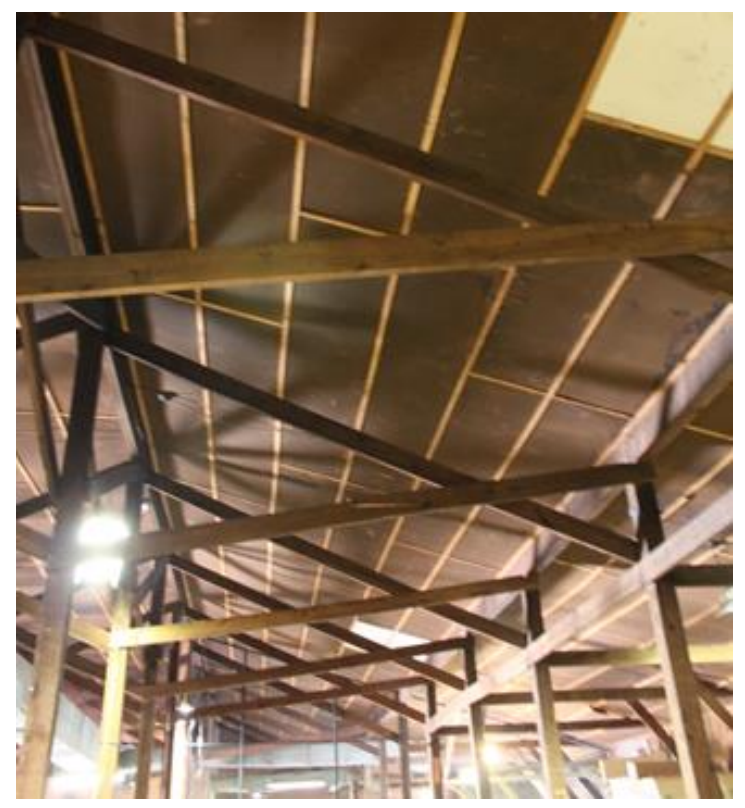

Figure D-5. Bldgs. 2344 and 2345 roofing system, lengthwise view.

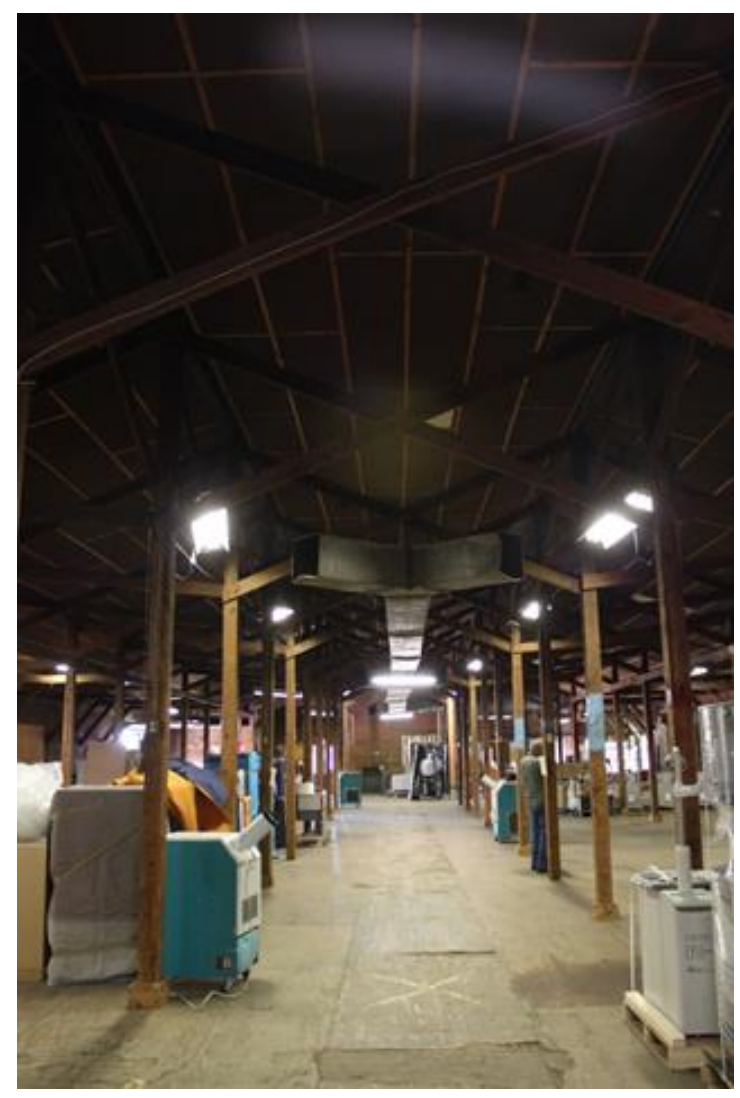




\section{D.5 Exterior enclosure}

The roof is a simple gable design with a 4:12 pitch. The roof wear surface is composed of asphalt three-tab shingles. The exterior walls are framed with 2 in. $\times 6$ in. studs, 24 in. on center, $9 \mathrm{ft}$ high. There are two top plates at both the top and bottom of the walls. A 2 in. $\times 6$ in. toe plate is installed at the bottom of the exterior walls. Horizontal boards are applied between the studs of the wall. The walls are sheathed with 6 in. boards applied diagonally.

The siding is thought to be steel, which depending on the condition, may be reusable; if not reusable, it can be recycled. The gutters and the underside of the deck awning are aluminum and can be recycled.

The roof shows signs of water leaks, and many sections have been patched or replaced. Based on this observation, it is assumed that some of the roof decking may not be in reusable condition.

The eaves and rakes of the gable ends are finished with aluminum soffit and fascia, which are recyclable. This, along with approximately $1,100 \mathrm{ft}^{2}$ of soffit and fascia and $300 \mathrm{ft}^{2}$ of aluminum material covering the fire walls, will yield approximately $700 \mathrm{lb}$ of recyclable aluminum.

Bldg. 2345 has seven exterior 30 in. $\times 54$ in. windows with steel wire cages on their faces. Bldg. 2344 also has six exterior windows of the same dimensions. These aluminum, double-hung replacement-style windows would be suitable for reuse in nonconditioned spaces.

Bldg. 2345 has three, $8 \mathrm{ft} \times 8 \mathrm{ft}$ overhead metal doors, all in serviceable, reusable condition (Figure D-6). Bldg. 2345 also has one exterior 30 in. $\times$ 80 in. single door, also in good condition. Bldg. 2344 has two overhead doors and one exterior single door, both in good condition. 
Figure D-6. Overhead metal door in Bldg. 2345.

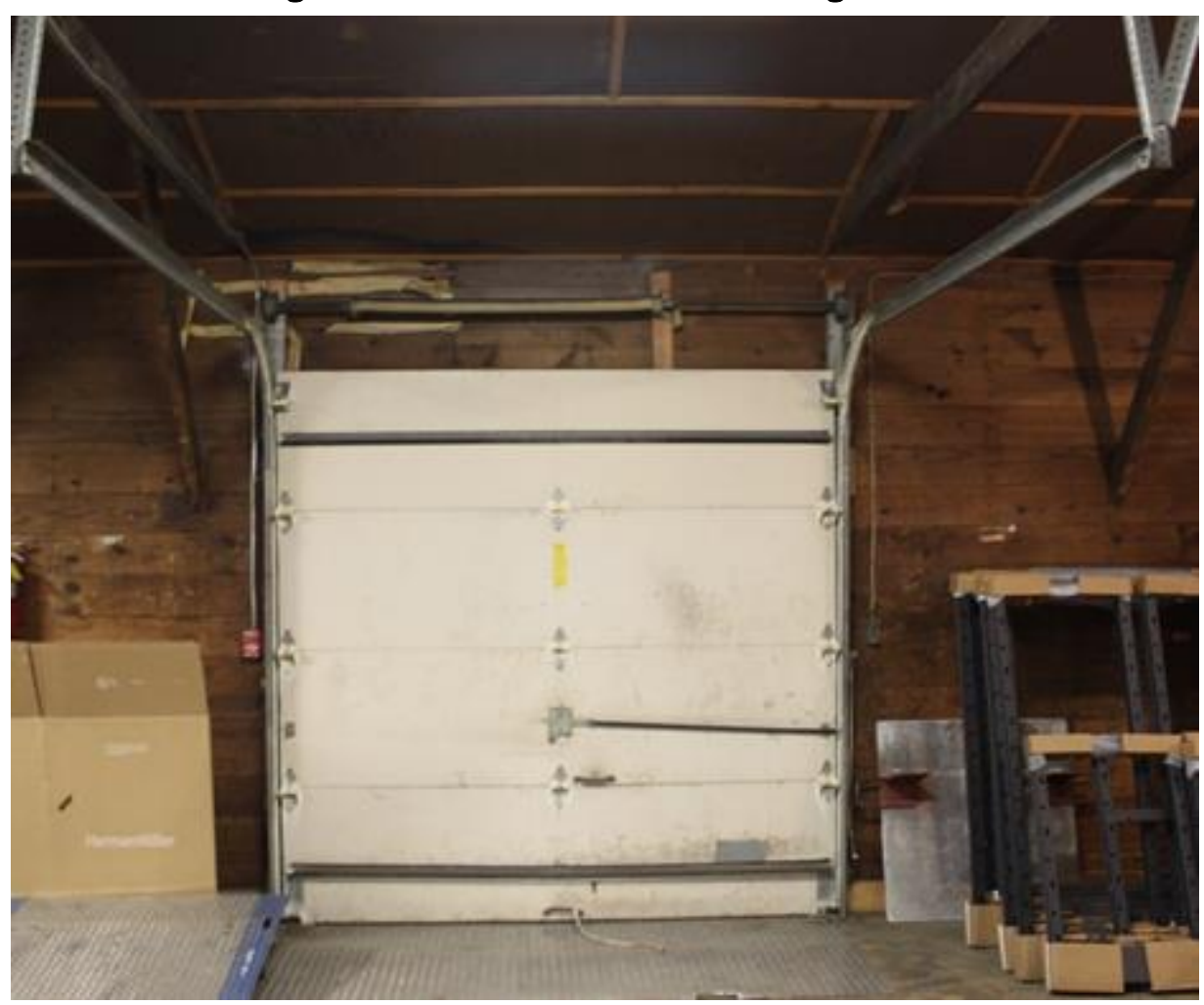

\section{D.6 Interior construction}

Bldgs. 2345 and 2344 each have three lightweight, hollow-core interior wooden doors that are not in reusable condition.

The two halves of the warehouse are separated by a brick firewall; two large corrugated metal doors on either side of the firewall (Figure D-7) allow passage through the center of the building. The doors are in good condition and have potential for reuse. 
Figure D-7. Large corrugated metal doors on either side of the fire wall in Bldg. 2345.

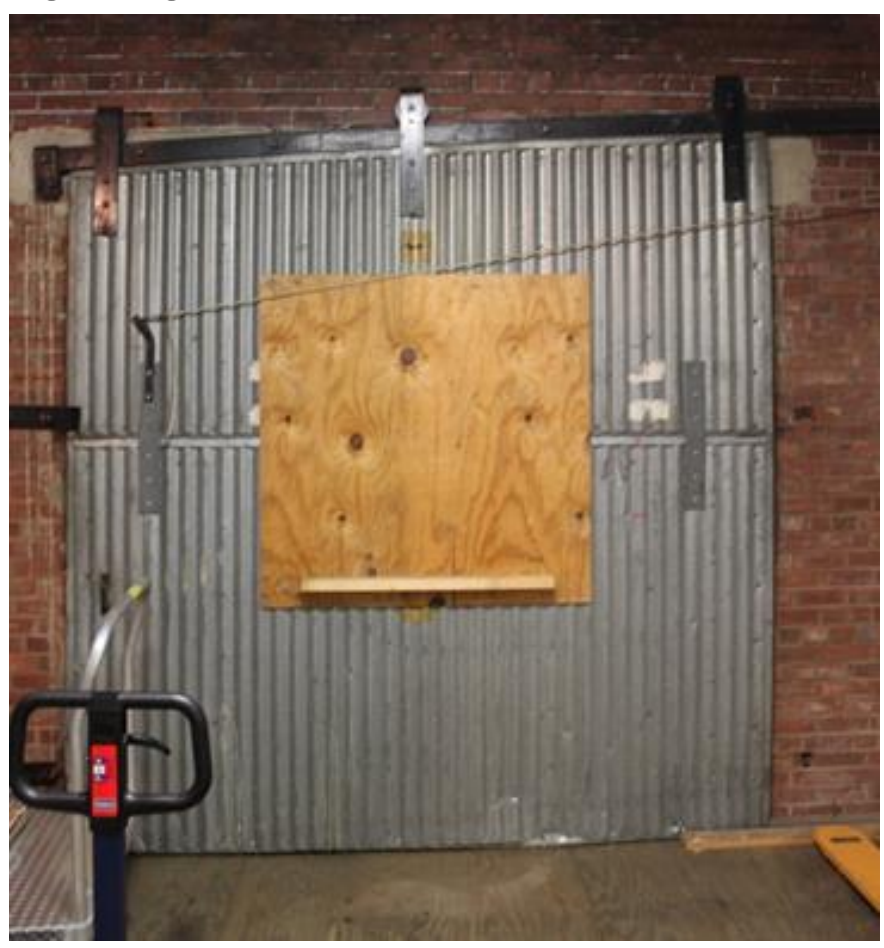

The flooring in the main storage area of Bldg. 2345 is covered with plywood; under the plywood there is evidence of the same diagonal maple floorboards found in other warehouses (Figure D-8). The condition of the plywood is moderate, but the maple boards should be well protected and in good shape. The floors in Bldg. 2344 are of the same materials, although the maple floorboard shows heavier wear patterns. That being said, much of the floor remains serviceable and can be reclaimed.

Figure D-8. Flooring in Bldg. 2345 showing diagonal maple boards.

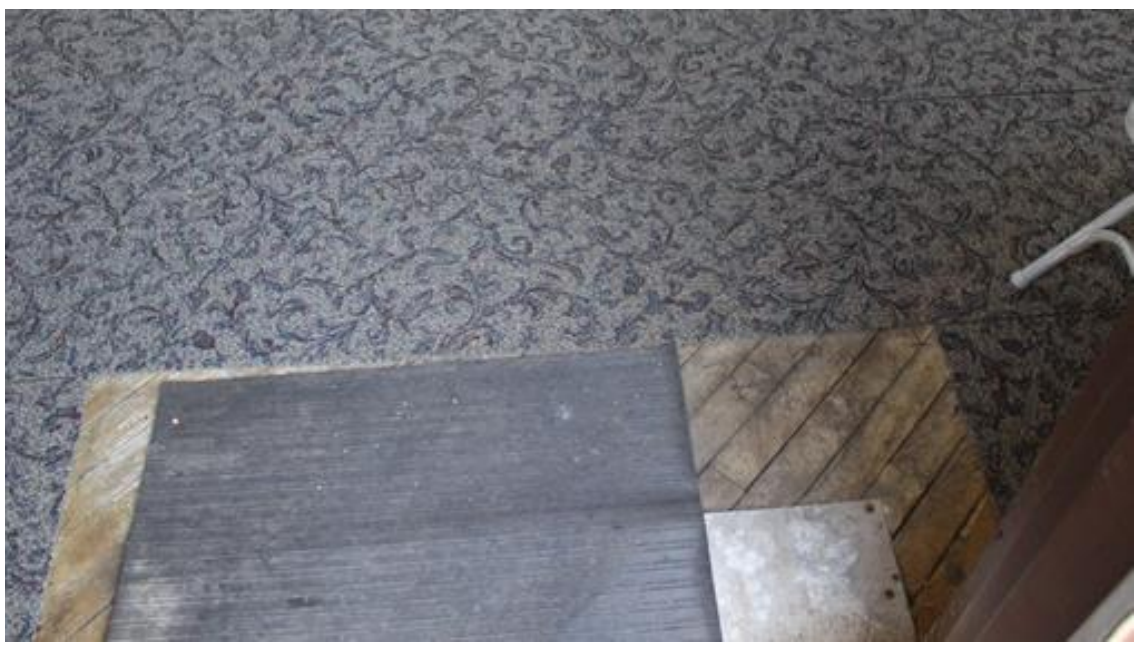


Chain link cages inside the storage area of Bldg. 2344 separate the different bays. Throughout the building, it is estimated that the cages are comprised of about $400 \mathrm{ft}$ of $10 \mathrm{ft}$ tall fencing topped with razor wire, and several swinging cage entry doors.

The walls in Bldg. 2345 are covered with about 4,300 ft² of 6 in. wood paneling (Figure D-9). The walls in Bldg. 2344 have a similar treatment, with an estimated 4,500 $\mathrm{ft}^{2}$ of paneling. The rest of the framing is estimated to consist of

- Rafters: 4,200 board ft,

- Walls (studs):1,200 board ft,

- Trusses: 3,200 board ft,

- Columns: 4,80o board ft, and

- Floor joists: 27,00o board ft.

Figure D-9. Wood wall paneling in Bldg. 2345.

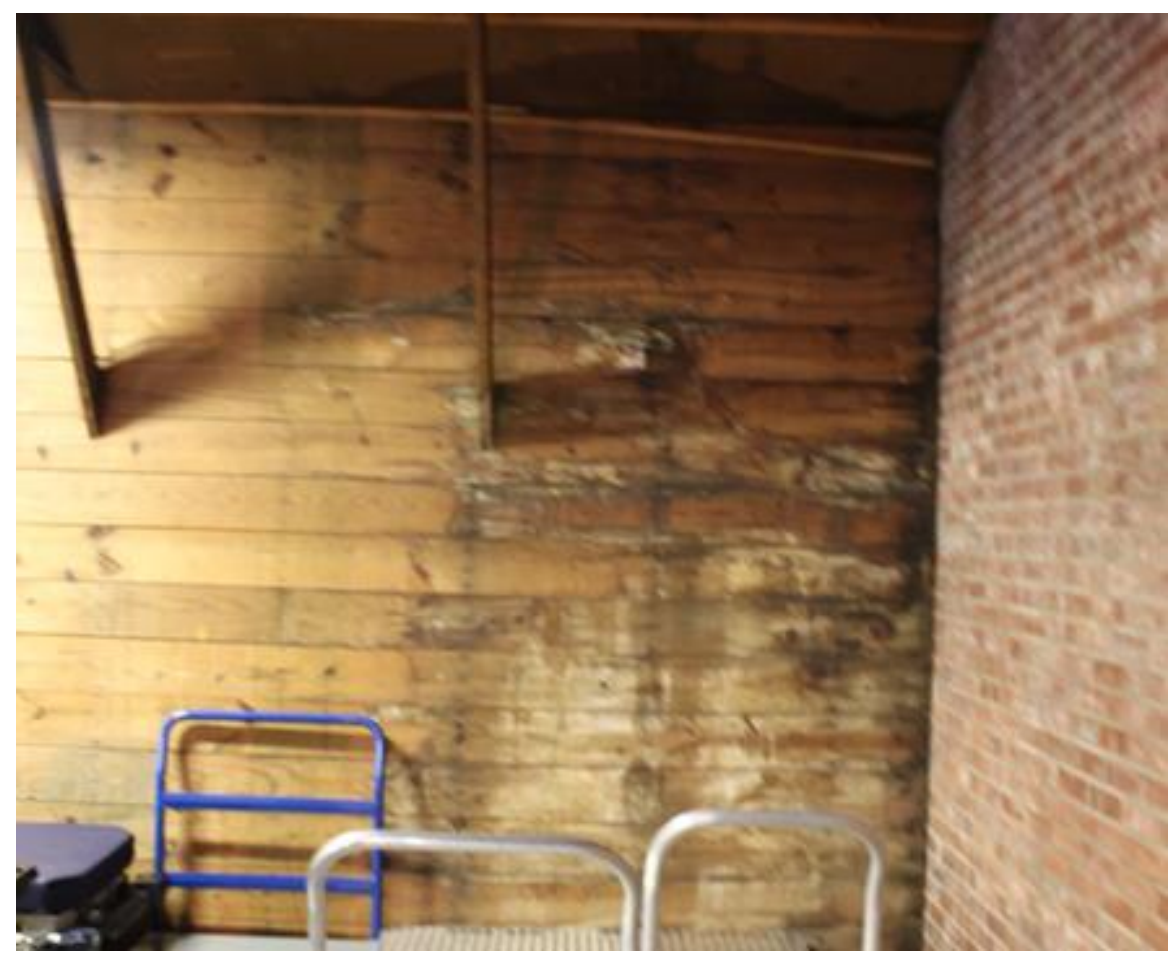

\section{D.7 Plumbing}

The Bldg. 2345 half of the building contains two bathrooms that, together, contain three toilets, two urinals, and two sinks. The toilets have old-style flush valves, and the sinks are damaged (Figures D-10 and D-11), so they are unlikely to be reusable. An unknown amount of iron pipe feeds both 
bathrooms. The bathroom in Bldg. 2344 has similar fixtures: a sink, urinal, and two toilets (see Figure D-12). These are in slightly better condition than those in Bldg. 2345, so they may be reusable, although it is unlikely. The office space has a double basin sink (Figure D-13) that is in good condition and could be reused.

Figure D-10. Typical sink in Bldg. 2345.

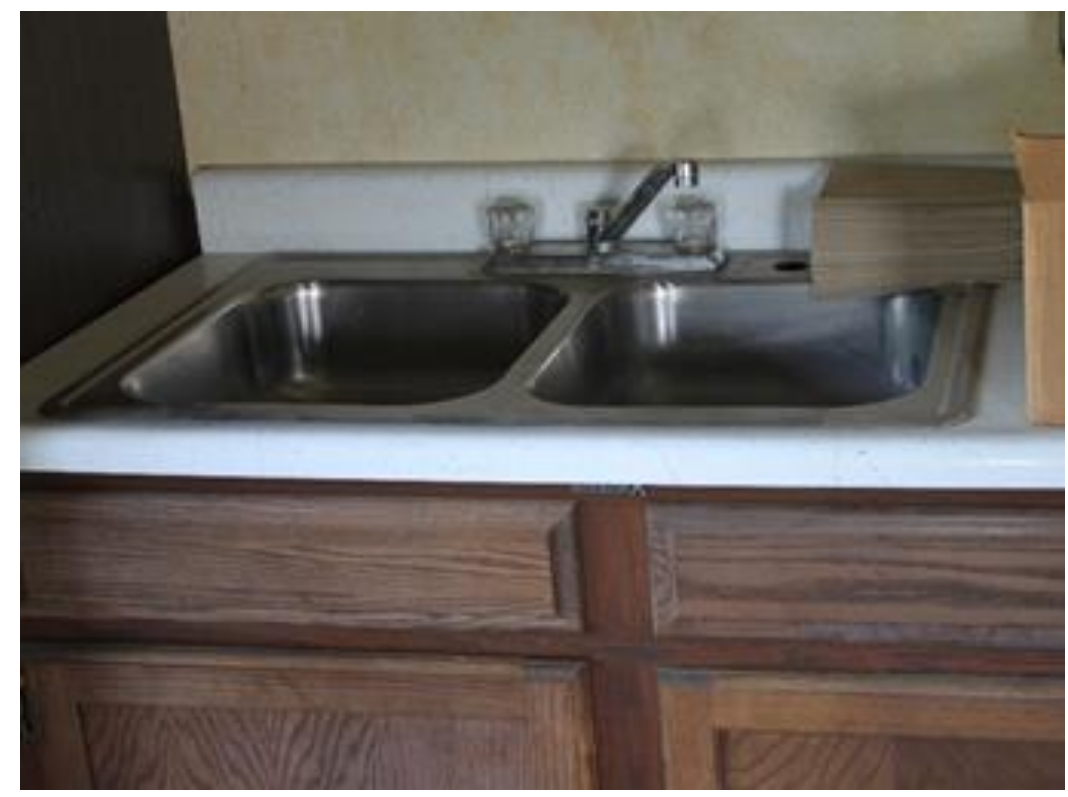

Figure D-11. Sink and urinal in Bldg. 2344.

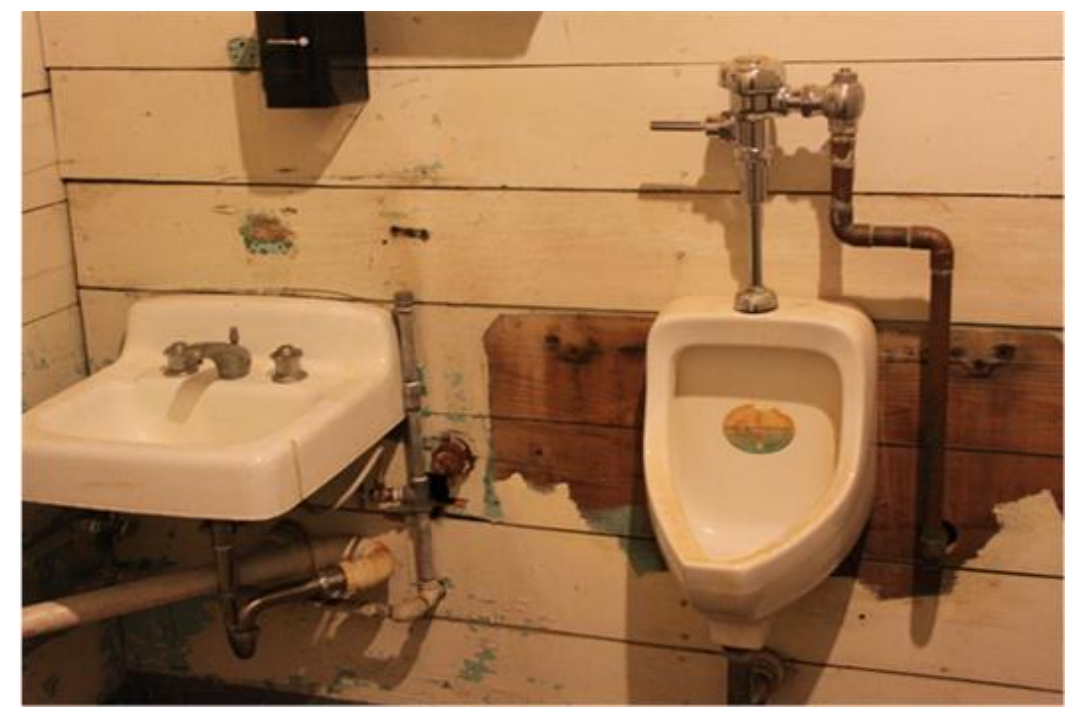


Figure D-12. Toilets in Bldg. 2345.

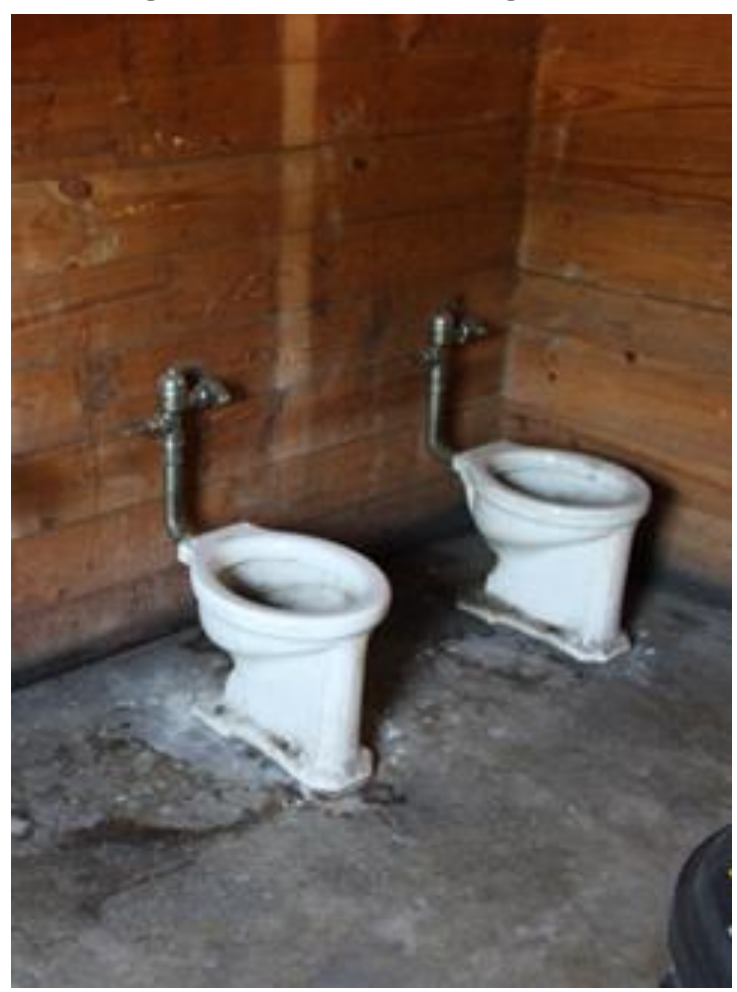

Figure D-13. Double basin sink

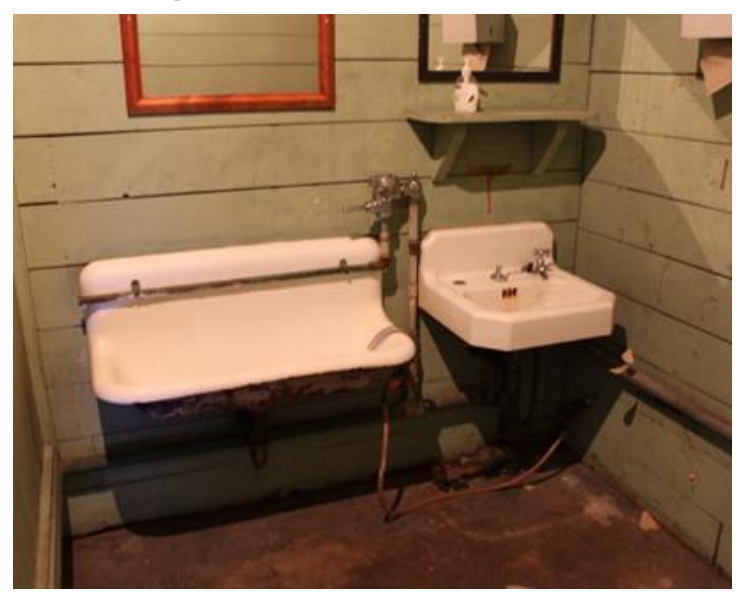

\section{D.8 Mechanical}

On the Bldg. 2345 side of the building, a mechanical room houses a Goodman furnace (Figure D-14). The furnace is in fair condition and could be reused in similar environments. The furnace serves the warehouse through an estimated $120 \mathrm{ft}$ of ductwork ranging from $2 \mathrm{ft}^{2}$ down to $18 \mathrm{in}^{2}$. The mechanical room in Bldg. 2344 houses a furnace with a similar amount of ductwork (Figure D-15) and a water heater that serves the sinks (Figure D-16). 
Figure D-14. Label on Goodman furnace. Figure D-15. Furnace in Bldg. 2344 mechanical room.

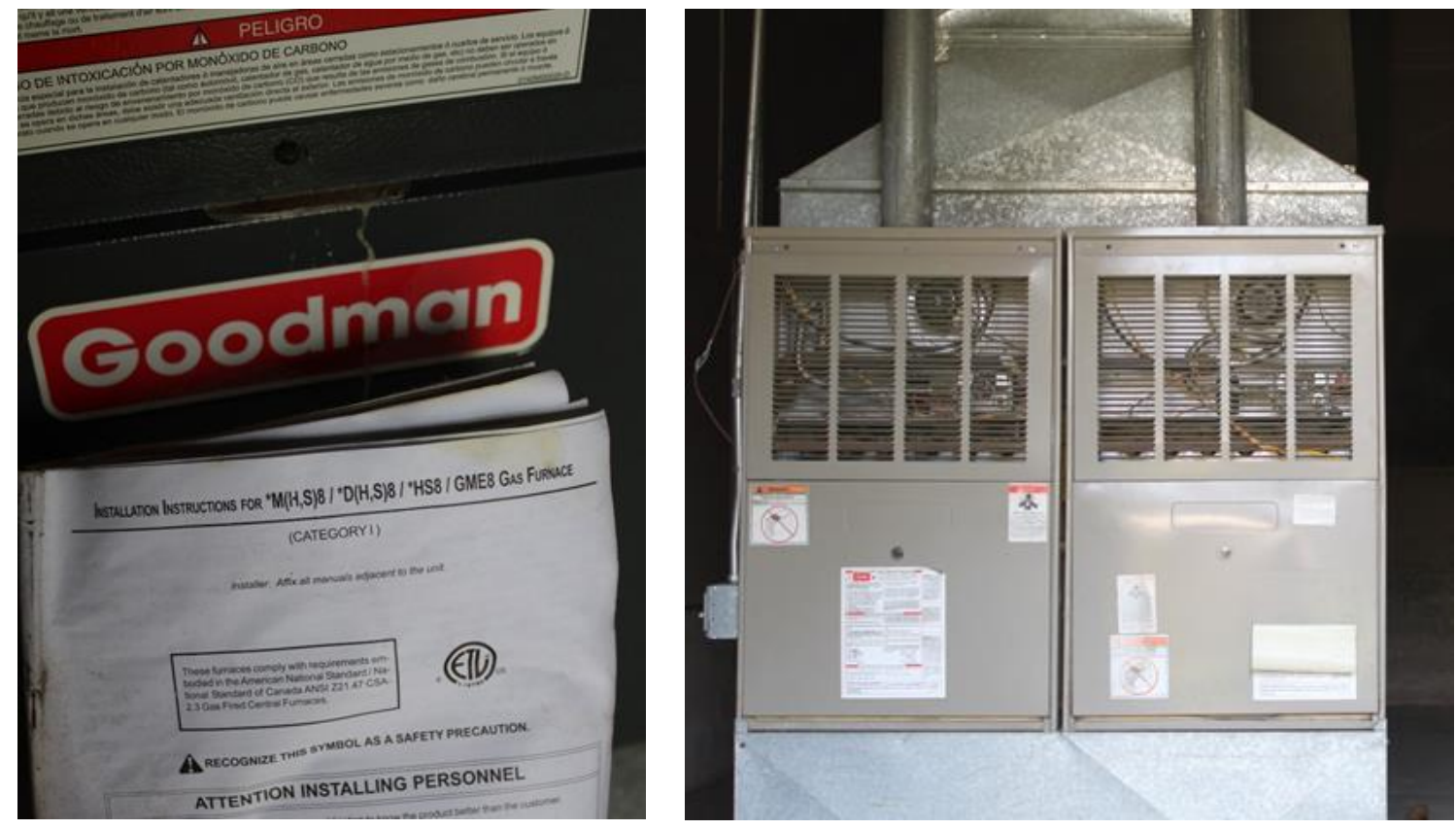

Figure D-16. Water heater for sinks in Bldg. 2344.

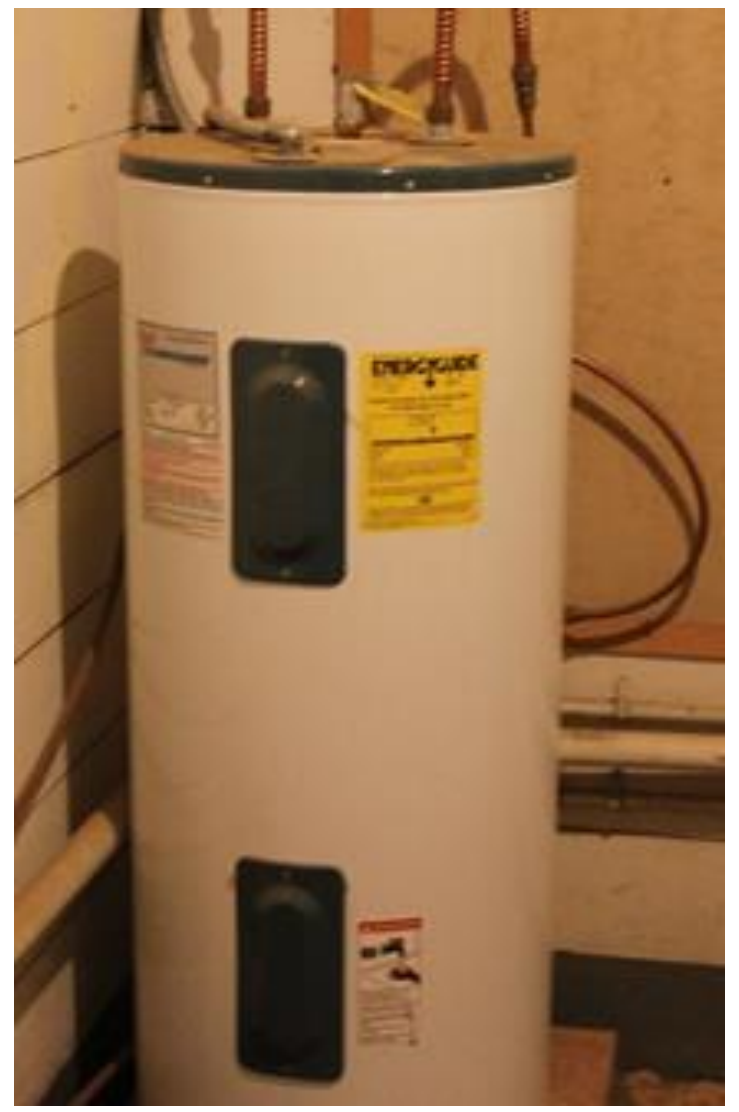




\section{D.9 Electrical}

The main storage areas in both buildings are lit by $4 \mathrm{ft}, 2$-tube industrial ceiling-hung fluorescent lights spaced along the length of the structure. There are 25 such fixtures in Bldg. 2345 and 20 in Bldg. 2344.

There is a small amount of electrical conduit found in Bldg. 2310. All electrical paneling and boxes are easily accessed and in fair condition, though they will need updated breakers for reuse (Figure D-17).

Figure D-17. Electrical paneling and boxes in Bldg. 2310.

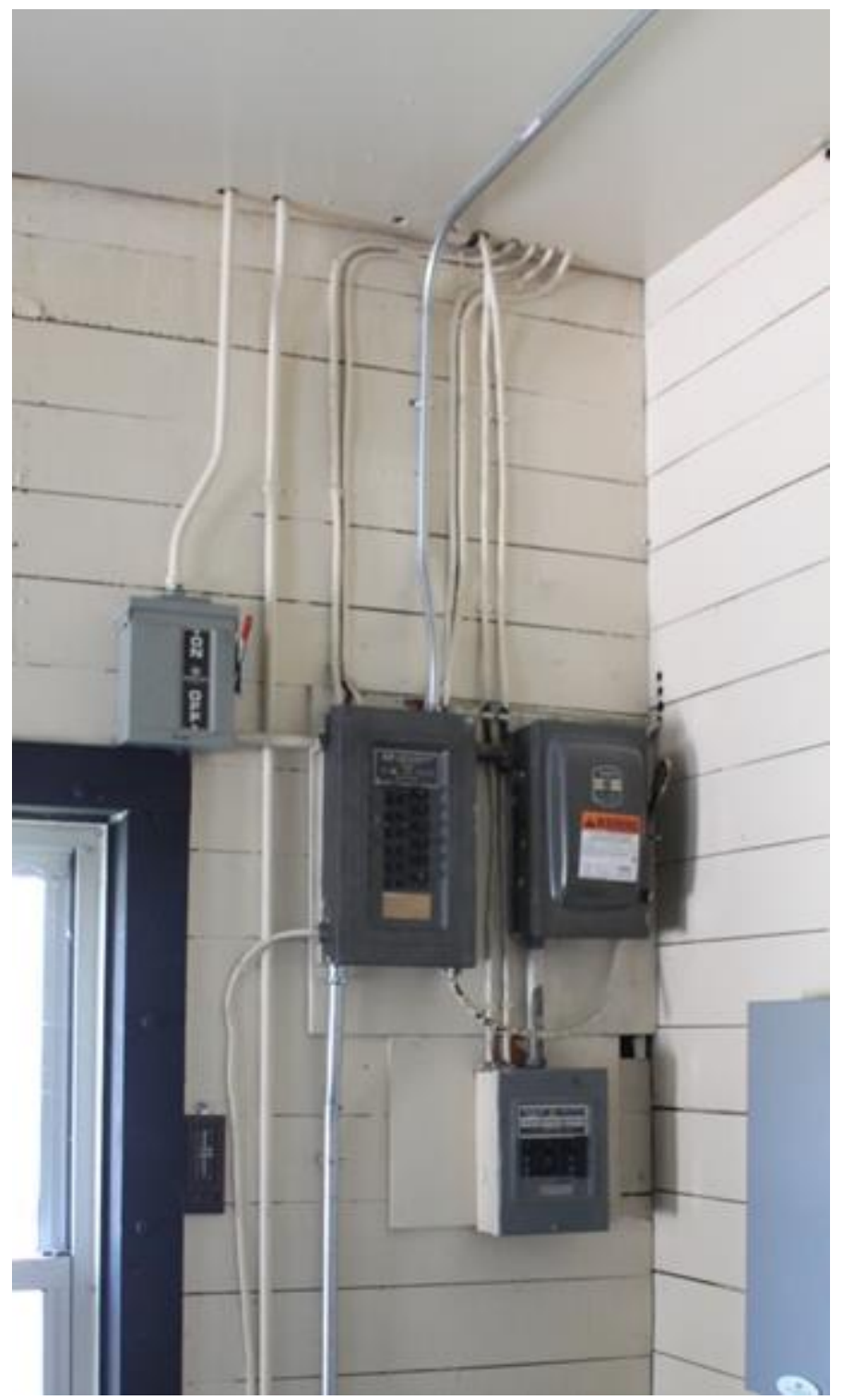




\section{D.10 Conclusions}

Bldgs. 2345-2344 have great potential for deconstruction. The major materials of interest are the wooden structural members and the wall paneling. The maple floorboards found under the plywood sections in both buildings should also be an easy material to reuse once the condition is confirmed.

Special considerations include

- It may be difficult for large equipment to access areas adjacent to Bldgs. 2345-2344 since the east and west faces of the building are boxed in by railroad tracks and power lines. Consequently, hand deconstruction should be used as much as possible to mitigate any conflicts between surrounding structures/features and equipment.

- There are some signs of water damage in the roof and in the wall paneling near the brick firewall.

- The walls of the mechanical rooms should be tested for asbestos before deconstruction takes place.

- Note that the large metal cage in the warehouse section of Bldg. 2345 will be retained by the occupants. 


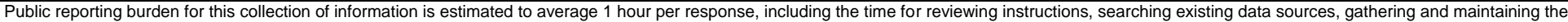

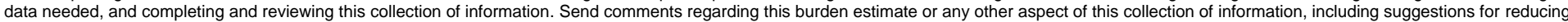

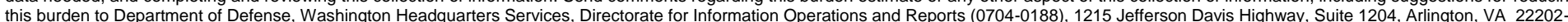

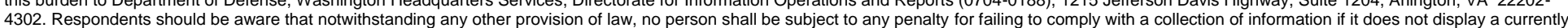
4302. Respondents should be aware that notwithstanding any other provision of law, no person sh
valid OMB control number. PLEASE DO NOT RETURN YOUR FORM TO THE ABOVE ADDRESS.
1. REPORT DATE (DD-MM-YYYY)
2. REPORT TYPE
Final Report

\section{TITLE AND SUBTITLE}

Deconstruction Feasibility Assessment of Warehouse District Facilities at Fort Leonard Wood, Missouri

5a. CONTRACT NUMBER

5b. GRANT NUMBER

5c. PROGRAM ELEMENT

6. AUTHOR(S)

Samuel J. Vance, Thomas A. Carlson, Juan L. Davila-Perez, and Dominique S. Gilbert

\section{5d. PROJECT NUMBER}

5e. TASK NUMBER

5f. WORK UNIT NUMBER

8. PERFORMING ORGANIZATION REPORT NUMBER

\section{PERFORMING ORGANIZATION NAME(S) AND ADDRESS(ES)}

U.S. Army Engineer Research and Development Center (ERDC)

Construction Engineering Research Laboratory (CERL)

2902 Newmark Dr,

Champaign, IL 61822

ERDC/CERL TR-22-1

\section{SPONSORING / MONITORING AGENCY NAME(S) AND ADDRESS(ES)}

Fort Leonard Wood

597 Mascen Loop

Fort Leonard Wood, MO 65473

10. SPONSOR/MONITOR'S ACRONYM(S)

PAIO

11. SPONSOR/MONITOR'S REPORT NUMBER(S)

\section{DISTRIBUTION / AVAILABILITY STATEMENT}

Approved for public release; distribution is unlimited.

\section{SUPPLEMENTARY NOTES}

This work was funded via Military Interdepartmental Purchase Request (MIPR) No. 10773376, "Fort Leonard Wood Water Investigation,” Project A109o, "Net Zero Water."

\section{ABSTRACT}

The U.S. Army Engineer Research and Development Center, Construction Engineering Research Laboratory (ERDC-CERL) and Fort Leonard Wood, MO, are in the sixth year of efforts to plan and implement a program in support of installation sustainability. As part of this effort, ERDC-CERL personnel supported the Fort Leonard Wood Directorate of Public Works (DPW) by conducting a deconstruction assessment of multiple buildings in the warehouse district. The project delivery team visited Fort Leonard Wood in April 2017 to conduct quantity take-offs of the buildings. An abbreviated interim report that focused exclusively on Bldgs. 2338 and 2339 was provided to the Chief, Master Planning Branch, at that time. These two buildings were representative of the majority of the buildings in the assessment and thus became the model that we describe in detail in the sections below. Differences between the other warehouses and the model are discussed. Several buildings that had configurations different from that of the model were evaluated independently.

\section{SUBJECT TERMS}

Military bases--Facility management; Fort Leonard Wood (Mo.); Warehouses-Evaluation; Building materials--Reuse

\section{SECURITY CLASSIFICATION OF:}

\section{a. REPORT}

Unclassified

\section{b. ABSTRACT \\ Unclassified}

17. LIMITATION OF ABSTRACT

\section{c. THIS PAGE}

Unclassified
SAR
8. NUMBER OF PAGES

94 19a. NAME OF RESPONSIBLE PERSON

19b. TELEPHONE NUMBER

(include area code) 